\title{
AECD -3361
}

Handbook on

\section{Air Cleaning}

\section{Particulate Removal}

Prepared by Sheldon K. Friedlander

Leslie Silverman, Philip Drinker

and Melvin W. First
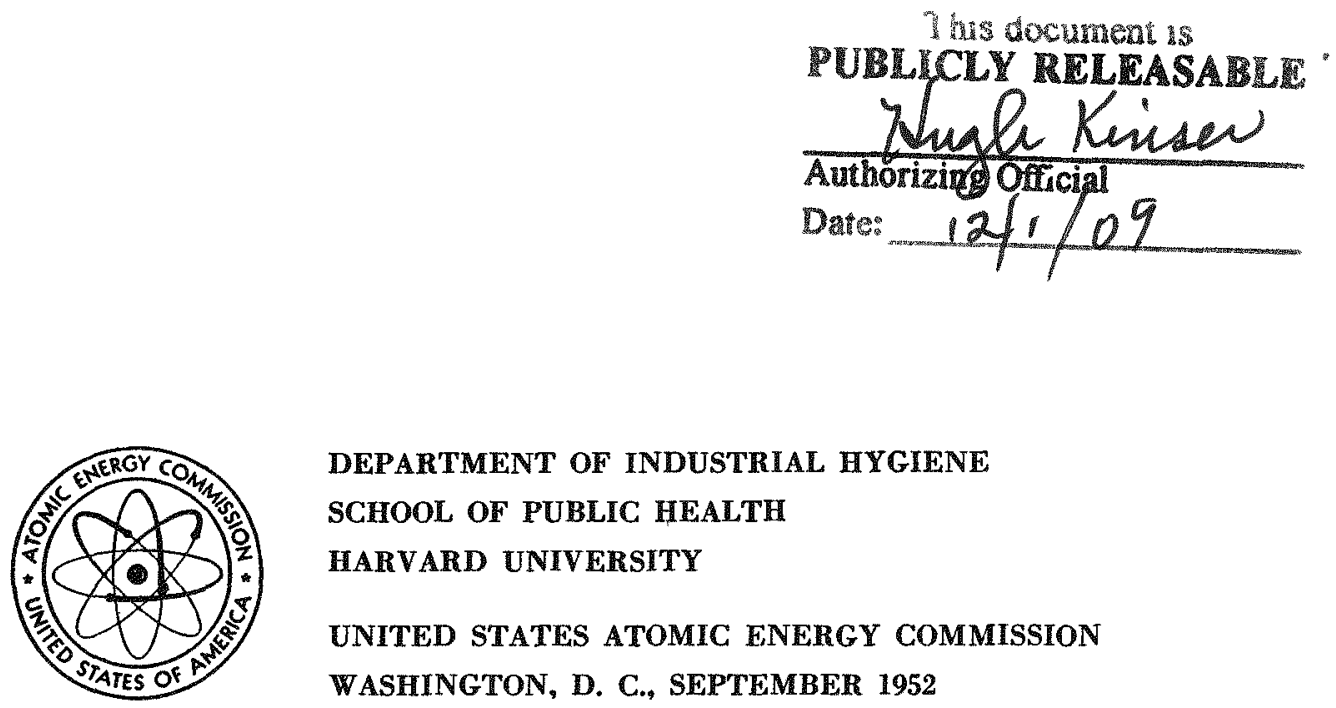

DEPARTMENT OF INDUSTRIAL HYGIENE

SCHOOL OF PUBLIC HEALTH

HARVARD UNIVERSITY

UNITED STATES ATOMIC ENERGY COMMISSION

WASHINGTON, D. C., SEPTEMBER 1952

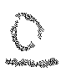

\footnotetext{
For sale by the Superintendent of Documents, U. S. Government Printing Office Washington 25, D. C. - Price 45 cents
} 


\section{DISCLAIMER}

This report was prepared as an account of work sponsored by an agency of the United States Government. Neither the United States Government nor any agency Thereof, nor any of their employees, makes any warranty, express or implied, or assumes any legal liability or responsibility for the accuracy, completeness, or usefulness of any information, apparatus, product, or process disclosed, or represents that its use would not infringe privately owned rights. Reference herein to any specific commercial product, process, or service by trade name, trademark, manufacturer, or otherwise does not necessarily constitute or imply its endorsement, recommendation, or favoring by the United States Government or any agency thereof. The views and opinions of authors expressed herein do not necessarily state or reflect those of the United States Government or any agency thereof. 


\section{DISCLAIMER}

Portions of this document may be illegible in electronic image products. Images are produced from the best available original document. 


\section{TABLE OF CONTENTS}

Page

PREFACE

ii

CHAPTER I

Behavior of Aerosols in Air Cleaning

CHAPTER II

Air Cleaning Equipment

CHAPTER III

Performance and Evaluation of Air Cleaning Equipment

CHAPTER IV

Special Problems Involved in the Cleaning of Radioactive Aerosols

NOMENCLATURE

86

REFERENCES 


\section{PREFACE}

This handbook was written at the request of the Advisory Stack Gas Problem Working Group under the Chairmanship of Dr. Abel Wolman of Johns Hopkins University. Its purpose is to make available to AEC personnel current information on air cleaning methods and criteria for judging their effectiveness. We have limited the discussion to particulate removal and have not attempted to cover the allied fields of ventilation, or of the removal of gaseous contaminants. In preparing the text we have drawn freely from publications of the various AEC installations, from standard journals and commercial literature and from Gibbs, ${ }^{1}$ Whytlaw-Gray and Patterson, ${ }^{2}$ Drinker and Hatch, ${ }^{3}$ Dalla Valle, the Chemical Engineers' Handbook, ${ }^{5}$ and the recently published Handbook on Aerosols. ${ }^{6}$ This source material represents widely different aspects of the problem. In general, the data have been carefully culled in these publications. We have tried not to re-write fundamental material which in our opinion is given satisfactorily elsewhere and is readily available.

One of the purposes of the Air Cleaning Laboratory established recently at Harvard University is to assemble performance data on air cleaning devices. This is the sort of task which should go along with industrial developments. Results need periodic revising and checking. Capacities of equipment, costs, efficiencies and the like are necessarily dated, but the trends indicated by tabulations such as we give warrant their collection in a handbook; the data then can be revised and rewritten as need indicates. We are grateful to the contractors at the AEC sites for their information and comments during the preparation of the manual. We also wish to thank the long list of manufacturers of air cleaning equipment and the many users of such equipment who have answered our letters and questionnaires. Some of them have sent us equipment and many others have allowed us to check performances in the field. 
Chapter 1

\section{BEHAVIOR OF AEROSOLS IN AIR CLEANING}

Aerosols are suspensions of particles in a gaseous medium, usually air. The particulate constituents are dusts, fumes, smokes, and mists. Our objective in air cleaning is the removal of these particulates.

The definitions of the various types of particles occurring in aerosols can best follow conventional usage, and the words should mean about what they mean in ordinary parlance: Dusts are formed by disintegration processes like grinding, crushing, blasting, and drilling. We speak of house dust and saw dust; we dump out dust from the vacuum cleaner; and we have dust collectors for handling dusts from rock crushing. The particles are small replicas of the parent material. Their size will be anything from sub-microscopic to macroscopic. Often they can be separated into sized fractions by screening. When dusts are sold, the specifications are usually by chemical analysis and by screen mesh size-so many percent by weight through $50,100,200$ mesh.

Fumes come from physico-chemical reactions like combustion, sublimation and distillation, and their composition may be different from that of the parent material. Lead fume, zinc oxide, uranium oxide, beryllium oxide, and ferric oxide are typical metallurgical fumes. The particles are generally below 1 micron* and exhibit active Brownian motion. They cannot be sized on screens and are apt to floc-

*One micron is $10^{-4} \mathrm{~cm}$. culate with great vigor. Fumes are usually more uniform than dusts; their size can be changed by varying air mixtures, temperatures, or rates of cooling. Once formed, particle size cannot be changed and once flocculated, the separation and redispersion of the particles are difficult.

Smoke "presupposes a certain degree of optical density". Commonly, it means systems that are organic in origin as smoke from coal, oil, wood, and other carbonaceous fuels. We expect smokes to be dark to jet black. Smokiness of industrial chimneys is gauged by the degree of blackness. Smoke, to the housewife or the city smoke inspector, means black particles which are apt to carry with them oil and grease. Smoke particles compare in size to metallurgical fume and commonly are in Brownian motion.

Mists and fogs result from the disintegration of a liquid or from the condensation of vapor on suitable nucleii. They consist of spherical droplets small enough to float in moderate air currents, and vary considerably in size. If water droplets in air coalesce to about 40 microns, they are apt to precipitate as rain. Mists and fogs remain stable if the vapor pressure of the particles is low or if the gas is saturated.

The aerosol which rises when strong nitric acid is spilled on a wooden floor is generally called "acid fume"'. In our parlance the gas contains an aqueous acid mist plus some nitrogen oxide gases. 
Most aerosols are heterogeneous, i.e., they are composed of particles of many different sizes. Very often, however, the size distribution can be represented by a straight line on logarithmic probability paper (3, p. 149), and the distribution function can be defined in terms of two parameters, viz., the median size (by mass $\mathrm{Mg}^{\prime}$ or by count $\mathrm{Mg}$ ) and the standard geometric deviation $(\sigma \mathrm{g})$ :

$\sigma \mathrm{g}=84.13 \%$ size $50 \%$ size

$$
\begin{gathered}
\left(\mathrm{Mg}^{\prime} \text { or } \mathrm{Mg}\right) \\
=50 \% \text { size }\left(\mathrm{Mg}^{\prime} \text { or } \mathrm{Mg}\right) / 15.8 \% \text { size }
\end{gathered}
$$

A perfectly homogeneous aerosol would have a $\sigma \mathrm{g}$ of unity. The mass median represents that size for which the weight of all larger particles is equal to the weight of all smaller particles; the count median is the size at which half of the particles counted are smaller or larger. The relation between the mass and count medians is given by the expression:

$$
\log \mathrm{Mg}^{\prime}=\log \mathrm{Mg}+6.908 \log ^{2} \sigma g
$$

where $\mathrm{Mg}=$ count median

$$
\mathrm{Mg}^{\prime}=\text { mass median }
$$

In Table 1.1 , we give the mass medians and standard deviations for samples of a number of representative aerosols.

\section{PARTICLE CONDITIONING}

We can distinguish between two types of processes in the removal of particulate matter from air. The first consists in preparing the particles for separation or conditioning them by (1) flocculating or (2) wetting them to make deposition easier by gravity or centrifugal forces or (3) charging them for subsequent electrostatic precipitation. The second process is the actual separation of the conditioned particles from the gas. We shall review each type in turn.

\section{Conditioning by Flocculation}

Small particles in Brownian motion frequently collide. The collisions are inelastic and if the particles are solid, e.g., fumes of lead, zinc oxide, magnesium oxide, and ferric oxide, chainlike aggregates are formed. Liquid particles generally coalesce to a single drop.

The coagulation rate for a homogeneous aerosol composed of spherical particles in still air is given by the following expression:

$$
\begin{aligned}
-(\mathrm{dc} / \mathrm{dt})=(4 \mathrm{RT} / 3 \mu \mathrm{N}) & \\
& \left(1+\mathrm{K}_{\mathrm{me}} \lambda_{\mathrm{m}} / \mathrm{D}_{\mathrm{p}}\right) \mathrm{c}^{2}
\end{aligned}
$$

where $\mathrm{dc} / \mathrm{dt}=$ coagulation rate-particles/ unit volume/unit time

$$
\begin{aligned}
\mathrm{R}= & \text { gas constant } \\
\mathrm{T}= & \text { absolute temperature } \\
\mu & =\text { gas viscosity } \\
\mathrm{N}= & \text { Avogadro's number } \\
\mathrm{K}_{\mathrm{me}}= & \text { correction factor }(1.72 \text { for } \\
& \text { air }) \\
\lambda_{\mathrm{m}}= & \text { mean free path of gas }(0.1 \\
& \text { microns for air }) \\
\mathrm{D}_{\mathrm{p}}= & \text { diameter of particle } \\
\mathrm{c}= & \text { concentration-particles } / \\
& \text { unit volume }
\end{aligned}
$$


Flocculation is especially vigorous for heterogeneous aerosols composed of very small particles at high concentrations. It is promoted by agitation and by high temperatures. No practical methods are known for preventing its occurrence. The phenomenon is of some importance in the conditioning of metallic fume particles before removal in settling chambers or by bag filters.

Table 1.1-Particle Sizes for Some Representative Aerosols

\begin{tabular}{|c|c|c|c|}
\hline Aerosol & $\begin{array}{l}\text { Diameter } \\
\text { mass median } \\
\text { microns }\end{array}$ & \multicolumn{2}{|c|}{$\begin{array}{c}\text { Standard geometric } \\
\text { deviation }\end{array}$} \\
\hline $\begin{array}{l}\text { Water drops from hollow } \\
\text { cone spray nozzle at } 100 \\
\text { psi; } 0.063^{\prime \prime} \text { orifice diameter }\end{array}$ & 1220 & 3.4 & (7) \\
\hline $\begin{array}{l}\text { Hard, close grained shale dust } \\
\text { containing } 29 \% \text { free silica; pro- } \\
\text { duced in a drilling operation in } \\
\text { a hard heading in a coal mine }\end{array}$ & 101 & 3.4 & (8) \\
\hline Flyash & 69 & 2.4 & (9) \\
\hline Sea fog & 38 & 1.6 & $(10)$ \\
\hline Rye flour dust in flour mill & 16 & 1.6 & (11) \\
\hline $\begin{array}{l}\text { Dust from beryllium ore treat- } \\
\text { ment; sample taken } 12^{\prime} \text { from } \\
\text { discharge end of kiln }\end{array}$ & 10 & 2.6 & (12) \\
\hline $\begin{array}{l}\text { Beryllium fluoride }\left(\mathrm{BeF}_{2}\right) \text { fume } \\
\text { from furnace pouring operation; } \\
\text { sample taken } 10^{\prime} \text { from furnace } \\
\text { opening }\end{array}$ & 2.3 & 2.2 & (12) \\
\hline $\begin{array}{l}\text { A tmospheric dust from } 14 \text { U.S. } \\
\text { cities (average) }\end{array}$ & 0.97 & 1.56 & (13) \\
\hline Zinc oxide pigment (a fume) & 0.59 & 1.28 & (14) \\
\hline $\begin{array}{l}\text { Shawinigan acetylene carbon black } \\
\text { longest dimension of individual } \\
\text { particles (electron microscope) }\end{array}$ & 0.087 & 1.55 & (15) \\
\hline Red blood cells* & 7.85 & 1.08 & (16) \\
\hline
\end{tabular}

* While not an aerosol, red blood cells may be used for calibration in microscopy since they are so homogeneous. 
In contrast, rock dusts (consisting of large particles at relatively low concentrations) do not flocculate easily and agitation is of little help. The variation of size with time for a magnesium oxide fume and for a calcium carbonate dust is compared in Fig. 1.1. The flocs which formed as the fume aged were of low density and remained in suspension while the larger dust particles settled rapidly. Thus after about 100 minutes, the size of the fume flocs exceeded that of the calcium carbonate particles.

If an aerosol is exposed to sound waves of high frequency, as from a siren, a substantial amount of agglomeration may be produced. The process is not well understood nor is it possible to calculate accurately the coagulation rate from theory. ${ }^{17,18}$ In general, the particles must be below about 10 microns and their concentration above 1 grain $/ \mathrm{CF}\left(2,300 \mathrm{mg} / \mathrm{m}^{3}\right)$. If the concentration is low, not enough particles are present to permit adequate flocculation, and it is necessary to introduce an inert aerosol such as water mist. Frequencies on the order of $5 / \mathrm{kc}$ sec and sound intensities of about 150 decibels (based on $10^{-16}$ watts $/ \mathrm{cm}^{2}$ ) are required. The process has been tried on a fair sized scale in the carbon black industry ${ }^{19}$ and for collection sulfuric acid fog, ${ }^{20}$ but has still to be established on a firm design basis.

\section{Conditioning by Deposition on Droplets}

Particles are caught on liquid droplets by impaction, by diffusion, and, in some cases, by electrostatic forces. Impaction (p. 11) is most significant for particles larger than about 1 micron. The efficiency of impaction, known as the target efficiency $(\eta+)$, is a function of the dimensionless group $\mathrm{D}_{\mathrm{p}}^{2} \mathrm{~V} \rho_{\mathrm{s}} / 18 \mu \mathrm{D}_{\mathrm{b}}$ as shown in Fig. 1.6 ,

where $\mathrm{V}=$ relative velocity between gas and drop

$\rho_{\mathrm{s}}=$ density of particle

$\mathrm{D}_{\mathrm{b}}=$ diameter of drop

Simple spray washers are not very effective for the removal of atmospheric dust because of the relatively large size of the droplets as compared with the particles. Even with an atomizing nozzle, the many small drops quickly reach a terminal velocity too low to permit effective removal unless large centrifugal forces are applied by whirling the gas. Thus little advantage is gained from introducing droplets smaller than about 50 microns. Calculations by Johnstone and Roberts ${ }^{21}$ indicate that the highest impaction efficiencies in the cyclone scrubber* are obtained with water droplets of about 100 microns.

Diffusion ( $p .12$ ), on the other hand, is significant only for particles smaller than about 0.5 micron. Maximum removal efficiency by diffusion is obtained with very small droplets moving at low velocities.

The wettability of the substance (which depends on the surface tensions of the drop and particle) is important because of its effect on the number of elastic collisions between particles and drops. Hygroscopic substances such as sulfuric acid mists and salt fumes are more easily wetted by water than smokes composed of hydrophobic materials. Many dusts are difficult to wet because of an adsorbed air film.

${ }^{*}$ Centrifugal accelerations were assumed to be 100 times gravity. 


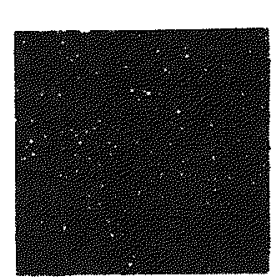

0
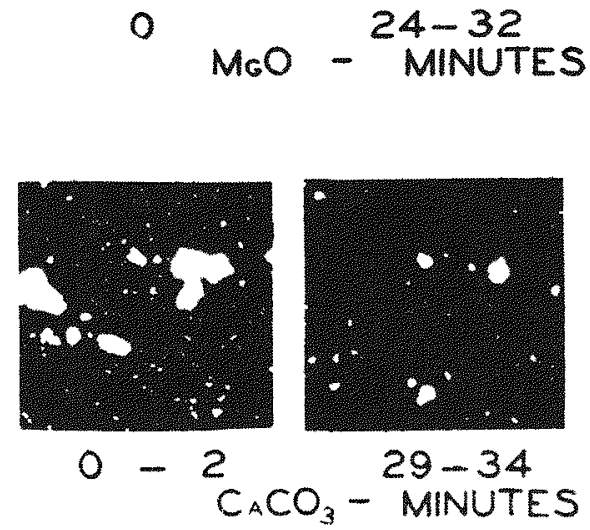

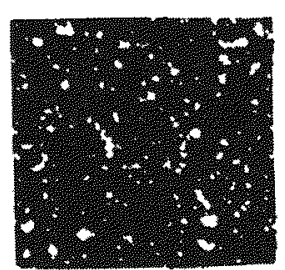

$103-128$

AFTER

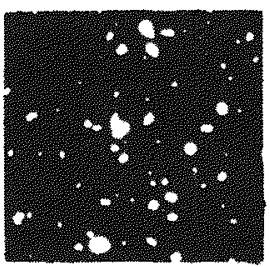

$100-130$

AFTER

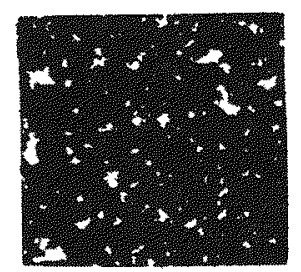

$220-250$

CLOUD FORMATION

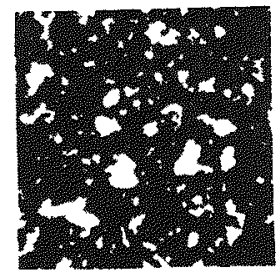

$500-590$

Fig. 1.1-Variation of Size with Time for a Magnesium Oxide Fume and a Calcium Carbonate Dust (Magnification of 173 under Dark Field Illumination)-The largest fume particlesimmediately after formation were about 1.5 microns, but most particles were less than 1 micron. For the calcium carbonate suspension, the mass median was 50 microns and the standard deviation 2.7 at the time of formation. ${ }^{23}$

Particles can also be conditioned by condensing vapor upon them. Here, again, hygroscopic substances work better (the air need not be saturated) and will condense water upon themselves until the vapor pressure on the particle is equal to that in the air. This effect is important in scrubbing if the gases are hot and the particles small. Live steam is also effective although seldom used because of cost.

\section{Conditioning by Charging}

The processes by which particles are charged can be divided into at least four groups: First, the charges may result from a violent process of generation such as an explosion or atomization. Secondly, there may be friction between the particles, with the containing walls, or with the molecules of the gas. Recent work by Kun$\mathrm{kel}^{22}$ indicates that if a mass of dust particles is dispersed by an air blast, practically all of the particles are charged. The charge acquired by a 5 micron $\mathrm{SiO}_{2}$ particle is about 100 electron units. The aerosol as a whole is usually neutral unless it is blown against a surface different from that of the dust during the dispersion process.

Third, the charge may result from collision with or adsorption of gaseous ions and electrons from corona discharge, alpha, beta, or gamma radiation, etc. Corona discharge is the only method used in commercial electrostatic precipitation. 
In the Cottrell precipitator, the discharge terminal is negative, while in the two stage device it is positive. ${ }^{*}$ The aerosol particles gradually assume the polarity of the ions produced at the discharge electrode, but present theory does not permit accurate calculation of the magnitude of the charge. White et al. ${ }^{9}$ state that in a Cottrell precipitator, a 1 micron particle acquires a charge on the order of 200 electron units. For submicron "particles, the charge is proportional to the diameter; for larger particles, it depends on the square of the diameter and is proportional to the strength of the electric field.

Finally, the charge may result from direct irradiation of the particles themselves. Fumes exposed to $\mathrm{X}$-rays were found to contain approximately equal numbers of positive and negative particles (2, p. 163). Charging probably was due both to directirradiation and to collisions with the ions of the gas.

\section{PRECIPITATION}

Whether or not the particles are conditioned, in modern air cleaning equipment they move to the collecting point (fiber surface, baffle plate, chamber wall or floor, etc.) because of (1) gravity, (2) centrifugal or inertial forces, (3) diffusion, (4) electrical forces, and (5) thermal forces. It is not necessary that the conditioning and precipitating processes be carried out separately; more often, the two take place simultaneously. Fig. 1.2

\footnotetext{
*A negative discharge is used in the Cottrell since higher voltages without arcing are possible. The twostage precipitator used in air conditioning employs a positive ionizing section to minimize the formation of ozone.
}

shows how they are applied in various air cleaning devices.

As the particles move through the gas toward a collecting surface, they encounter a resistance resulting from friction with the molecules of the medium. Generally, an equilibrium is reached very rapidly between this resistance and the force producing motion, and the particles assume a constant velocity known as the terminal velocity. The resistance may be expressed in the following manner:

$$
\begin{array}{r}
F_{d}=\left(C \rho u^{2} A_{p}\right) / 2=\left(C \rho u^{2} \pi D_{p}^{2}\right) / 8 \\
\text { (for a spherical particle) }
\end{array}
$$

where $\mathrm{C}=$ drag coefficient (dimensionless)

$\rho=$ density of gas

$\mathrm{u}=$ velocity of particle relative to that of gas

$A_{p}=$ projected area of particle

The drag coefficient $\mathrm{C}$ can be obtained from Fig. 1.3 where it is plottedas a function of the dimensionless group $\mathrm{D}_{\mathrm{p}} \mathrm{\rho} / \mu$ known as the Reynolds number. For most dusts, this value extends from about 0.0001 to 1.0 (corresponding to a range of about 1 to 200 microns for particle diameters). Over this range the drag coefficient is equal to $24 / \mathrm{D}_{\mathrm{p}} \mathrm{u} \rho / \mu$, and by substitution in Eq. 1.4 the resistance of the gas to the movement of a spherical particle is given by Eq. 1.5, known as Stokes' law:

$$
F_{\mathrm{d}}=3 \pi \mu \mathrm{D}_{\mathrm{p}} \mathrm{u}
$$

For submicron particles such as fumes or smokes (Reynolds numbers below 0.0001), the gas ceases to act as a continuous medium, and the particles appear to "slip" between the molecules. As a result, the correction factor proposed by Cunningham must be applied to Stokes' law: 
Fig. 1.2-The Application of Conditioning and Precipitating Effects in Various Air Cleaning Devices

DEVICE *

CONDITIONING

PRECIPITA TING FORCES

Settling
Devices
Inertial or
Centrifugal
Separators

Flocculation (Simultaneous for Fumes)

Gravity

\begin{tabular}{c}
$\begin{array}{c}\text { Flocculation (Simultaneous } \\
\text { for Fumes) }\end{array}$ \\
\hline
\end{tabular}

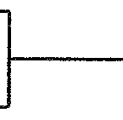

Gravity

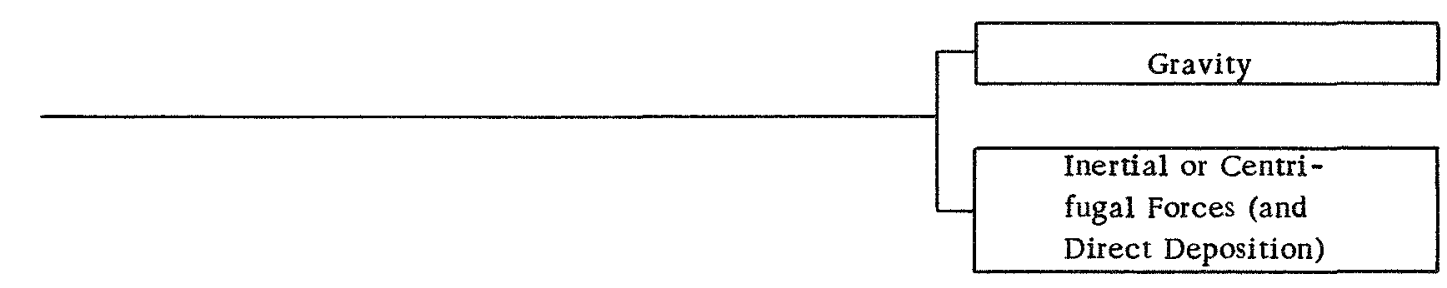

Scrubbers

Deposition on Spray Drop-
lets and Condensation
(Simultaneous)

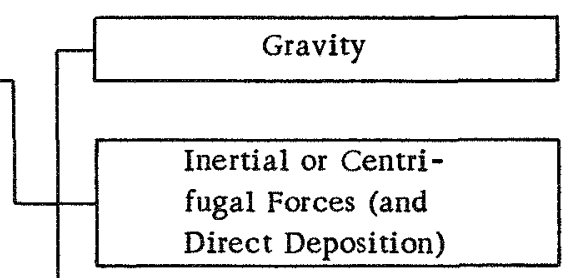

Filters

Flocculation (for Removal
of Fumes by Bag Filters)

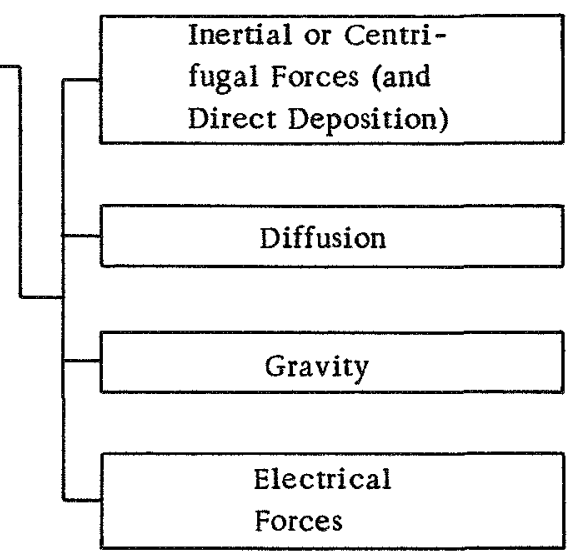

\begin{tabular}{ll} 
Electric & \multicolumn{1}{c}{ Charging (Simultaneous for } \\
Precipitators & Cottrell, Separate for \\
2-stage)
\end{tabular}

Electrical

Forces

\footnotetext{
* Sieving or removal by pores with diameters smaller than the particles is of importance in cloth collectors and in the "molecular" filter (Chap. III, p. 60). In the cloth filter, sieving is performed by the bed of aerosol particles which accumulate on the cloth.
} 


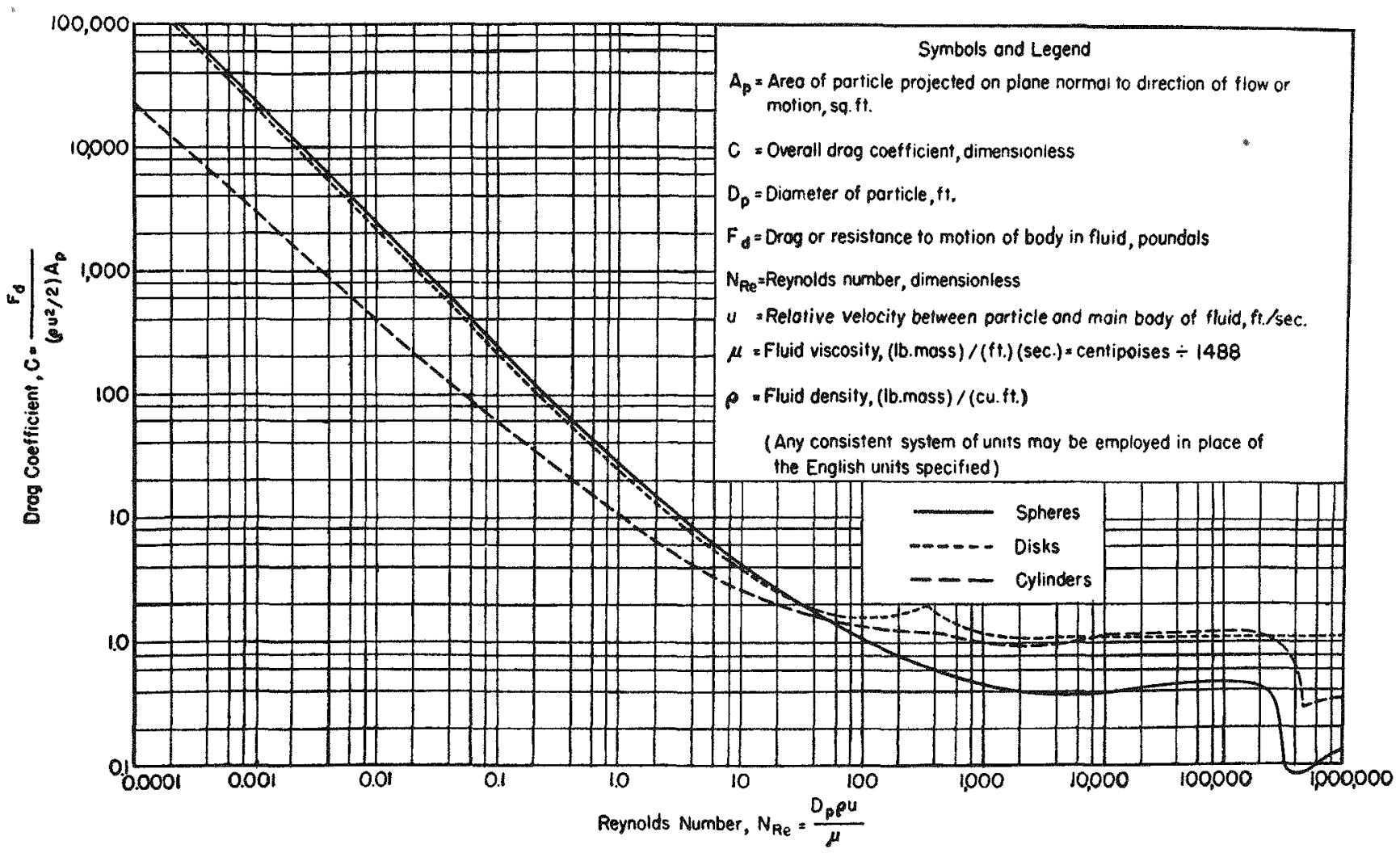

Fig. 1.3-Drag Coefficient vs Reynolds Number for Spheres, Infinite Cylinders, and Discs with Flat Surface Normal to the Direction of Flow. $(5, p .1018)$

$$
\mathrm{F}_{\mathrm{d}}=\left(3 \pi \mu \mathrm{D}_{\mathrm{p}} \mathrm{u}\right) /\left(1+\mathrm{K}_{\mathrm{me}} \lambda_{\mathrm{m}} / \mathrm{D}_{\mathrm{p}}\right)
$$

Stokes' law was derived for spherical particles as of mists or fogs. But in dusts and fumes, the particles may be irregularly shaped, they may be crystalline, or they may be composed of aggregates resulting from flocculation. Usually, little error is introduced by using the diameter of an equivalent sphere for particles differing only slightly from the spherical, e.g., cubes octahedrons, or other polyhedral crystals. On the other hand, a considerable error may result with needles, plates, or chainshaped flocs. Table 1.2 gives values for the diameters which should be substituted in Stokes' law for prolate spheroids (produced by revolving an ellipse around its longer axis) and compares them with the diameter of an equivalent sphere. For a thin disk-like particle with its flat surface normal to the direction of flow, the drag coefficient and equation of resistance can be obtained from Fig. 1.3. Waddel ${ }^{24}$ also gives drag coefficients as a function of Reynolds number for bodies of various shapes. These non-spherical particles move through a gas in the position in which they encounter maximum resistance, e.g., a cube settles with point downward and a 
plate or disk in a horizontal position.

In settling and in deposition by inertial forces, the particle density $\left(\rho_{\mathrm{s}}\right)$ is an important variable. For mists and fogs which coalesce to form spheres, $\rho_{s}$ and the normal density of the original liquid are about the same. For aerosols made up of flocs of fume particles, however, $\rho_{\mathrm{s}}$ may be considerably less than the normal density.

Table 1.2-Stokes' Law Diameters for Prolate Spheroids $(2$, p. 98)

\begin{tabular}{cccc} 
Ratio of & \multicolumn{2}{c}{ Diameter* for } & Diameter of \\
axes & motion parallel to & $\begin{array}{c}\text { Diam } \\
\text { equivalent } \\
\text { sphere }\end{array}$ \\
$2: 1 \dagger$ & 2.40 & 2.76 & 2.52 \\
$3: 1$ & 2.82 & 3.46 & 2.88 \\
$4: 1$ & 3.20 & 4.12 & 3.18 \\
$5: 1$ & 3.56 & 4.74 & 3.42 \\
$6: 1$ & 3.94 & 5.36 & 3.64
\end{tabular}

* Minor axis two units long.

†This corresponds to a floc formed by the coagula tion of two spherical particles of equal diameter.

Table 1.3-Particle Densities for Flocs* (2, pp. 96, 107)

$\begin{array}{ccl} & \text { Floc } & \text { Normal } \\ \text { density } & \text { density } \\ \text { Material } & \text { gms/cc } & \text { gms/cc }\end{array}$

$\begin{array}{lcc}\text { Silver } & 0.94 & 10.5 \\ \text { Mercury } & 1.70 & 13.6 \\ \text { Cadmium oxide } & 0.51 & 6.5 \\ \text { Magnesium oxide } & 0.35 & 3.65 \\ \text { Mercuric chloride } & 1.27 & 5.4 \\ \text { Arsenic trioxide } & 0.91 & 3.7 \\ \text { Lead monoxide } & 0.62 & 9.36 \\ \text { Antimony trioxide } & 0.63 & 5.57 \\ \text { Aluminum oxide } & 0.18 & 3.70 \\ \text { Stannic oxide } & 0.25 & 6.71\end{array}$

*Excludes particles of normal density.
Mean densities for aggregates of several materials are given in Table 1.3. These figures are statistical averages, and the densities of individual flocs may vary considerably with the packing and with the size of the original particles.

\section{Settling by Gravitational Forces}

Terminal settling velocities can be calculated from the equations given in Fig. 1.4 which were obtained by equating the force of gravity to the frictional resistance and buoyant force of air. Table 1.4 gives the settling velocities in air of spherical particles of various sizes but unit density.

\begin{tabular}{|c|c|}
\hline $\begin{array}{c}\text { Diamerer of particle } \\
\text { microns }\end{array}$ & $\begin{array}{c}\text { Terminal } \\
\text { settling velocity } \\
\mathrm{ft} / \mathrm{sec}\end{array}$ \\
\hline 0.1 & 0.0000027 \\
\hline 1.0 & 0.00012 \\
\hline 10.0 & 0.01 \\
\hline 100.0 & 1.0 \\
\hline
\end{tabular}

Settling is important in air cleaning only for particles larger than about 10 microns. Smaller particles settle so slowly that slight convection currents prevent sustained downward motion. Obviously low gas velocities are favorable to settling since more time is permitted for the par ticles to fall to the collecting surfaces.

\section{Deposition by Centrifugal or Inertial Forces}

When the path of an aerosol is changed, 


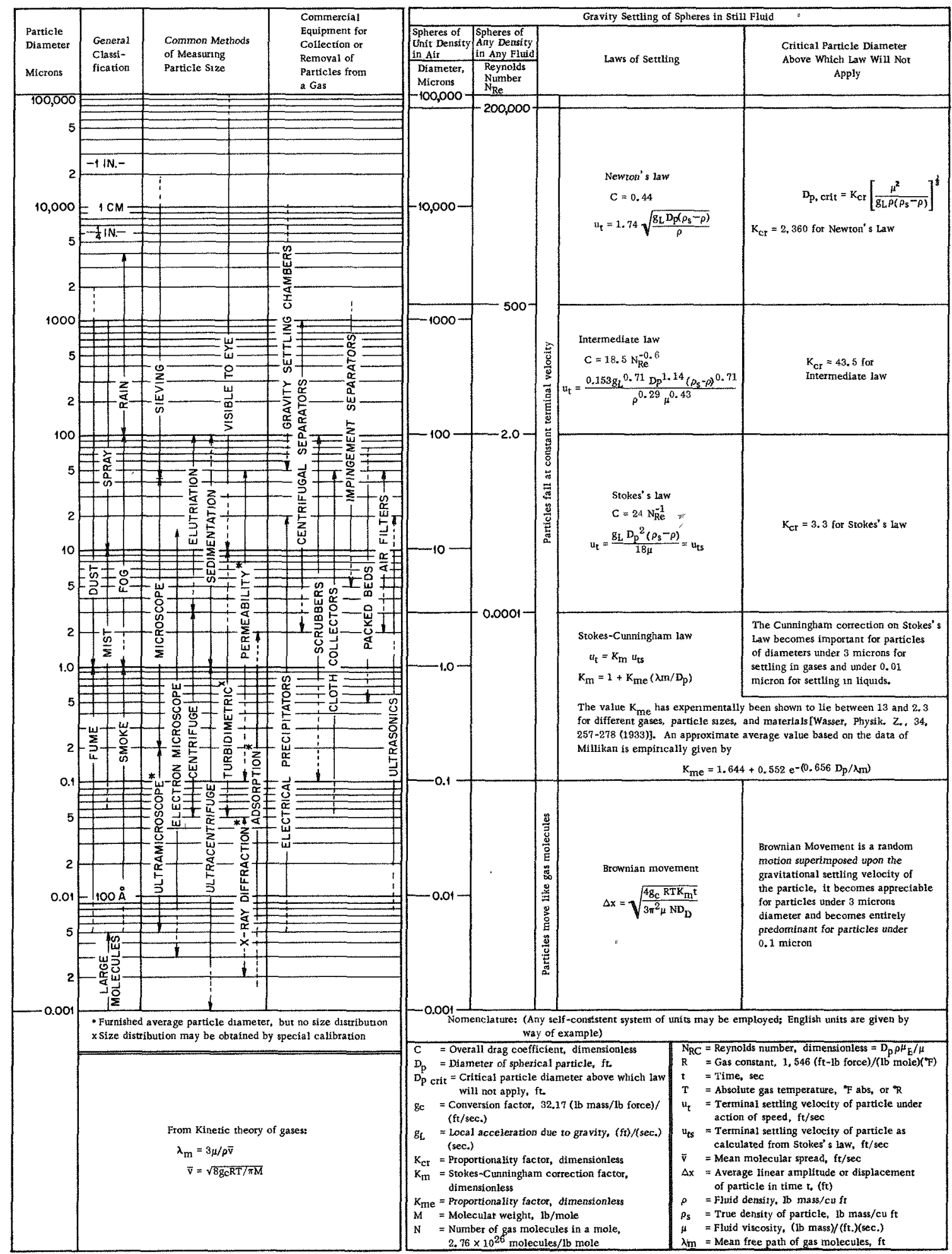

Fig. 1.4-Characteristics of Air-borne Particles, (5, p. 1019) 
the particles, because of their inertia, tend to continue in their original direction and can be caught on a collecting surface. Looking at it in another way, the particles are thrown from the gas by centrifugal forces. This effect is utilized in cyclone separators, baffle chambers, fibrous filters, and wet collectors. In the cyclone, the gas makes several complete revolutions before it leaves the apparatus while in the other equipment, it only bends around baffle plates, fibers, and water droplets, respectively, and then continues in its original direction.

The radial velocity of a particle in a centrifugal force field is given by the following expression, obtained by equating the centrifugal force to the Stokes' resistance:

$$
u=\left(D_{p}^{2} \rho_{s} V_{L}^{2}\right) /\left(18 \mu R_{c}\right)
$$

where $V_{L}=$ tangential velocity of the gas stream

$$
R_{c}=\text { radius of curvature of }
$$
gas stream

Separation by centrifugal forces is important in air cleaning only for large, heavy particles as of dusts or mists greater than about 1 micron.* Small particles with little inertia are carried along with the gas. Removal is favored by high gas velocities and by sudden changes in direction (small $R_{c}$ ); for this reason, $c y-$ clones with small diameters are more efficient than larger ones (Chap. II, p. 21).

Impaction, as on a filter fiber or a water droplet, is an inertial effect. The impac-

*This is true for particles with densities of about $1 \mathrm{gm} \mathrm{cc}$. It is possible, however, to separate effectively by inertial forces submicron particles of much heavier substances, e.g., $\mathrm{UO}_{2}$ with a $\rho_{\mathrm{S}}$ of 10.9 . tion or target efficiency $\left(\eta_{+}\right)$is defined as the fraction of particles of a given size which strikes the collecting surface in the volume swept out by the surface. For flow around a cylindrical fiber, as shown in Fig. 1.5 all particles initially between the streamlines A and B will hit the body, and the target efficiency is $X / D_{b}$. When Stokes' law is applicable to the motion of the particles, $\eta_{+}$is a function of the dimensionless group $D_{p}^{2} V \rho_{s} / 18 \mu D_{b}$ known as the separation number, where $D_{b}$ is the characteristic dimension of the obstacle; this relationship is shown for cylinders, spheres, and ribbons in Fig. 1.6. It is evident that in filtration by beds of comparable densities, the highest impaction efficiencies will be obtained with the filters composed of the finest fibers.

The composite or gradient glass wool filter (Chap. II, p. 39) is made by placing coarse pads of glass fibers at the gas inlet and progressively increasing the packing density while decreasing the diameter of the fibers. Even though the fibers at the inlet are thick, impaction efficiency for large particles is high (high $D_{p}$ ). The smaller particles are caught by the finer fibers (low $D_{b}$ ). Deposition of very small particles by diffusion is favored by the large surface areas associated with the fine, densely packed fibers. Thus a properly made gradient filter will provide both high efficiency and large storage capacity (long life).

Particles which would be expected to follow the gas streamlines around the target $\left(\eta_{+}=0\right)$ may touch because their radius is greater than the distance from the streamline to the surface. This effect is known as direct deposition or direct interception. 


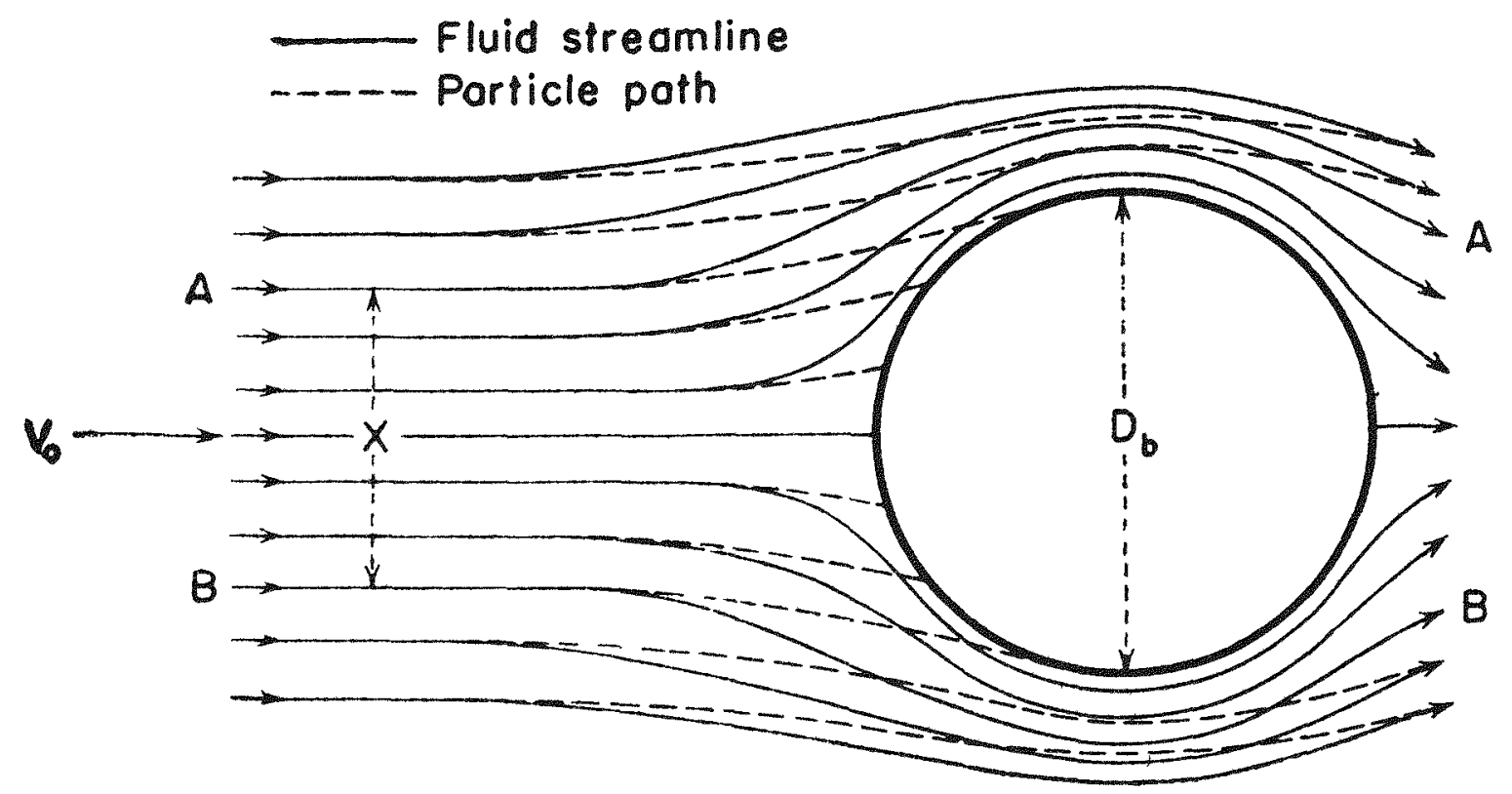

Fig. 1.5-Impaction of Particles on a Cylinder-Target Efficiency $=X / D_{b} \cdot(5, p .1022)$

\section{Deposition by Diffusion}

If a concentration gradient exists in an aerosol, particles tend to diffuse from the region of higher to that of lower concentration until uniform distribution is obtained. * Thus in filtration, particles diffuse from the gas main stream to the fibers since the concentration of particles at the fiber surfaces is zero (assuming no inelastic collisions). In the conditioning of particles by a liquid spray, the droplet surfaces are regions of zero concentration. The rate of diffusion is given by the following expressions, assuming the air resistance is given by the Stokes-Cunningham law:

*Uniform vertical distribution is prevented by gravity since the particles tend to concentrate at the bot tom of the system (provided convection currents are absent).

$$
\mathrm{dn} / \mathrm{dt}=-\mathrm{D}(\mathrm{dc} / \mathrm{dx}) \mathrm{A}=-(\mathrm{RT} / 3 \mu \mathrm{N} \mathrm{D} \mathrm{p})
$$$$
\left(1+K_{m e} \lambda_{m} / D_{p}\right)(d c / d x) A
$$

where $\mathrm{dn} / \mathrm{dt}=$ diffusion rate-particles $/$ unit time

$\mathrm{D}=$ diffusivity - Table 1.5 gives values for $\mathrm{D}$ in air at $25^{\circ} \mathrm{C}$

$A=$ cross sectional area of diffusion

$\mathrm{dc} / \mathrm{dx}=$ concentration gradient particles/unit volume/unit length of path

Diffusion is favored by low gas velocities past the collecting surfaces and is rapid for small particles and high concentration gradients. In most air cleaning devices, it is significant only for small dust par- 


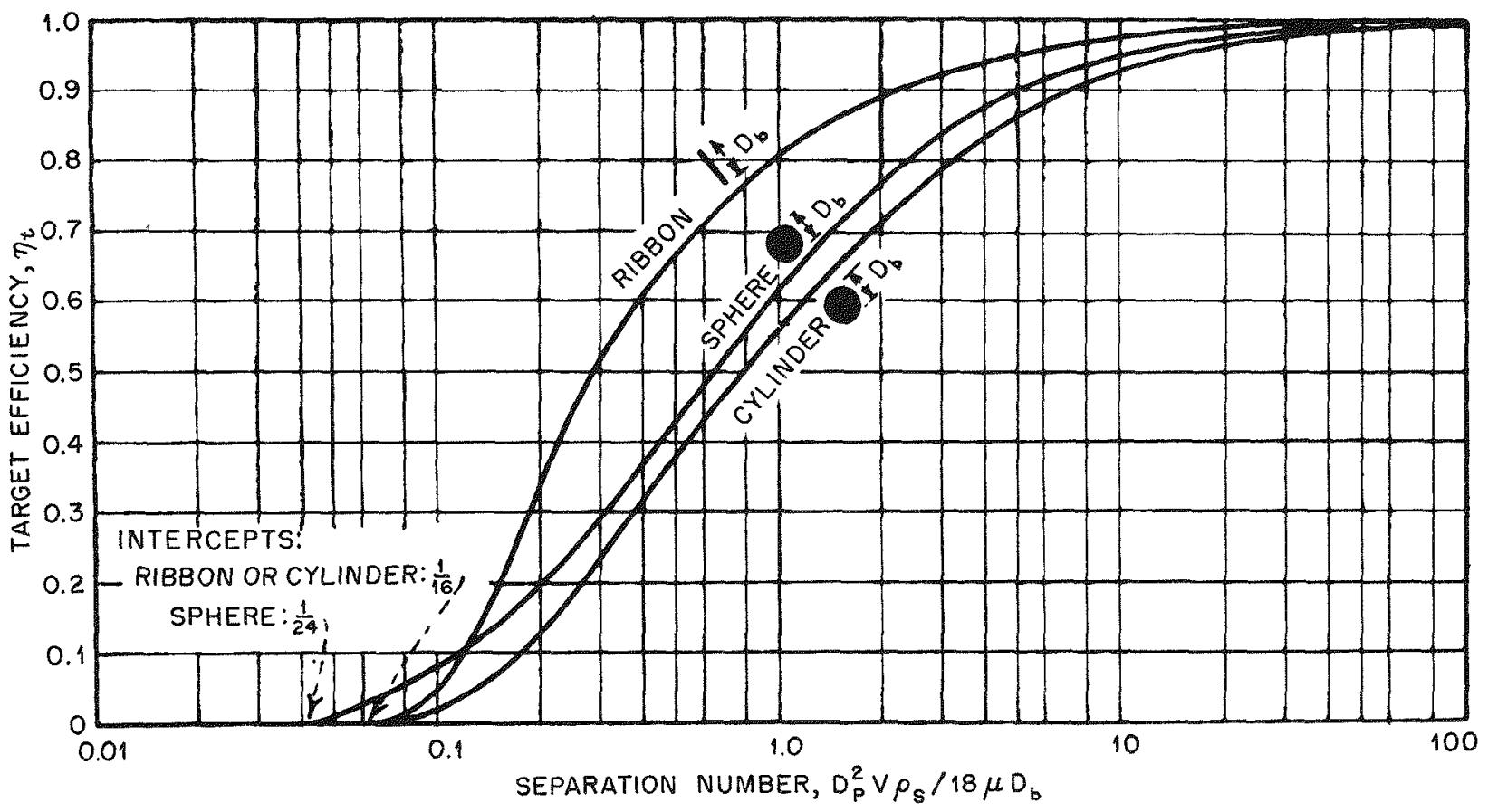

Fig. 1.6-Target Efficiency vs Separation Number for Ribbons, Spheres, and Cylinders - These curves were developed for ideal flow around the target. $(5, \mathrm{p}, 1022)$

Table 1.5-Diffusivities of Particles in Air at $25^{\circ} \mathrm{C}$ (21, p. 2419)

$\begin{array}{cc}\begin{array}{c}\text { Particle diameter, } \\ \text { microns }\end{array} & \begin{array}{c}\mathrm{D} \\ \mathrm{cm}^{2} / \mathrm{sec}\end{array} \\ 0.5 & 6.4 \times 10^{-7} \\ 0.1 & 6.5 \times 10^{-6} \\ 0.01 & 4.4 \times 10^{-4} \\ \mathrm{SO}_{2} \text { molecules } & 11.8 \times 10^{-2}\end{array}$

ticles or smokes or fumes less than about 0.5 micron in diameter. It should be noted that the diffusion rate is independent of the density of the particle.

\section{Precipitation by Electrical Forces}

Electric precipitation, in addition to its use per se in air cleaning, may also contribute significantly to filtration, although its effect in this process is notwell understood. In commercial electric precipitators, a DC field is used. The velocity with which a particle moves toward a collecting electrode (the migration velocity) can be obtained from the following expression, assuming the air resistance is given by the Stokes-Cunningham law:

$$
\mathrm{u}=(\mathrm{Ee})\left(1+\mathrm{K}_{\mathrm{me}} \lambda_{\mathrm{m}} / \mathrm{D}_{\mathrm{p}}\right) /\left(3 \pi \mu \mathrm{D}_{\mathrm{p}}\right)
$$


where $E=$ strength of the field

$\mathrm{e}=$ charge on the particle

Migration velocities for flyash (most particles between 1 and 10 microns) obtained from field data are on the order of $20 \mathrm{~cm} /$ sec. ${ }^{9}$ Since the charge acquired by a submicron particle is proportional to its diameter, the migration velocity, and consequently, efficiency of removal for small particles is nearly independent of size.* A particle larger than about 1 micron, on the other hand, picks up a charge proportional to the square of its diameter; its migration velocity depends on its diameter and large particles are removed more readily than small ones. This is true under controlled laboratory conditions, but in practice, re-entrainment by the gas stream reduces removal efficiency for the larger particles; specially designed collecting plates are used to minimize this effect.

For particles above 1 micron, $u$ depends on the square of the field strength and is approximately proportional to the power input. Consequently, common practice has been to operate at the maximum voltage possible without arcing since arc-

\footnotetext{
*For very small particles (less than about $0.2 \mathrm{mi}$ crons) the Cunningham correction factor will become large enough to cause an increase in $u$ with decreasing diameter.
}

ing usually results in lowered efficiency. White et al. ${ }^{9}$ (p. 878), however, have found that the highest efficiencies for flyash are obtained substantially above the sparking point.

If the particles are poor conductors of electricity (as, for example, dry lead fume) an insulating layer accumulates on the collecting electrode. The last particles to deposit retain their charges, tend to nullify the collecting field, and hinder further precipitation. This effect is minimized by humidifying the gas or by adding some other substance which will increase the conductivity of the dust layer.

\section{Deposition by Thermal Forces}

Carbon black has long been produced on a huge scale by burning gas in a rich mixture and letting the products of combustion flow against cold iron channels. Carbon is deposited and scraped off. Such thermal deposition depends upon the temperature gradient between the gas and the collector. If the gradient is sufficiently large, the collecting efficiency can be high. ${ }^{25}$ The thermal precipitator (Chap. III, p. 54), so much used in England for sampling fine dusts in air, is very efficient and depends on this principle. In commercial air cleaning, however, we doubt if the method has any application. 
Chapter II

\section{AIR CLEANING EQUIPMENT}

Much work is in progress on the development of suitable air cleaning equipment for the control of radioactive aerosols and of common industrial suspensions. In this chapter, we shall review devices in current use, emphasizing those which are particularly applicable to the AEC's problems. Such devices fall into the following classes:

(1) Settling chambers

(2) Centrifugal or inertial separators
a) Cyclones
b) Baffle chambers

(3) Scrubbers and other wet collectors
a) Air washers
b) Wet filters
c) Spray towers
d) Centrifugal or inertial scrubbers
e) Venturi scrubbers

(4) Filters
a) Air conditioning filters-viscous and dry
b) Cloth filters
c) High efficiency filters

(5) Electric precipitators-Cottrell and two stage

These classifications are arbitrary because, for example, the installation of water sprays in a simple settling device or cyclone may change the collection method to scrubbing while the insertion of baffles changes a settling chamber into an inertial type.

In Table 2.1, we compare cleaning efficiencies, concentrations handled, pres- sure drops, and air velocities for the various devices. In Chapter III, such comparisons are given in much greater detail for a considerable number of cleaners tested at our Laboratory and in the field.

The loadings handled by the different collectors vary widely. For normal air, concentrations on the order of 1 grain/ $1000 \mathrm{CF}\left(2.3 \mathrm{mg} / \mathrm{m}^{3}\right)$ are found, as shown in Table 2.2. In AEC plants, due to precleaning of the entering air, aerosols are often encountered with concentrations as low as $10^{-5}$ or $10^{-6}$ grains/CF. On he other hand, loadings of some industrial gases may reach several hundred grains per cubic foot, although values of 20 grains/CF $\left(50,000 \mathrm{mg} / \mathrm{m}^{3}\right)$ or less are more common.

\section{SETTLING CHAMBERS}

These are the simplest of the collectors. The most common form is a long box-like structure, set horizontally, often on the ground. The balloon flues leading to bag houses in metallurgical plants serve both for settling and for cooling. They may be equipped with sprays for additional cooling in hot weather, and with drags, screw conveyors, scrapers, and rapping devices.

The settling rooms or "kitchens" used for collecting arsenic trioxide may run at temperatures of 500 to $600^{\circ} \mathrm{F}$, balloon flues at 300 to 400 , and breechings of power plants at about that same temperature. In contrast, the settling chambers in which 
Table 2.1 - Generalized Figures for Performance of Air Cleaning Equipment

\begin{tabular}{|c|c|c|c|c|c|}
\hline Device & $\begin{array}{c}\text { Aerosol } \\
\text { concentrations } \\
\text { handled } \dagger\end{array}$ & $\begin{array}{l}\text { Efficiency, } \\
\%\end{array}$ & $\begin{array}{l}\text { Smallest particle } \\
\text { efficiently separated, } \\
\text { microns }\end{array}$ & $\begin{array}{l}\text { Resistance, } \\
\text { inches of } \\
\text { water }\end{array}$ & $\begin{array}{l}\text { Velocity, } \\
\text { FPM }\end{array}$ \\
\hline Settling chambers & high & & 50 & $1.5-2.0$ outlet pipe & 600 \\
\hline $\begin{array}{l}\text { Howard chamber } \\
\text { Centrifugal or inertial separators }\end{array}$ & high & & 10 & & \\
\hline cyclones & high & $50-90$ (weight) $^{*}$ & $5-10$ & $<4$ & $2500-3000$ (inlet) \\
\hline Baffle chambers & high & & $10-20$ & varies & widely \\
\hline \multicolumn{6}{|l|}{ Washers and scrubbers } \\
\hline Air washers & low & low & 5 & $0.1-0.5$ & 300 (chamber) \\
\hline Wet filters & low & low & 5 & 0.35 & 300 (face) \\
\hline Spray towers & high & varies widely & 5 & varies widely & \\
\hline Centrifugal or inertial scrubbers & high & varies widely & 1 & \multicolumn{2}{|c|}{ varies widely } \\
\hline Venturi scrubbers & high & $>90$ (weight) & submicron & $>10-15$ & $\begin{array}{l}12,000-24,000 \\
\text { (throat) }\end{array}$ \\
\hline \multicolumn{6}{|l|}{ Filters } \\
\hline Viscous & low & $\begin{array}{l}85 \text { (weight) for } \\
\text { particles }>10 \text { microns }\end{array}$ & 1 & $\int \begin{array}{l}0.05-0.30 \\
\text { when clean }\end{array}$ & $300-500$ (face) \\
\hline Dry & low & \multicolumn{2}{|c|}{$\begin{array}{l}\text { from values similar to viscous to } 85 \text { (discoloration) } \\
\text { for submicron particles }\end{array}$} & {$\left[\begin{array}{l}0.4-0.5 \\
\text { when dirty }\end{array}\right.$} & $30-60$ (face) \\
\hline Cloth & high & $>99$ (weight) & submicron & $1-6$ & $0.5-30$ (face) \\
\hline High efficiency & low & $>99$ (count $)^{*}$ & submicron & $1-6$ & $5-20$ (face) \\
\hline Electric precipitators & & & & & \\
\hline Single stage & high & $90-99$ (weight) & submicron & $0.25-1.0$ & $180-600$ \\
\hline Two stage & low & $85-90$ (discoloration) $^{*}$ & submicron & $0.1-0.2$ & $300-500$ \\
\hline
\end{tabular}

* Appraisal methods are discussed in Chapter III.

†By low is meant concentrations on the order of normal air (Table 2.2) and lower; high refers to loadings of about 1 grain/CF and greater. 
Table 2.2-Dust Concentrations in Normal $\mathrm{Ain}^{26}$

$$
\text { Location Grains/1000 } \mathrm{CF}^{*}
$$

Rural and suburban districts

$0.02-0.2$

Metropolitan districts

$0.04-0.4$

$0.1-2.0$

$0.2-4.0$

Ordinary factories or workrooms liter.

*1 grain $/ 1000 \mathrm{CF}=2.3 \mathrm{mg} / \mathrm{m}^{3}=2.3$ micrograms/

powdered milk is collected are operated at ordinary room temperatures or even less.

Various constructional modifications have been tried from time to time, all designed to minimize eddy currents and prolong residence time in the settler. Examples are wires, pipes, and wide mesh screens strung across the chambers. The Howard dust chamber (Fig. 2.1) has shelves which add settling area and increase efficiency. It is claimed that this device handles successfully iron oxide fumes from the burning of pyrites.

In general, it is not practicable to catch in settlers particles of sub-sieve size (less than 40 microns ${ }^{*}$ ). However, fine materials such as carbon black and various metallurgical fumes may flocculate into clumps which have enough mass to permit a certain amount of collection in settling devices.

Ideally, the efficiency of a settling chamber is given by the following expression:

$$
\begin{aligned}
& \eta=\left(\mathrm{N}_{\mathrm{s}} \mathrm{uL} / \mathrm{Hv}\right) 100= \\
& \left(\mathrm{N}_{\mathrm{s}} \mathrm{uBL} / \mathrm{Q}\right) 100 \quad(\eta \leqslant 100)
\end{aligned}
$$

*The Howard chamber may be satisfactory for particles as small as 10 microns.

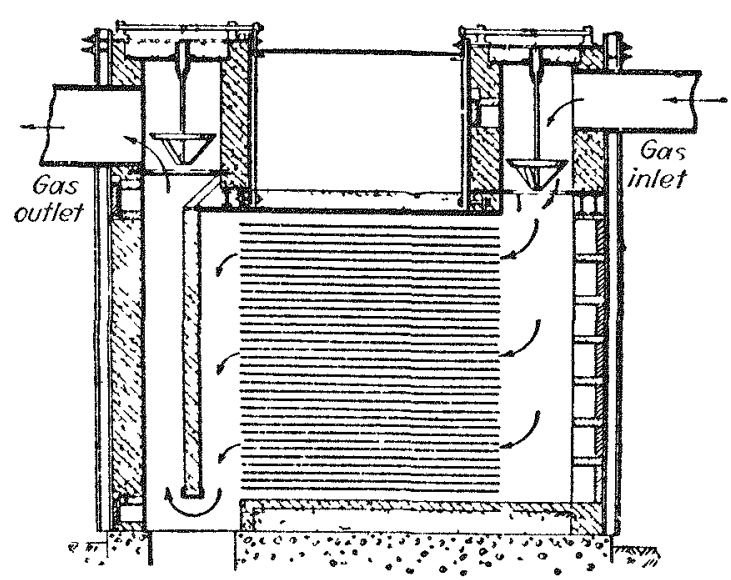

Fig. 2.1-Howard Dust Chamber (5, p. 1022)

where $\mathrm{N}=$ number of shelves $=1$ for simple chamber

$u=$ terminal settling velocity of particle

$\mathrm{L}=$ length of chamber

$\mathrm{H}=$ height of chamber

$\mathrm{v}=$ gas velocity

$\mathrm{B}=$ width of chamber

$Q=$ volumetric flow rate

In practice, however, eddy currents generally hinder precipitation, and a better estimation is obtained ${ }^{27}$ by multiplying $\mathrm{Eq}$. 2.1 by 0.5 .

Illustrative example, 2.1:

Suppose $5000 \mathrm{CFM}$ of a heterogeneous aerosol (particles having unit density) are passing through a simple settling chamber 10 feet wide and 20 feet long. What are the removal efficiencies for the 1,10 , and 100 micron particles, respectively? From Eq. 2.1 (multiplied by 0.5 ) and the terminal velocities of Table 1.4 , Chap. I: 


$\begin{array}{cc}\begin{array}{c}\text { Diameter, } \\ \text { microns }\end{array} & \begin{array}{c}\text { Efficiency, } \\ \text { weight } \%\end{array} \\ 1 & 0.014 \\ 10 & 1.2 \\ 100 & 100\end{array}$

Although the efficiency of the settling chamber is low for small particles, its capacity is very great. Consequently, it is an important preliminary or primary cleaner. Often it can handle cheaply and adequately the great bulk of material to be collected, leaving the final clean-up to devices of lower capacity but greater efficiency.

\section{CENTRIFUGAL OR INERTIAL SEPARATORS}

This group includes cyclones and baffle chambers - devices in which suspended matter is separated from the conveying gas stream by abrupt directional change. These collectors are seldom effective for particles smaller than 5 or 10 microns, but they can be used for hot or cold gases and have a very wide range in capacity. They may be operated at high inlet velocities (several thousand FPM) since efficiency increases with the gas rate.

\section{Cyclones}

The cyclone consists of a cylinder, up to 15 or 20 feet in diameter, with an inverted cone attached to the base (Fig. 2.2). The gas enters tangentially and spirals downward toward the point of the cone. A considerable centrifugal force is thus applied to the particles, which move to the

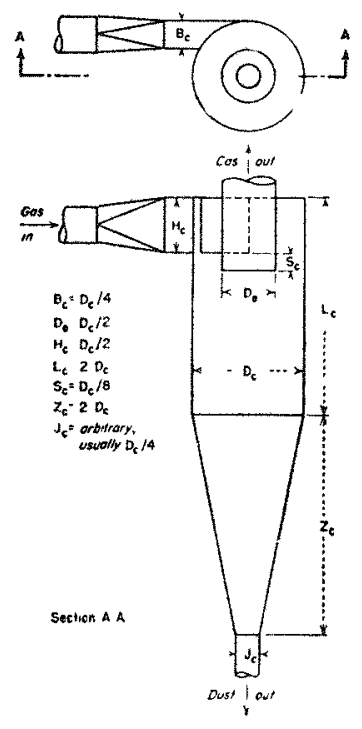

Fig. 2.2-Typical Cyclone Design Proportions (5, p. 1024)

wall and fall to the bottom of the cone and thence into a collecting hopper. The cleaned gases escape through a tube set axially and extending some distance down into the cylinder.

Cyclones are used extensively as primary separators for dusts from rock crushing, ore handling, wood-working, and sand conditioning in foundries. They are not adapted to the collection of fine metallurgical fume, dispersed or flocculated. They handle gas volumes ranging from about 30 to $25,000 \mathrm{CFM}$ and at a very wide range in temperatures. For them to work well, their dust loadings must be high, generally over 10 grains/CF $\left(23,000 \mathrm{mg} / \mathrm{m}^{3}\right)$.

Particle size is fairly critical. If the particles are large (5 to 200 microns), the chances are that a properly designed cyclone will perform a creditable job with moderate power requirements. Most of 
the smaller particles will pass through the device unaffected, and the greater the fraction of these small particles the poorer the separator's performance. For collecting particles larger than 200 microns, a settling chamber is usually better and is more resistant to abrasion.

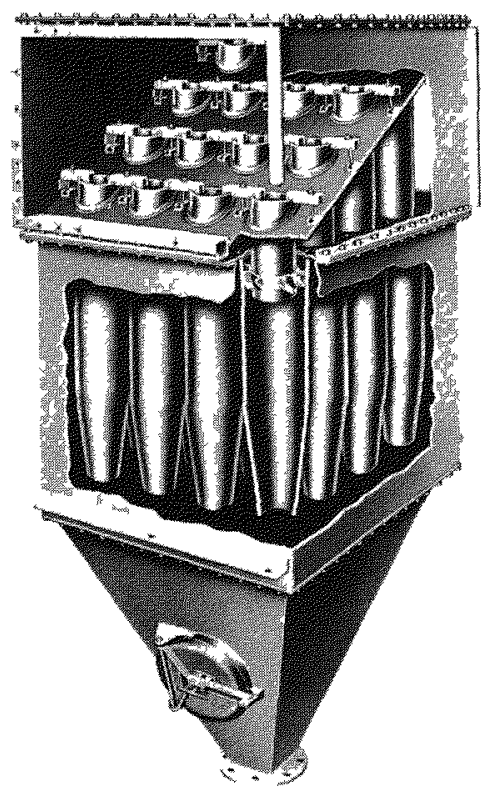

Fig. 2.3-Multuclone (Western Precipitation Corp.)

A recent design of cyclones uses banks of small collectors in parallel. Diameters are a fraction of a foot as contrasted with several feet for the large separators. Small cyclones, although more efficient than large, are of low capacity so that multiple units are necessary. The Multiclone (Fig. 2.3) consists of groups of 6 or 9 inch collectors. Instead of a tangential inlet duct, whirling motion is imparted to the gas by annular vanes (Fig. 2.4) between the outlet duct and cyclone wall. These vanes aid in directing the air stream and also reduce the pressure drop by decreasing the inlet velocity.

The dust may be concentrated before it reaches the cyclone by passing it through

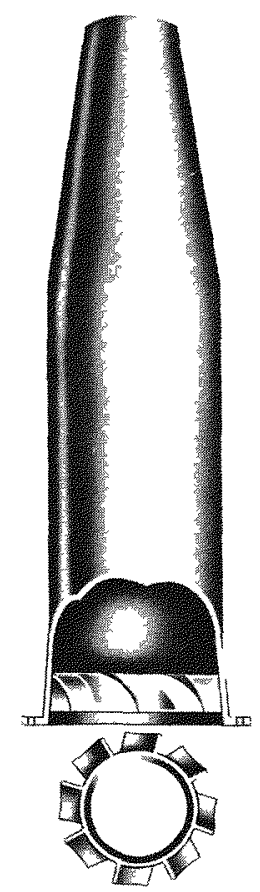

Fig. 2.4-Multiclone Tube Showing Inlet Vanes (Western Precipitation Corp.)

a conical tube with serrated openings known as the Aerodyne Cone (Figs. 2.5 and 2.6). The dust enters the wider end with a velocity of about 3600 FPM. Most of the gas is drawn off through the slits in the side while the concentrated dust passes to a cyclone at the exit. This arrangement permits the use of a smaller cyclone than would be possible with the 
original gas volume. The Sirocco Type D (Fig. 2.7) has an exit duct fitted with an adjustable collar which controls efficiency and pressure drop. Other variations of the cyclone are described by Lapple. ${ }^{5}$

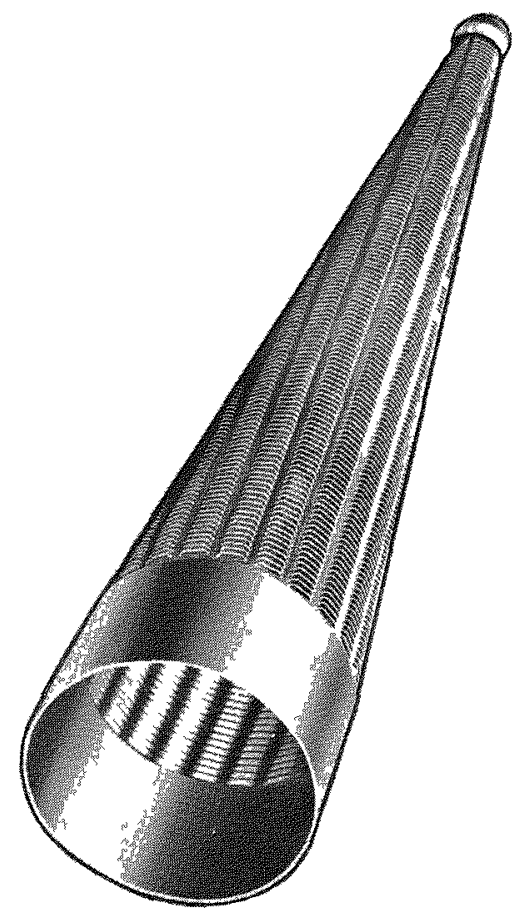

Fig. 2.5- Aerodyne Cone (Aerodyne Atlantic Corp.)

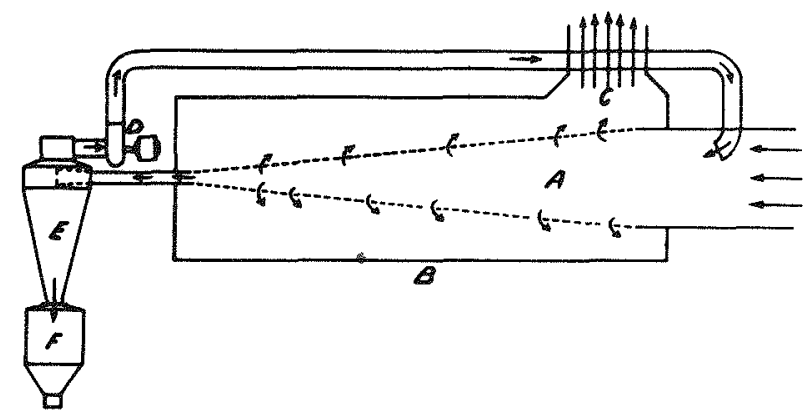

Fig. 2.6-Aerodyne-Cyclone Installation (Aerodyne Atlantic Corp.)
The Type D Rotoclone, another type of centrifugal dust separator (Fig. 2.8), incorporates the fan in the collector housing. The fan blades direct the dust toward a duct leading to the receiving hopper.

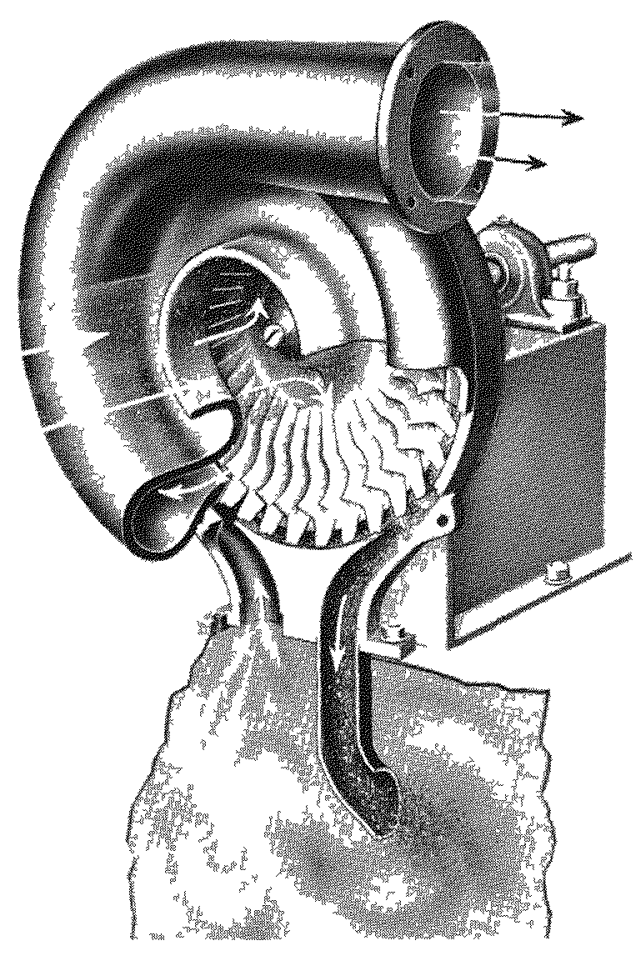

Fig. 2.7-Sirocco Type D Cyclone (American Blower Co.)

The pressure drop through a cyclone is usually less than 4 inches of water. A better indication of power and static pressure requirements, however, is the total energy loss which takes into account the energy change due to differences in area between entrance and exit ducts. First ${ }^{28}$ suggests the following expression for energy loss with clean air: 


$$
\begin{aligned}
\mathrm{F}_{\mathrm{n}}=\mathrm{F} / \mathrm{n}= & \mathrm{F} / 0.003 \rho \mathrm{V}_{\mathrm{i}}{ }^{2}=\left(12 \mathrm{bh} / \mathrm{ke}_{\mathrm{x}}{ }^{2}\right) / \\
& \left(\mathrm{L}_{\mathrm{c}} / \mathrm{D}_{\mathrm{c}}\right)^{1 / 3}\left(\mathrm{H}_{\mathrm{c}} / \mathrm{D}_{\mathrm{c}}\right) \\
\text { where } \mathrm{F}_{\mathrm{n}}= & \text { total energy loss in number } \\
& \text { or inlet velocity heads } \\
\mathrm{F}= & \text { total energy loss-inches of } \\
& \text { water } \\
\mathrm{n}= & \text { inlet velocity head-inches of } \\
& \text { water } \\
\mathrm{V}_{\mathrm{i}}= & \text { inlet gas velocity-ft. } / \mathrm{sec} . \\
\rho= & \text { inlet gas density-1bs./CF } \\
\mathrm{b}= & \text { entry width-feet } \\
\mathrm{h}= & \text { entry height-feet } \\
\mathrm{e}_{\mathrm{x}}= & \text { exit duct diameter }- \text { feet } \\
\mathrm{L}_{\mathrm{c}}= & \text { cyclone cylinder height }-\mathrm{feet} \\
\mathrm{D}_{\mathrm{c}}= & \text { cyclone cylinder diameter }- \\
& \text { feet } \\
\mathrm{k}= & \text { entry vane factor } \\
= & 1 / 2 \text { with no entry vane } \\
= & 1 \text { with entry vane which splits } \\
& \text { the annular section } \\
= & 2 \text { with entry vane which ex- } \\
& \text { tends to exit duct wall }
\end{aligned}
$$

Illustrative example, 2.2:

Consider a cyclone, handling $6000 \mathrm{CFM}$, which has the following dimensions: $\mathrm{D}_{\mathrm{c}}=4^{\prime}, \mathrm{b}=1^{\prime}, \mathrm{h}=2^{\prime}, \mathrm{L}_{\mathrm{c}}=8^{\prime}, \mathrm{H}_{\mathrm{c}}=8^{\prime}$, $e_{x}=2^{\prime}$; there is no entry vane. It is desired to design a group of new cyclones, each with the same proportions and inlet velocity as the original but with diameters of 6 inches. (a) How many of these new cyclones will be necessary to handle the original flow rate? (b) What was the original energy loss in inlet velocity heads and in inches of water? (c) What is the energy loss of the new cyclones in inlet velocity heads and in inches of water?

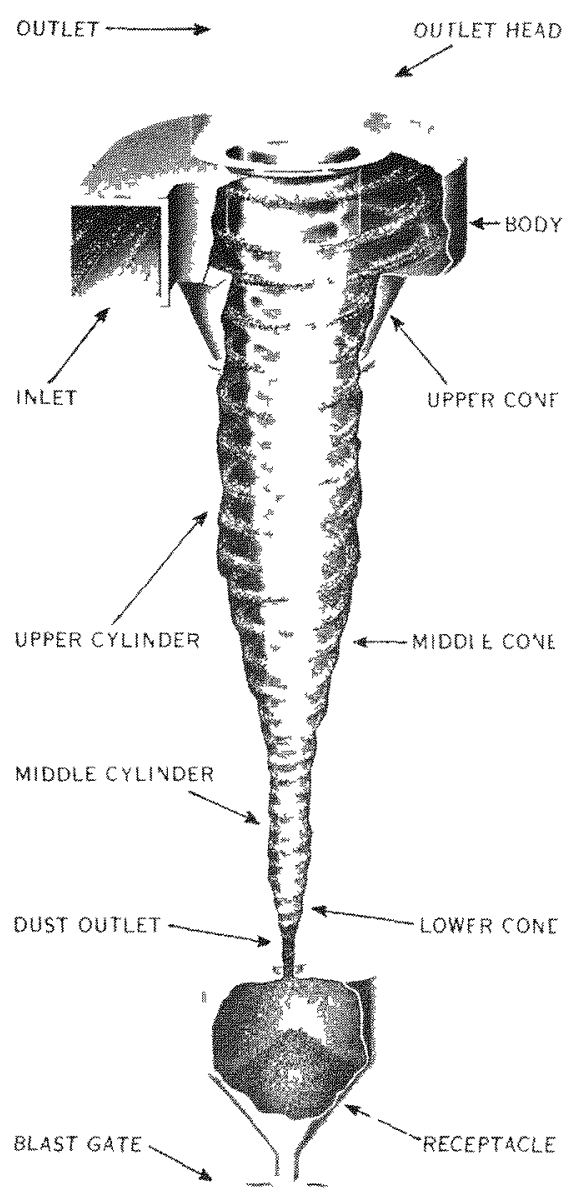

Fig. 2.8-Rotoclone Type D (American Air Filter Co.)

a) $V_{1_{1}}=V_{i_{2}}=\frac{Q}{b h}=6000 / 2(1)=3000 \mathrm{FPM}$ $\mathrm{h}_{1}=\mathrm{D}_{\mathrm{c}_{1}} / 2$

$\therefore \mathrm{h}_{2}=\mathrm{D}_{\mathrm{c}_{2}} / 2=0.5 / 2=0.25^{\prime}$

$\mathrm{b}_{1}=\mathrm{D}_{\mathrm{c}_{1}} / 4$

. $b_{2}=D_{c_{2}} / 4=0.5 / 4=0.125^{\prime}$

$\mathrm{Q}_{2}=\mathrm{b}_{2} \mathrm{~h}_{2} \mathrm{~V}_{\mathrm{i}}=3000(0.25)(0.125)=94$

CFM and number of new cyclones $=6000 / 94=64$ 
b) From Eq. 2.2:

$$
\begin{aligned}
F_{1} & =(12(1)(2) /(1 / 2)(4)) /(8 / 4)^{1 / 3}(8 / 4)^{1 / 3} \\
& =12 /(2)^{2 / 3}=7.6 \text { inlet velocity heads } \\
& =7.6(0.003)(.075)(3000 / 60)^{2} \\
& =4.28 \text { inches of water }
\end{aligned}
$$

c) From Eq. 2.2, the energy loss in inlet velocity heads and inches of water for the new cyclones is the same as for the old.

\section{Baffle Chambers}

Another way to apply a centrifugal force to dispersed particles is to obstruct the path of the fast moving gas stream with baffles. As in the cyclone, the sudden change in direction of the gas stream upon reaching the baffle causes deposition of the heavier particles. The pressure drop across a baffle chamber is generally low, but its efficiency in removing particles smaller than 10 or 20 microns is also low. This type of collector is much used as a precleaner before bag filters.

\section{Impingement Collectors}

The Calder-Fox scrubber is an impingement device used principally for the removal of sulfuric acid mists. It consists of a series of perforated plates with staggered openings. As the gas passes through the perforations, its change in direction causes deposition of the droplets. Acid removal efficiencies as high as $97 \%(1, \mathrm{p}$. 139) have been obtained with this collector, but it is effective only for particles larger than about 2 microns in diameter.

\section{SCRUBBERS AND OTHER WET COLLECTORS}

Scrubbers, washers, and their various modifications are widely used in industry for cleaning and cooling air and other gases. Water is naturally the liquid most used and to it may be added caustic (for acid mist collection) or wetting agents. Live steam and simple water sprays are sometimes applied, while oils may be used for removing substances not readily wetted by water. Capacities are relatively large and cleaning efficiencies, at both high and low dust loadings, may be sufficient for primary cleaning. For AEC purposes, wet collection has the advantage of continuous removal of radioactive waste, permitting control of the level of contamination in the collector. Moreover, in many cases it is easier to handle and dispose of liquid wastes than of solid.

It is not possible to obtain a high cleaning efficiency for sub-micron particles in any of the wet devices without a high energy expenditure. This is made obvious when one attempts to catch mists or fumes as of sulfuric acid or ammonium chloride. The particulate matter is soluble, even hygroscopic, yet one can bubble air suspensions of each through a long series of gas washing bottles with little removala classic lecture demonstration. When bubble size is reduced to the microscopic, as by fritted glass or alundum plates, collecting efficiencies are high but so is power consumption. The addition of wetting agents to scrubbing water decreases bubble size, accentuates frothing, increases entrainment, and usually adds very little to collecting efficiencies.

An important practical difficulty in these wet collectors which is likely to apply to various $A E C$ problems is corrosion. For example,gases from power plants burning soft coal contain varying amounts of $\mathrm{SO}_{2}$ and a high percentage of $\mathrm{CO}_{2}$. The $\mathrm{CO}_{2}$ 
can generally be ignored but the $\mathrm{SO}_{2}$ sometimes reaches concentrations comparable to those from plants smelting sulfide ores. Such gases can be cleaned successfully by scrubbers but corrosion is serious.

However, the heavy chemical industry has collected gases like $\mathrm{HCl}$ for years with units which resist corrosion. Efficiencies are not impressive: the plants are apt to be messy and depreciation is high-criticisms bordering on the esthetic but ones which cannot be ignored when handling materials such as the AEC does routinely.

Some of the washers and scrubbers which have been used or considered for use by the AEC are described below. Other wet collectors are discussed by Roberts, ${ }^{29}$ Lapple, ${ }^{5}$ and Brandt. ${ }^{30}$

\section{Air Washers}

Commercial air washers, so useful for dew point control in air conditioning, are only fair air cleaners, and their effectiveness is not increased significantly by excessive use of either hot or cold water. In the most common type, the air flows horizontally through a chamber containing banks of nozzles set at different heights above the level of the sump water (Fig. 2.9). The water may be sprayed with or against the air stream, or in both directions by different sets of nozzles. Eliminators, usually zig-zag plates, are placed at the exit to remove mist particles, and, in some cases, wetted baffle plates are installed across the air stream in the chamber itself. Water requirements for air washers range from about 0.5 to 20 gallons $/ 1000$ CF of gas.

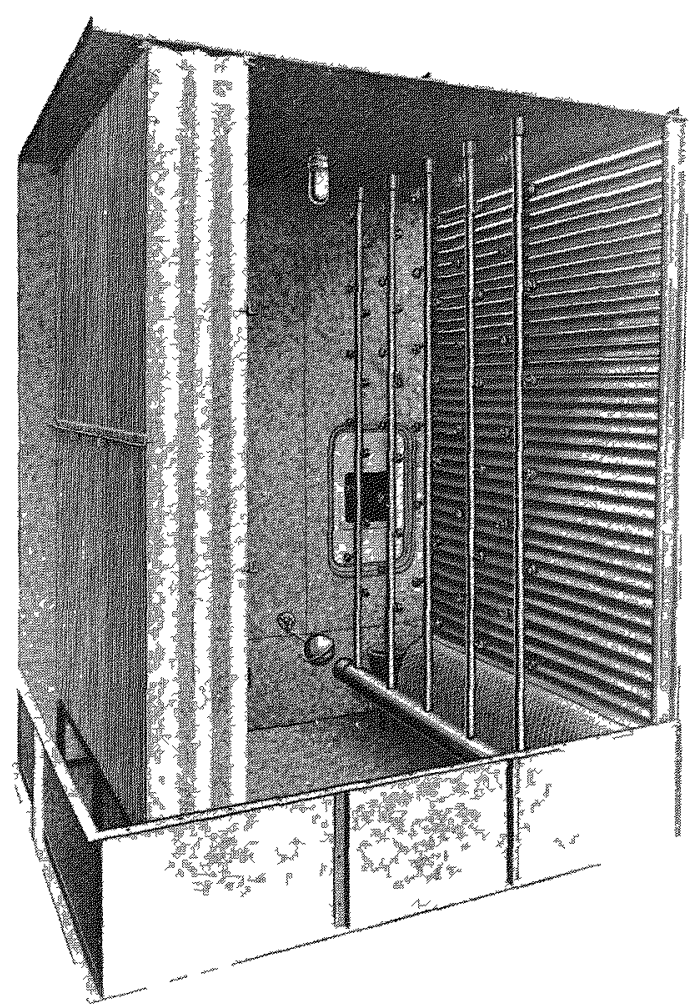

Fig. 2.9-Air Washer - Note the zig-zag eliminator plates at the left. (Clarage Fan Co.)

\section{Wet Filters}

The wet filter has the same general applications as the air washer. It consists of banks of cells containing glass filaments (about 0.01 inches in diameter) often oriented in the direction of the air stream (Fig. 2.10). The cells are 20 inches square and 3 to 8 inches thick, and are set at an angle to the gas flow. Nozzles installed above them spray water with or against the stream (Fig. 2.11); the water collects at the bottom and may be recirculated through the nozzles. Entrained liquid droplets are removed at the exit either by 


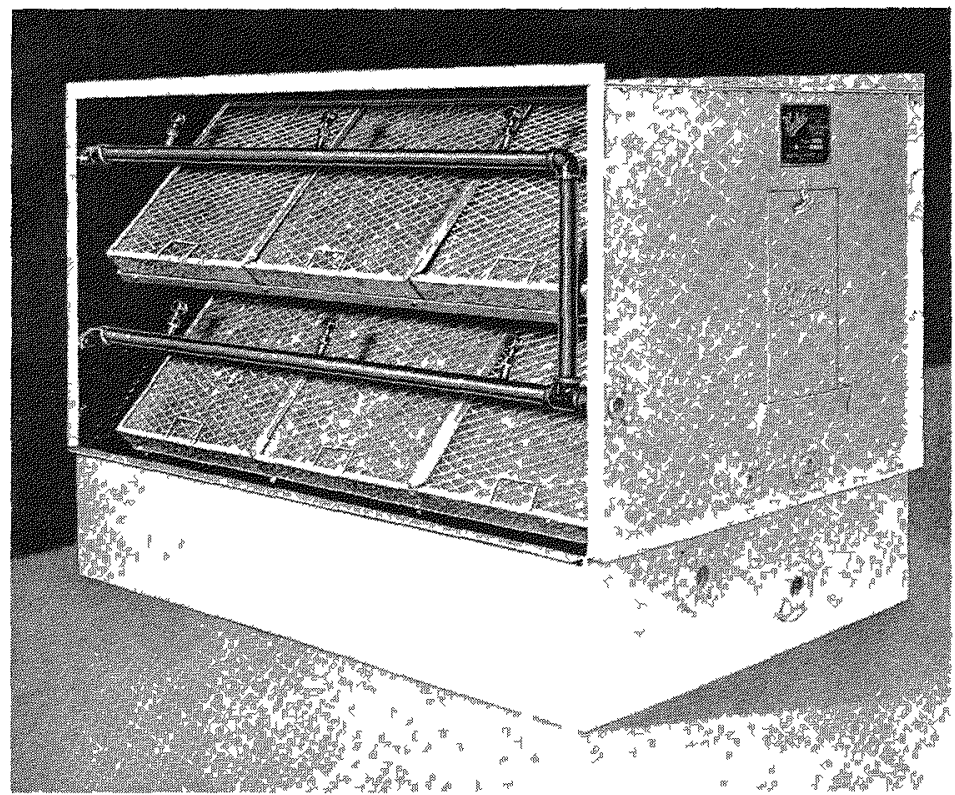

Fig. 2.10-Wet Filter (Buffalo Forge Co.)

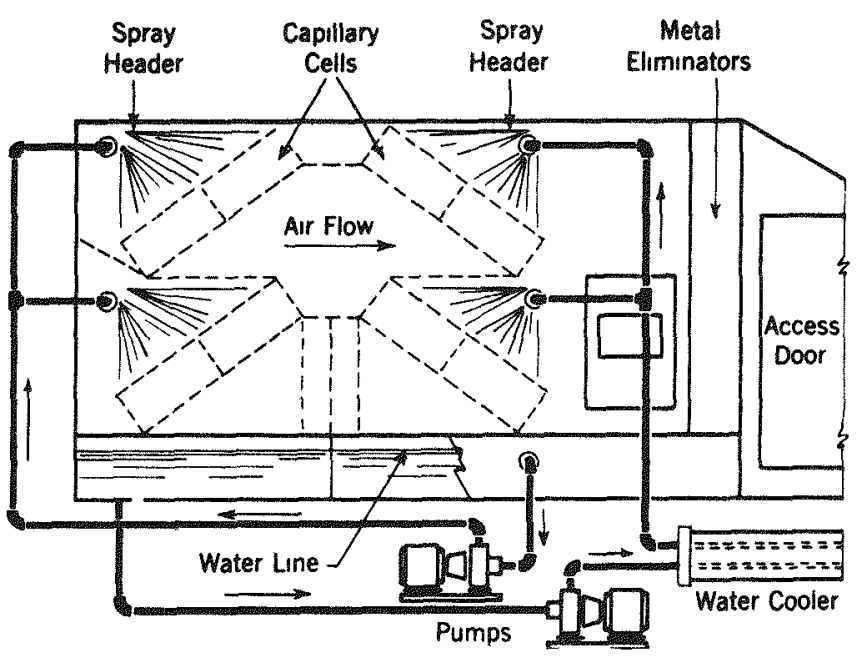

Fig. 2.11-Wet Filter - The two cells and spray nozzles on the left are arranged concurrent, and the others countercurrent, to the air flow. (Alr and Refrigeration Corp.)

zig-zag plates or glass fiber pads. Water requirements for the wet filter are about 3 gallons $1000 \mathrm{CF}$. Most of the cleaning in both the air washer and wet filter is accomplished by the zig-zag plates or the fiber glass pads at the exit. 
Our Laboratory has tested wet filters with a variety of aerosols at concentrations ranging from $10^{-5}$ to 1 grain $C F$ $\left(0.023\right.$ to $\left.2300 \mathrm{mg} \mathrm{m}^{3}\right) .{ }^{31}$ The results indicate that the coarse fiber pads commonly

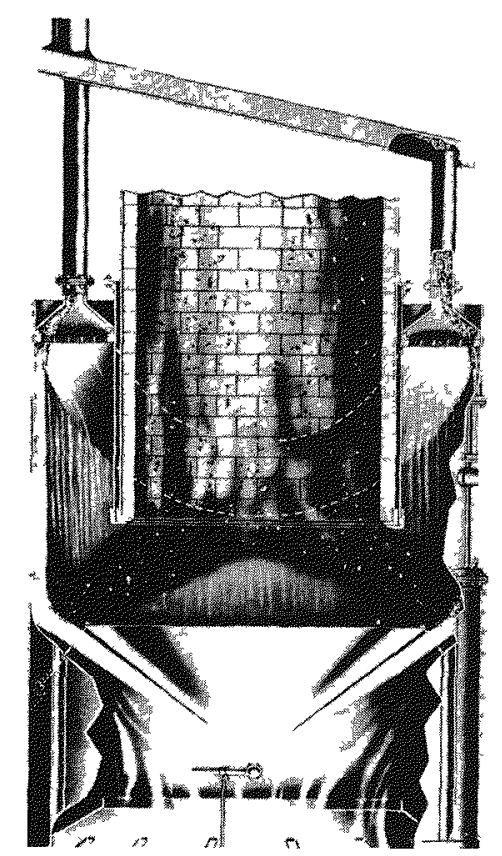

Fig. 2.12-Stack Gas Spray Washer - Dirty aur leaving the stack passes around the cone upon which the spray is directed. (Whiting Corp.)

used in such cleaners are ineffective for submicron particles of insoluble substances. Removal was about the same for both wet and dry operation. However, high efficiencies were obtained during wet operation with acid mists and vapors. Decreasing fiber size increased efficiency, but the use of fine glass wool (less than 10 microns) in washers is limited since the pads mat and sag from their supports when wetted.

\section{Spray Towers}

This type often is plant-made by fitting a tower, or even a flue, with water sprays at the top or along the walls (Fig. 2.12). Baffle plates which are continually wetted by the spray generally are installed along the sides. Dusty gas is passed either up

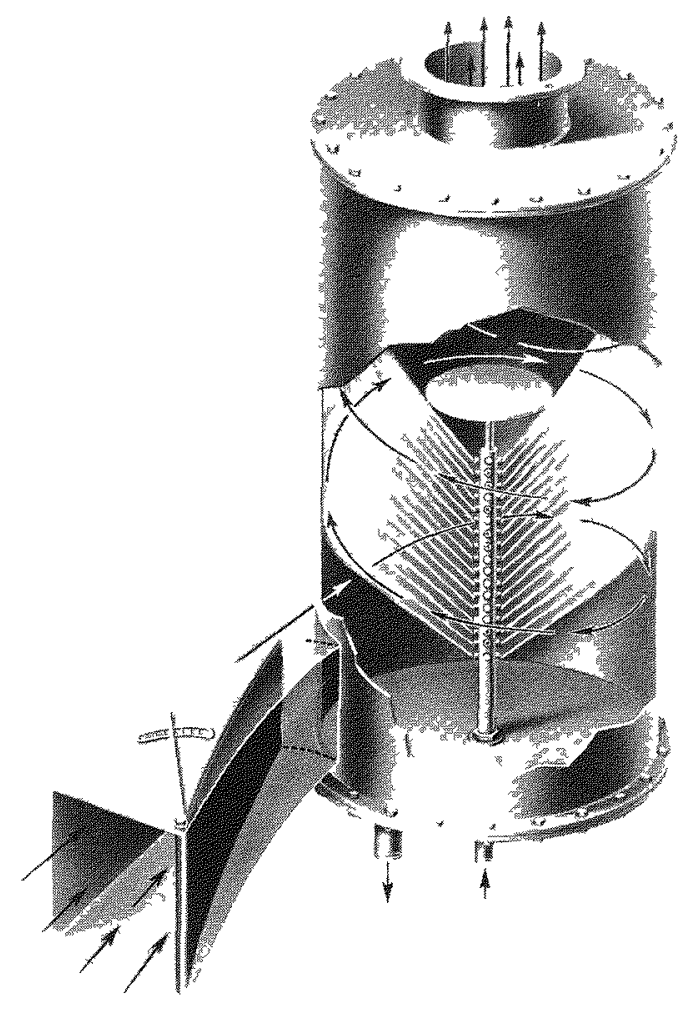

Fig. 2.13-Cyclone Scrubber (Chemical Construction Corp.)

or down the tower. Since much of the removal is due to centrifugal effects at the baffles, the gas velocity must be fairly high. Spray towers are employed as coolers and as primary cleaners in treating blast furnace gas and for flyash and cinder removal. 


\section{Centrifugal or Inertial Scrubbers}

In this type, directional changes of the gas are used to (1) hurl the water droplets through the gas, (2) separate the droplets with their attached dust load, and (3) remove dry particles by impacting them on wetted surfaces. There are many varieties, including those of plant construction, and only a few of the standard devices are described here (Figs. 2.12 through 2.18).

The Pease-Anthony cyclone scrubber consists of a vertical cylinder with spray nozzles installed at the center (Figs. 2.13 and 2.14). The gas enters the cylinder through a tangential duct at the bottom; as it spirals upward, it is sprayed with a radial rain of water droplets. Many of the particles are caught at the wetted walls. The cleaned gas passes out at the top and the dirty water is drained from the bottom. This scrubber is used as a primary cleaner for the cleaning of blast furnace gas and power plant effluent. Water rates generally range between 5 and 10 gallons/ $1000 \mathrm{CF}$.

In the Type W Rotoclone (Fig. 2.15), the water is sprayed on the dusty air at the inlet and on the moving fan blades incorporated in the collector housing. While some particles are swept out by the droplets most separation occurs by impaction on the wetted fan blades. This collector is much used for dust control in foundries.

Instead of spraying the water into the gas, the aerosol may be passed over the surface of a liquid bath as in the Type $\mathrm{N}$ Rotoclone (Fig. 2.16). Some of the particles are removed by the change in direction of the gas at the surface; others are wetted by entrained water droplets and separated by gravity or by striking baffle plates above the bath. The particles settle to the bottom of the liquid and are removed either continuously or periodically. Such wet collectors are used for removing magnesium or aluminum dusts

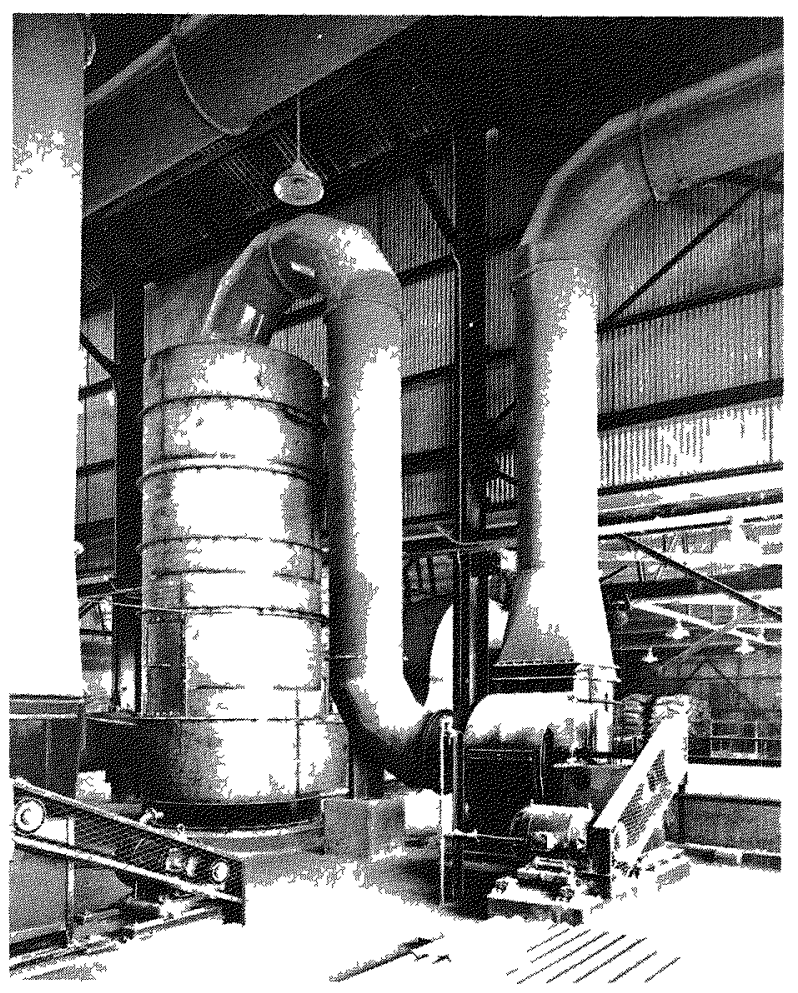

Fig. 2.14-A Cyclone Scrubber Installation (Chemical Construction Corp.)

from grinding, buffing, and polishing operations.

\section{Venturi Scrubber ${ }^{32}$}

In this device, the gas enters a cylindrical cyclone separator through a duct in the shape of a Venturi tube (Figs. 2.19 and $2.20)$. Water is introduced at the throat where it is atomized by the high velocity (over 12,000 FPM) gas stream. Droplets and the particles which they carry are 


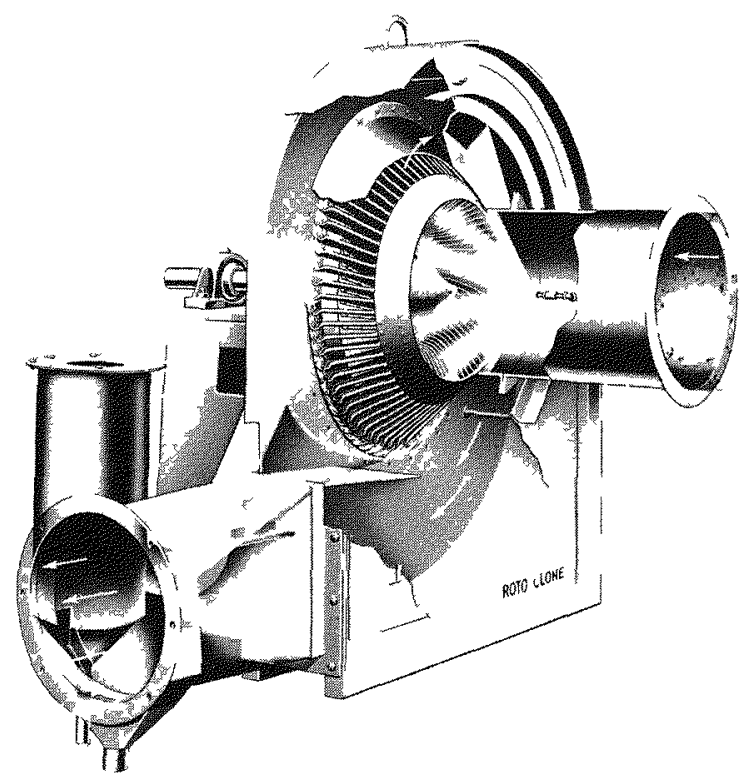

Fig. 2.15-Rotoclone Type W (American Air Filter Co.)

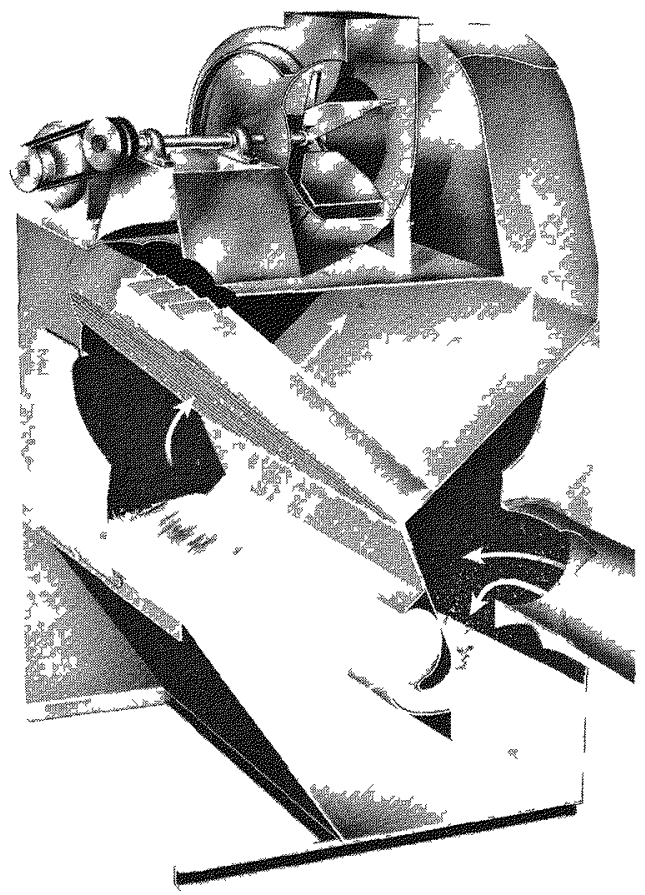

Fig. 2.16-Rotoclone Type $N$ (Amencan Air Filter Co) removed in the cyclone. This form of scrubber is used for the recovery of sodium compounds from the stack gases of paper mills and for the removal of lead oxide fume from reverbatory furnaces. It is particularly suitable for sulfuric acid mist collection. Advantages are a high cleaning efficiency, simplicity, and flexible capacity. Dirty water can be recirculated with little danger of plugging since it is introduced either through a collar or through wide pipes. However, the device has a very high pressure drop (over 10 or 15 inches). Power requirements range from about 3 to $5 \mathrm{HP} / 1000 \mathrm{CFM}$ and water rates from 2 to 9 gallons $/ 1000 \mathrm{CF}$.

\section{FILTERS}

This is probably the most important class of air cleaners for the AEC's problems. We can divide them into at least three groups:

a) Air conditioning units handling large air volumes with low dust loads. Atmospheric dust removal efficiency is generally less than $50 \%$ by weight, and filters of this type are known to the trade as roughing filters. These are often used as precleaners by AEC sites, but higher efficiency types of fibrous filters (such as resin-bonded AA glass fibers) are usually more suitable.

b) Cloth filters used for heavy dust loadings. They collect dust in bulk and discharge air clean enough to meet most hygienic specifications.

c) High efficiency filters made of various materials including cellulose-asbestos paper, compressed glass fibers, composite 


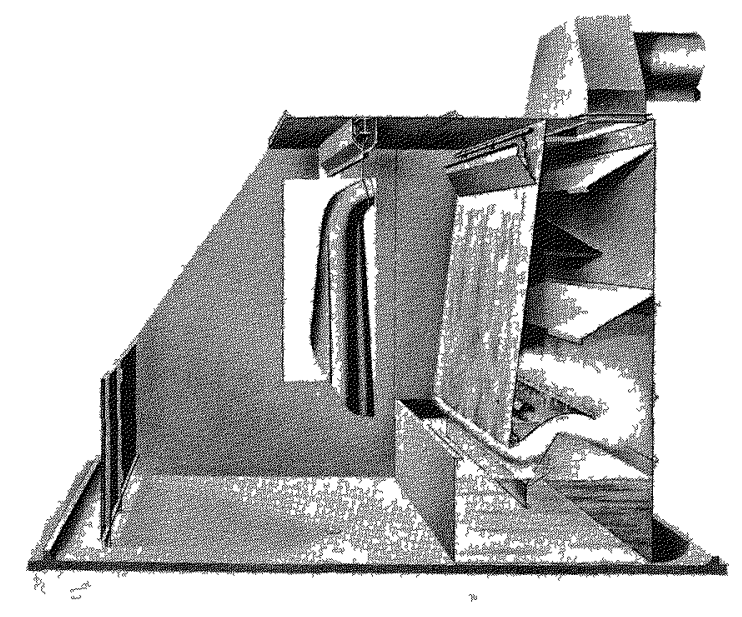

Fig. 2.17-Centrimerge (Schmieg Industries, Inc.)

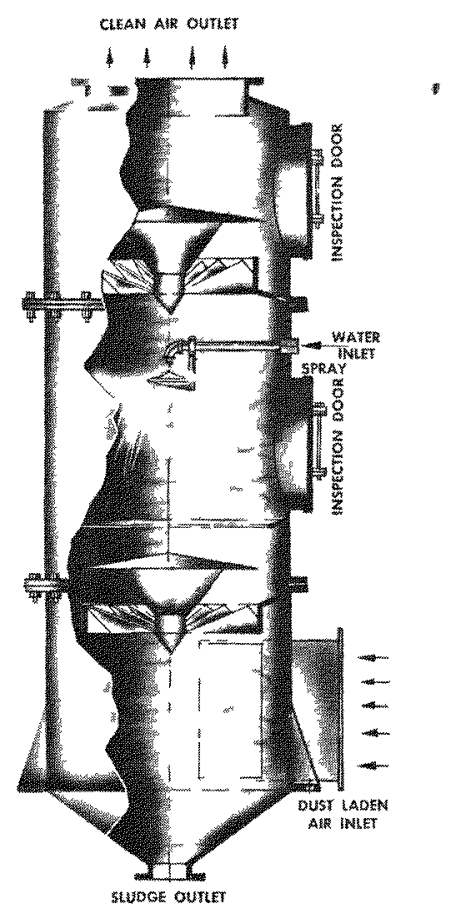

Fig. 2.18-Centrifugal-Wash Collector (Ducon Co.) beds of glass wool pads, wool containing deposited resin, or deep beds of sand. They are used for the final clean-up of poisonous and radio-active dusts.

\section{Air Conditioning Filters}

These are classed as viscous or dry. . In the viscous type (Fig. 2.21), the filter

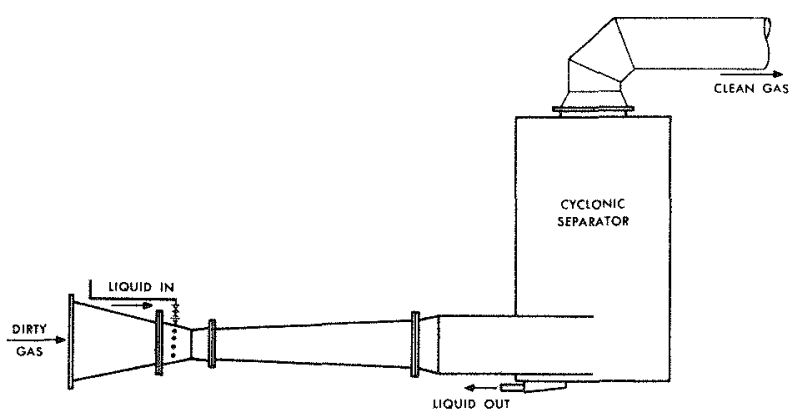

Fig. 2.19-Schematic Diagram of Venturi Scrubber (Chemical Construction Corp.)

is coated with a sticky material or " adhesive" to help catch the particles and prevent reentrainment. The adhesive is usually an oil or grease of high flash point and low volatility, and it should be a good wetting agent. The filter medium, generally glass wool, wire screen, animal hair, or hemp fibers, is placed in a metal or cardboard and wire frame approximately 20 inches square and several inches deep. The fibers may be packed with increasing density from front to back so that most of the large particles are removed before the more efficient back part is reached (Fig. 2.22); this prolongs the life of the filter. When resistance to air flow becomes excessive, glass wool media are generally 
discarded while the wire mesh is washed with hot water and then re-oiled.

Viscous filters are also made up as a belt of metal panels which moves perpendicularly to the air stream (Fig. 2.23). The panels are attached to chains mounted on sprockets at the top and bottom of the filter housing. The belt travels up one side of the sprockets, down the other, and crons for which their efficiency is usually over $85 \%$ (5, p. 1047).

Dry filters (Fig. 2.24) for air conditioning are supplied in units similar in size to the viscous type except that the depth of the dry cell is usually greater. The filter material may be from a variety of sources such as paper, glass fibers, or cotton batting. The properties of various types of

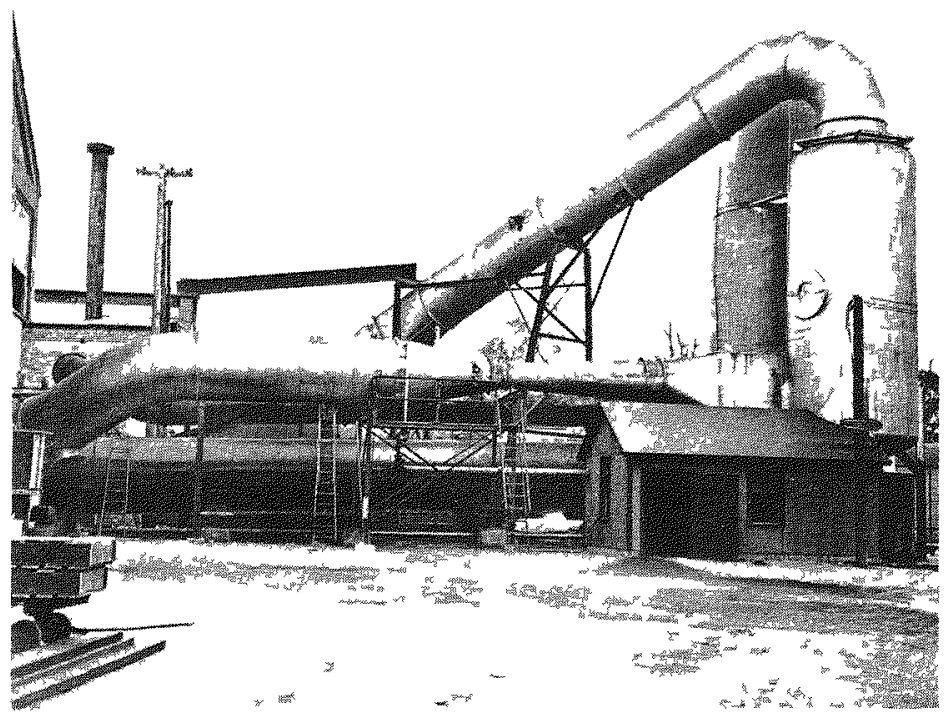

Fig. 2.20-Venturi Scrubber (Chemical Construction Corp.)

then passes through an oil bath at the bottom of the housing. Here the panels are cleaned and oiled while the dust settles out as a sludge.

Since air cleaning by viscous filters is due principally to impaction of the particles on the sticky surfaces, high air velocities (300 to 500 FPM) give the best results. Viscous filters are particularly useful for cleaning air containing oily or greasy substances. They are intended to catch particles larger than about $10 \mathrm{mi}$ -
Fiberglas (Owens-Corning Corporation) are given in Table 2.3. For the most efficient types, air passages are generally smaller than those of the viscous media; consequently, it is necessary to operate at much lower velocities (30 to $60 \mathrm{FPM}$ as contrasted with 300 to $500 \mathrm{FPM}$ for viscous filters) to avoid excessive resistances. Since the velocities are low, filter area may be increased by arranging the surface in an accordion form with pockets and pleats (Figs. 2.24 to 2.27) for increased 
capacity. A cell two feet square may thus have a filter surface of 15 to 30 square feet. Such glass wool filters are used in the manufacturing and processing of photographic film, in the cleaning of inlet cooling air for the atomic piles, and as precleaners preceding the high grade filters discussed later. They are not intended for gases hotter than about $300^{\circ} \mathrm{F}$ since the resin bonds decompose.

When the pressure drop becomes excessive, the dry-type media are discarded. Ordinarily, renewal is necessary at intervals ranging from a month to a year. Some operators change filters after the resistance has risen to two or three times its initial value. Another practical rule of thumb is to allow the resistance of the filter to increase until the air flow rate is decreased by $10 \% * 34$

Illustrative example, $2.3:^{8}$

A system is designed for a flow rate of $6000 \mathrm{CFM}$ at a total pressure drop of 1.5 inches of water of which 0.2 inches are due to the filters when clean. Assume that the fan curve is such that for a $10 \%$ decrease in flow rate, the total static pressure is 1.6 inches. What is the maximum allowable resistance for the filter?

The initial resistance of all elements other than the filter is $1.5-0.2=1.3$ inches. Since pressure drop is proportional to the square of the flow rate, at $90 \%$ of the original rate, the resistance of the other elements is $(0.9)^{2}(1.3)=1.05$ inches. Thus the maximum allowable resistance is $1.6-1.05=0.55$ inch.

\footnotetext{
* These criteria apply also to viscous filters.
}

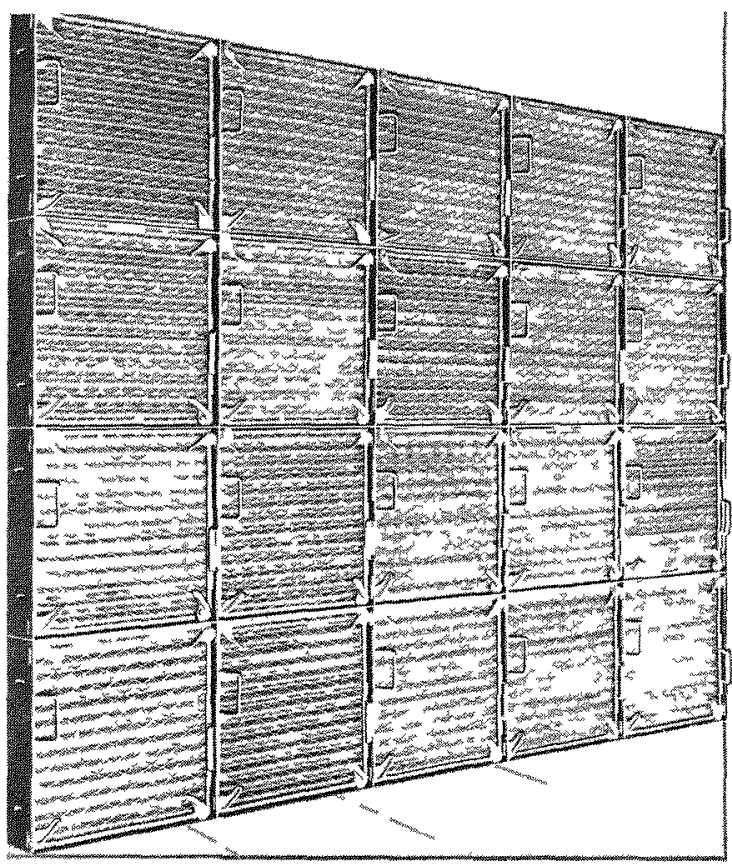

F1g. 2.21-Installation of Viscous Filters (American Air Filter Co.)

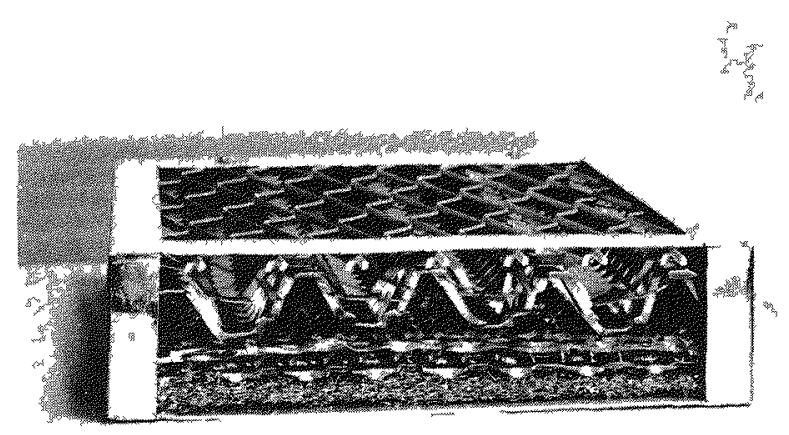

F1g. 2.22-Cross Sectional View of Viscous Filters Note the increasing density of packing of wire mesh from front to rear (American Air Filter Co.)

Blasewitz and coworkers ${ }^{33}$ have investigated the initial performance characteristics of the various types of Fiberglas, 
Table 2.3-Fiberglas Properties ${ }^{33}$

\begin{tabular}{|c|c|c|c|c|c|c|c|c|}
\hline $\begin{array}{l}\text { Fiberglas } \\
\text { type }\end{array}$ & $\begin{array}{l}\text { Fiber diameter, } \\
\text { microns }\end{array}$ & $\begin{array}{l}\text { Deviation, } \\
\text { microns }\end{array}$ & $\begin{array}{l}\text { Fiber length, } \\
\text { inches }\end{array}$ & $\begin{array}{l}\text { Type lubricant } \\
\text { or binder }\end{array}$ & $\begin{array}{l}\text { A verage packing } \\
\text { density, } 1 \mathrm{~b} / \mathrm{CF}\end{array}$ & $\begin{array}{l}\text { Packing } \\
\text { form }\end{array}$ & $\begin{array}{l}\text { Surface area } \\
\text { per lb of glass } \\
\text { sq } \mathrm{ft}\end{array}$ & Remarks \\
\hline $\mathrm{AA}$ & 1.28 & & & PFP* & 0.6 & Mat & 6038 & $\begin{array}{l}\text { Superior above } \mathrm{pH} \text { of } \\
10\end{array}$ \\
\hline B & 2.54 & & & PFP & 0.7 & Mat & 2013 & $\begin{array}{l}\text { Superior above } \mathrm{pH} \text { of } \\
10\end{array}$ \\
\hline$B(L$ and $R$ ) & 2.54 & & & PFP* & 4.0 & Mat & & $\begin{array}{l}\mathrm{L} \text { and } \mathrm{R}^{\prime \prime} \text { refers to } \\
\text { a leaching and } \\
\text { refiring process }\end{array}$ \\
\hline 55 & 14.0 & 7.5 & 6 & $\mathrm{MO}^{* *}$ & 3.0 & $\begin{array}{l}\text { Bulk and } \\
\text { mat }\end{array}$ & 537 & $\begin{array}{l}\text { Inferior in resistance } \\
\text { to high humidity } \\
\text { and acid conditions }\end{array}$ \\
\hline $55 \mathrm{P}$ & 14.0 & 7.5 & $<6$ & PFP & $1.5-6.0$ & & & $\begin{array}{l}\text { Inferior in resistance } \\
\text { to high humidity } \\
\text { and acid conditions }\end{array}$ \\
\hline 115 & 29.2 & & & PFP & & & 263 & \\
\hline $115 \mathrm{~K}$ & . & & & None & 1.5 & Bulk & 263 & $\begin{array}{l}\text { Recommended for } \\
\text { acid conditions. } \\
\mathrm{K} " \text { refers to } \\
\text { crimping of the } \\
\text { original strands }\end{array}$ \\
\hline 450 & 114 & 12.5 & 20 & PFP & 3.5 & Packs & 68.8 & \\
\hline 600 & 153 & 12.5 & 20 & PFP & 3.5 & Packs & 51.6 & \\
\hline 800 & 203 & 12.5 & 20 & PFP & 3.5 & Packs & 38.7 & \\
\hline
\end{tabular}


using cell ventilation air at Hanford as the test aerosol. The pressure drop data were correlated by equations of the form

$$
\Delta \mathrm{p}=\mathrm{KL}^{\mathrm{x}} \mathrm{v}^{\mathrm{y}} \rho_{\mathrm{p}^{\mathrm{z}}}
$$

and the efficiency data by equations of the form

$$
\log \frac{100}{16 J-n}=\frac{C L^{a} \rho_{p}^{a^{\prime}}}{v^{a^{\prime \prime}}}
$$

for each type of Fiberglas.

$$
\begin{aligned}
& w^{*} \text { e } \mathrm{L}=\text { bed depth } \\
& \rho_{\mathrm{p}}=\text { packing density } \\
& \mathrm{v}=\text { superficial velocity } \\
& \eta=\text { efficiency }
\end{aligned}
$$

$\mathrm{x}, \mathrm{y}, \mathrm{Z}, \mathrm{a}^{\prime}, \mathrm{a}^{\prime \prime}=$ experimentally determined constants (positive); values depend on the type of Fiberglas.

$$
\mathrm{K}, \mathrm{C}^{\prime}=\text { constants }
$$

This reference also gives nomograms from which the resistance and efficiency can be estimated if the characteristics of the bed are known.

From Eq. 2.3, we see that the resistance offered to the air flow by each type of Fiberglas increases with bed depth, superficial velocity, and packing density. Collection efficiency also increases with bed depth and packing density. Below 75 FPM, however, efficiency was found to be an inverse function of the superficial velocity, indicating that at low velocities diffusion plays an important part in the removal of the sub-micron particles in the process gases. The data were not correlated on the basis of fiber diameter

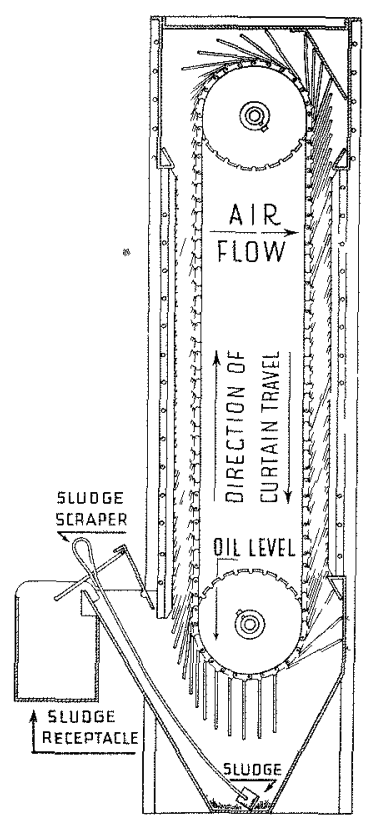

Fig. 2.23-Automatic Viscous Filter (American Air Filter Co.)

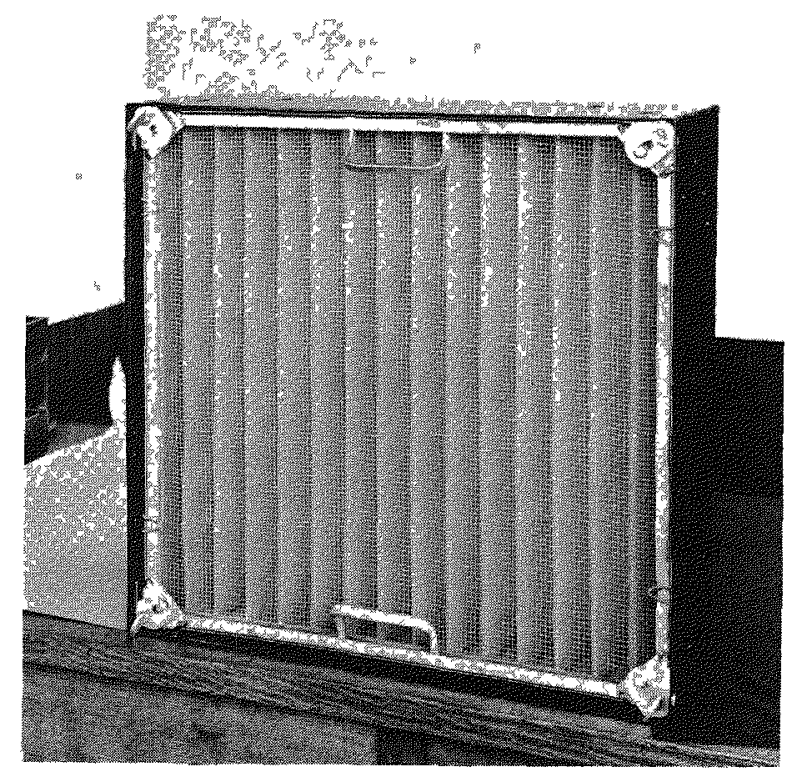

Fig. 2.24-Dry Filter (American Air Filter Co.) 


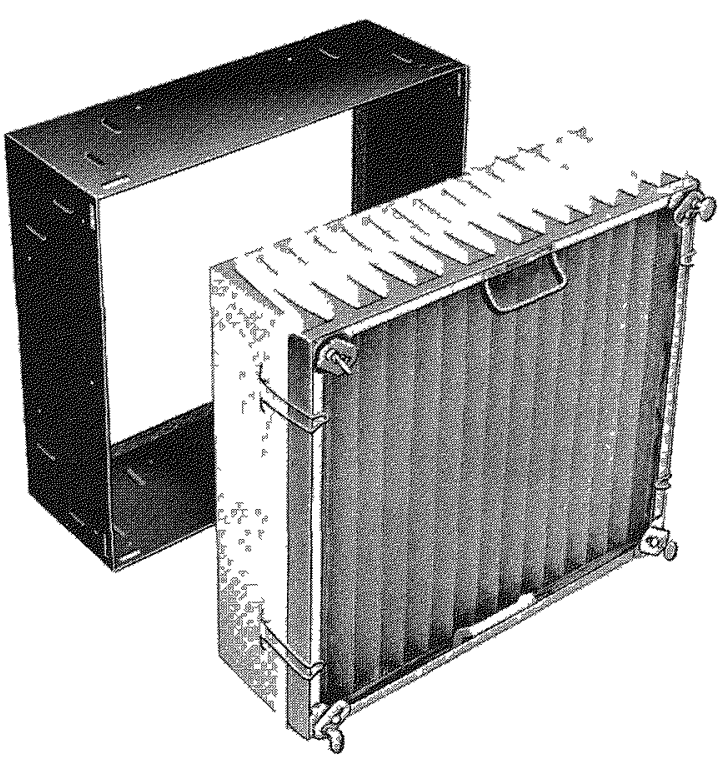

Fig. 2.25-Expanded View of Dry Filter Showing Pleated Paper Medium (American Air Filter Co.)

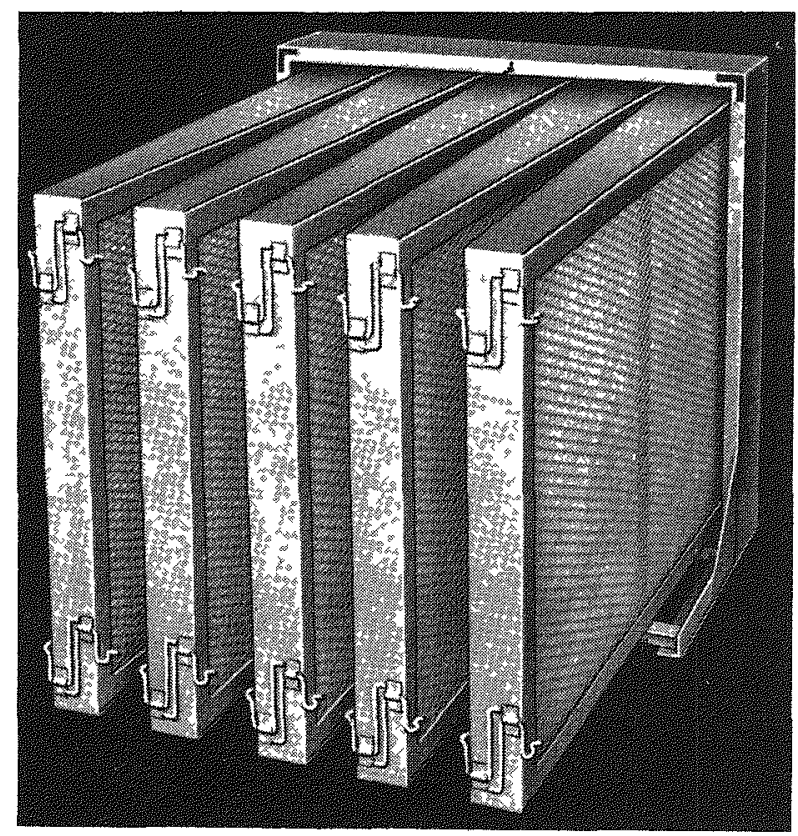

Fig. 2.27-Deep Bed Filter (Air Exit Side) - The total filtering area of the five pockets is approximately 50 square feet and the normal rating of the unit is 1000 CFM. (American Air Filter Co.)

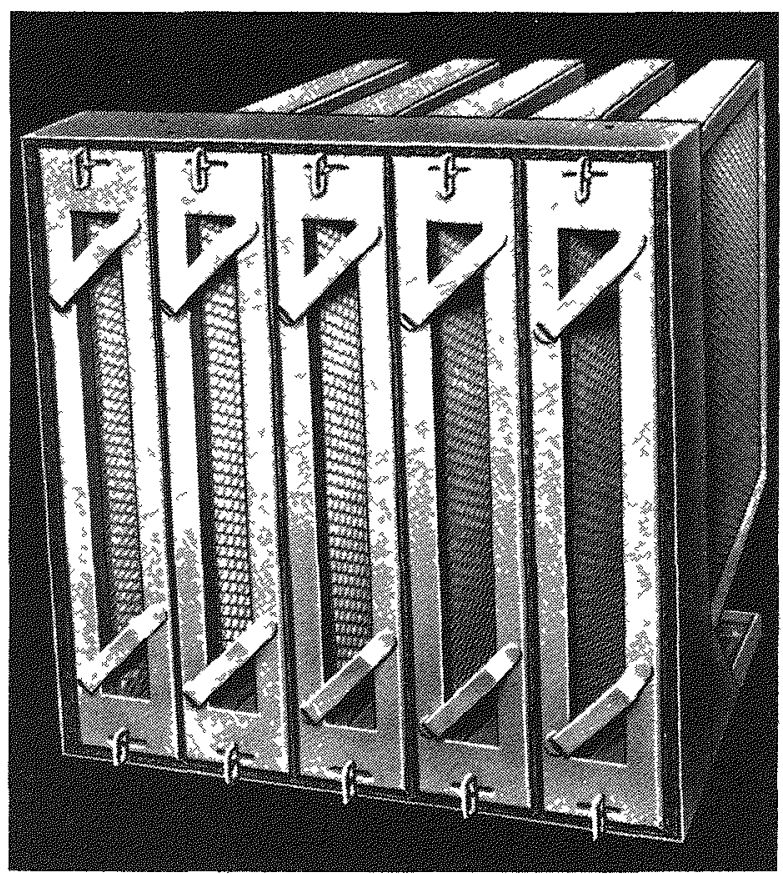

Fig. 2.26-Deep Bed Filter (Air Inlet Side) - Spring latches hold the pockets in the frame against sponge rubber seals to prevent air leakage. (American Air Filter Co.)

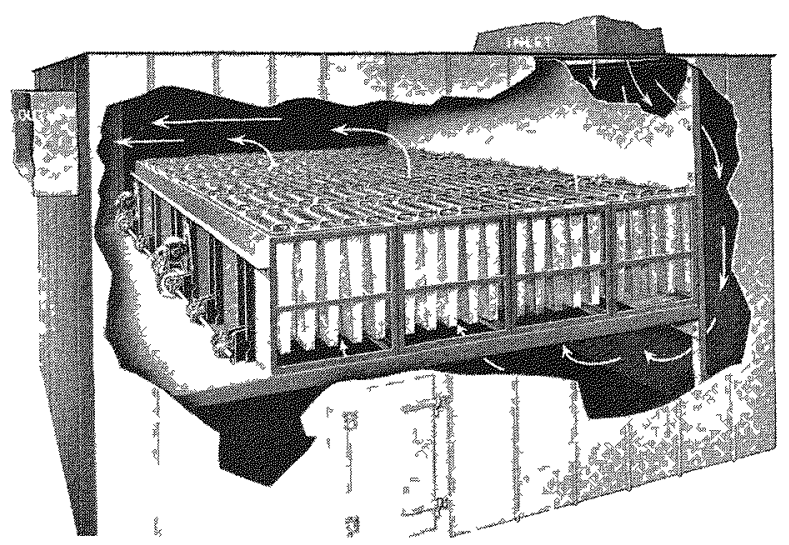

Fig. 2.28-Automatically Cleaned Dry Filter Equipped with Motor Driven Vibrators (American Air Filter Co.) 
but efficiency is generally higher for the smaller diameter filters. This group also studied the performance characteristics of Fiberglas filters as the particulate matter accumulated in the beds. They found that increasing fiber diameter or reducing packing density increased the life of the filter unit.

Dry filters which are cleaned automatically are also available. They are vibrated, rather than shaken, at intervals to dislodge the dust (Fig. 2.28). They handle higher concentrations than the usual dry cell filters but not the heavy loadings of the cloth collectors.

\section{Cloth Filters}

A common cloth filter consists of tubular bags from 5 to 18 inches in diameter and from 2 to 30 feet in length (Figs. 2.29 and 2.30). Bags for mineral dust are shorter

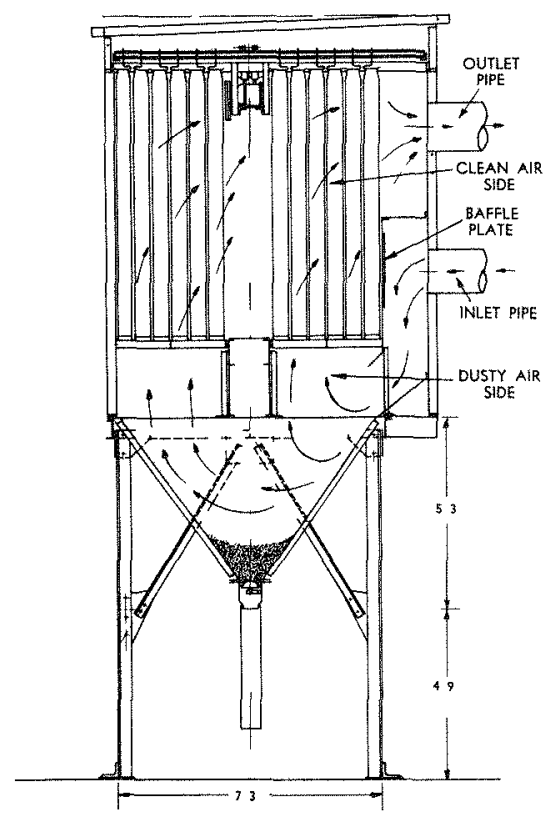

Fig. 2.29-Bag Filter (American Wheelabrator and Equipment Corp.)

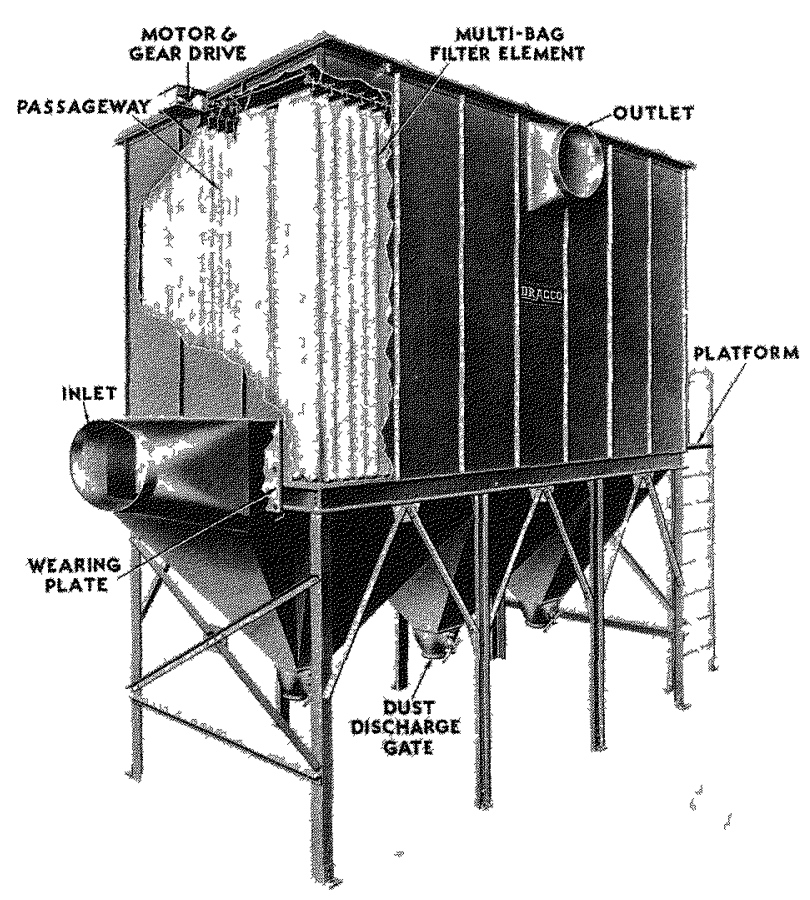

Fig. 2.30-Bag Filter (Dracco Corp.)

and narrower than those used for metallurgical fumes such as lead and zinc oxide. The tubes are suspended with open ends attached to an inlet manifold either at the bottom or top of the housing or at both; the lower manifold also serves as a receiving hopper for the dust. As the air enters, it strikes a baffle plate causing the larger particles to fall to the hopper. It then passes through the tubes, depositing its particles on the inner surfaces of the cloth. The bags are generally cleaned by shutting down at intervals and shaking at the top.

The Hersey bag filter (Fig. 2.31) is cleaned by an air jet from a traversing ring actuated by the pressure drop across the wool felt bag. It requires no shutdowns and runs at a considerably higher 
filtering velocity than the usual bag collector (up to 35 as compared with 2 or 3 FPM). The unit is expensive although in large sizes it is competitive with ordinary bag filters.

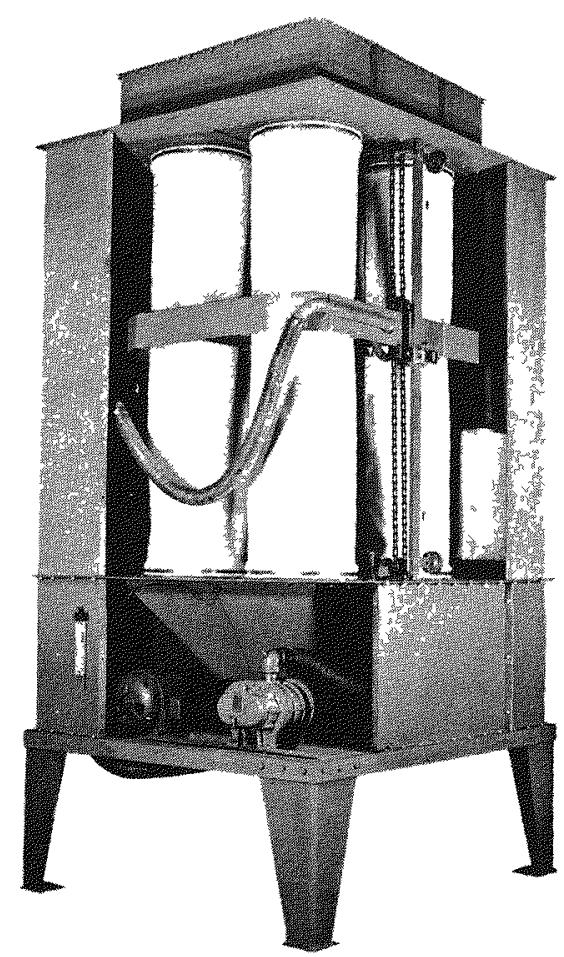

Fig. 2.31-Hersey Bag Filter (Turner-Haws Engineering Co.)

Instead of a bag, the filter may be in the form of a cloth envelope pulled over a wire screen frame like a pillow case (Figs. 2.32 and 2.33). The assembly is commonly $1 \frac{1 / 2}{2}$ to 3 feet wide, 3 to 4 feet long, and 1 or 2 inches thick. In contrast with the bag filter, air passes from the outside of each envelope into and thence out of the collector; if the flow were reversed, the envelopes would be distended and the seams subjected to strain. The units are cleaned by rapping or shaking the frames.

There is not, at present, a filter cloth that combines good filtering properties

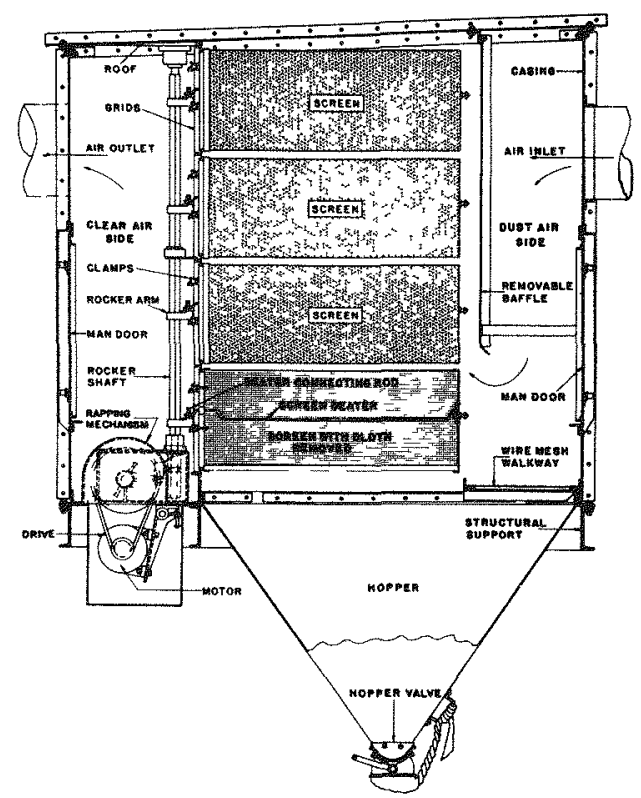

Fig. 2.32-Envelope Screen Collector (Pangborn Corp.)

with resistance to rupture, high temperatures, and corrosive gases. Cotton, the material commonly used, is satisfactory for cold, non-corrosive gases; wool felt media can handle small amounts of acid and withstand higher temperatures. Glass or asbestos cloths are sometimes employed for hot, corrosive gases, but are apt to tear during shaking. It is claimed that the new synthetic fiber, Orlon, combines most of the features of a good filter cloth, but its use is still too recent for proper evaluation. Table 2.4 gives temperature limits for various cloths.

Cloth filters depend to a great extent on the accumulated dust layer for their 
effectiveness. They work best with high loadings, and efficiencies above $99.9 \%$ are not uncommon. Attempts have been made to obtain comparable efficiencies for low

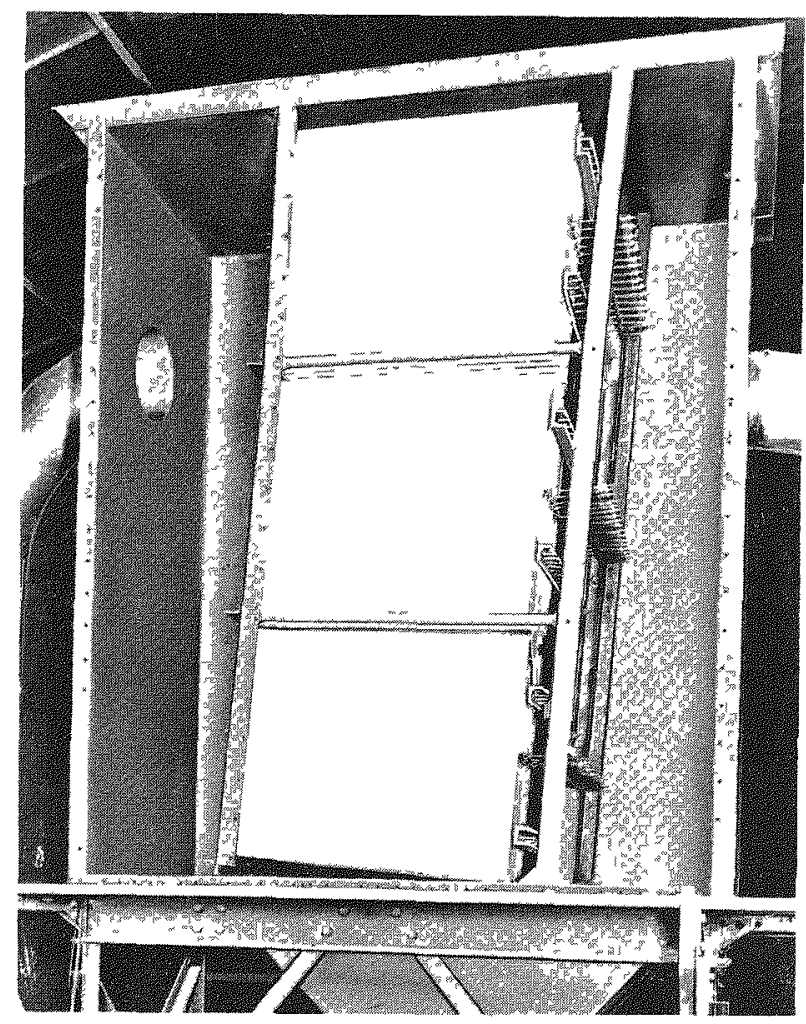

Fig. 2.33-Envelope Screen Filter (Sly Manufacturing Co.)

concentrations by coating the cloth with a flocking material before starting filtration; over $95 \%$ removal was reported for normal air in a bag filter primed with fine asbestos fibers. Cleaning was necessary only at 1 to 6 month intervals at which times a new asbestos layer was deposited on the surface of the cloth. ${ }^{35}$

The cloth filter is of great value in treating dry dusts or fumes at moderate temperatures. Iț principal limitations are the necessity for large installations because of the low filtering velocity, and an inability to handle mists or very hot or corrosive gases.

Table 2.4-Temperature Limits for Various Cloths
Material

Cotton

Wool

Orlon

Glass

Asbestos

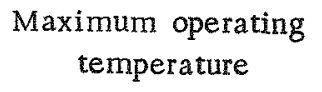

650

650

\section{High Efficiency Filters (Table 2.5)}

1. Cellulose-Asbestos Paper. At present, the AEC makes great use of $\mathrm{CC}-6$ paper which was originally developed by the Chemical Corps for use in gas masks. It consists of fine asbestos fibers mixed with coarser cellulose fibers to give mechanical strength and act as a support for the asbestos. The asbestos mesh does most of the filtering. Efficiency is initially high and increases with use. For aerosols at low concentrations, replacement may not be necessary for many months.

These filters are not intended for mists or acid vapors, and they plug very rapidly at high dust concentrations. For these reasons a dry, fibrous, glass fiber prefilter is often placed before the paper. Cellulose asbestos paper is expensive and not available in large quantities.

An improved filter has been developed by A.D. Little, Inc. ${ }^{36}$ (Figs. 2.34 and 2.35). The paper is made from materials more easily obtainable and the filter is designed for greater capacity than the $\mathrm{CC}-6$ type. 
Table 2.5-High Efficiency Filters

\begin{tabular}{|c|c|c|c|}
\hline Medium & $\begin{array}{c}\text { Test } \\
\text { aerosol }\end{array}$ & $\begin{array}{l}\text { Air } \\
\text { velocity, } \\
\text { FPM }\end{array}$ & $\begin{array}{c}\text { Resistance, } \\
\text { inches of } \\
\text { water }\end{array}$ \\
\hline
\end{tabular}

(1) Cellulose asbestos paper:

CC-6 (39)

Methylene blue

DOP

Normal air

Cell ventilation gases

(3) Composite glass wool ${ }^{\mathrm{b}}:(33)$

(4) Compressed glass fiber ${ }^{c}:(36)$

(5) Resin wool ${ }^{\mathrm{d}}: 41$
Process off-gases

Normal air

Normal air
4

5.25

5.25

$3-5$

20

5.25

14
1.0

1.0

0.8

4.5-5.5

4.0

0.69

0.3
99.9871 (discoloration)

99.9 (penetrometer)

99.98 (count)

99.5-99.8 (radioactivity)

$99.9+$ (radioactivity)

99.997 (count)

99.6 (discoloration)

a 69 " deep, graded sizes from $2 \frac{1}{2}$ " to 50 mesh.

${ }^{b}$ See Table 2.6 for composition.

c0.02" thick, $50 \% 1.3$ and $50 \% 3$ micron fibers. d $1 / 8$ " thick.

2. Deep Bed Filters. Deep bed filters are made of such materials as crushed flint, sand, or coke. They are commonly several feet thick, the exact dimensions depending on the bed material, the desired efficiency, and the permissible pressure drop.

Efficiencies as high as $99.9 \%$ (by weight) have been reported for a coke bed filtering a sulfuric acid mist composed of particles ranging from 0.5 to 3 microns. ${ }^{35}$ At Hanford results nearly as good have been obtained in cleaning cell ventilation gases with a 69 inch deep sand filter made by packing a bed with progressively finer grains of sand toward the gas exit. The sand is held in a large underground container equipped with air distributors, plenum chamber, and ductwork.

When the deep bed filter plugs, the entire unit can be abandoned and buried, thus minimizing any problems of remote main-

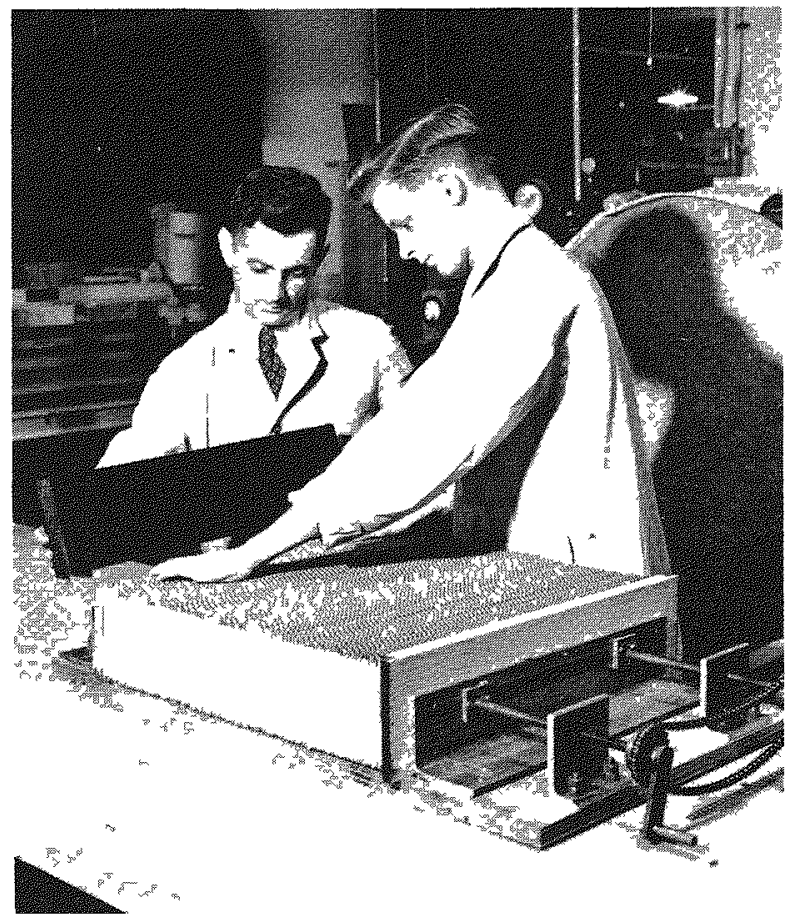

Fig. 2.34-Manufacture of Cellulose-Asbestos Paper - Note the corrugated paper spacers between the pleats of the filter medium. (A. D. Little, Inc.) 


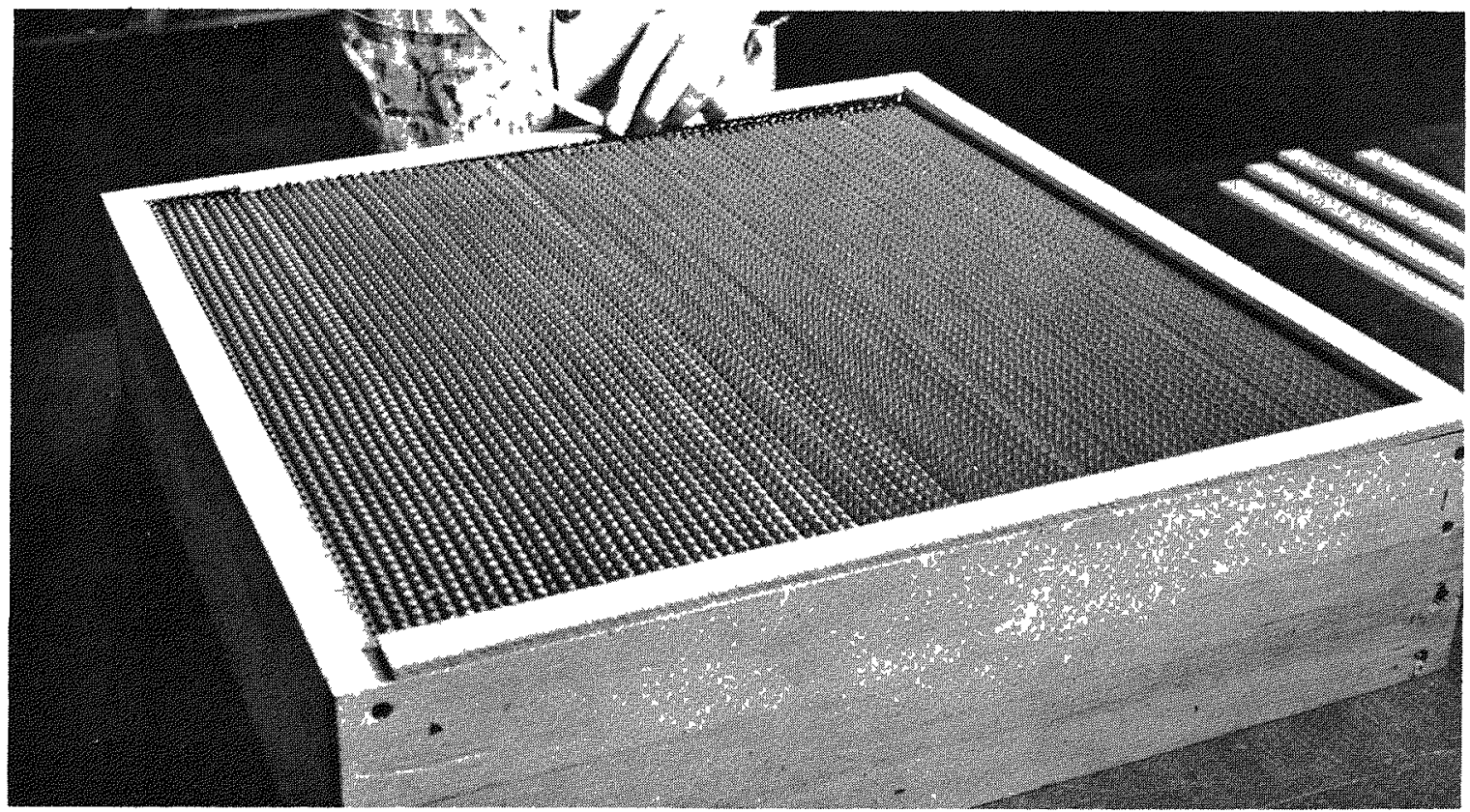

Fig. 2.35-Cellulose-Asbesto Paper Filter (A. D. Little, Inc.)

Table 2.6 - Filter Formulation for an Acid Carrying Air Stream

[Based on tests with a methylene blue aerosol ( $\mathrm{MMD}=0.6 \mu, \sigma \mathrm{g}=2.4$ ) at $20 \mathrm{FPM}$ superficial velocity]

$\begin{array}{lcccccc}\text { Layer } & \begin{array}{c}\text { Type } \\ \text { fiberglas }\end{array} & \begin{array}{c}\text { Packing } \\ \text { density, } \\ \text { lbs/CF }\end{array} & \begin{array}{c}\text { Bed } \\ \text { depth, } \\ \text { inches }\end{array} & \begin{array}{c}\text { Initial } \\ \text { efficiency, } \\ \%\end{array} & \begin{array}{c}\text { Initial } \\ \text { pressure drop, } \\ \text { inches of water }\end{array} & \begin{array}{c}\text { Life expectancy, } \\ (\Sigma) \text { grains } / \mathrm{ft}^{2}\end{array} \\ \text { Initial } & 115 \mathrm{~K} & 1.5 & 12 & 39 & 0.10 & >1400 \\ \text { Second } & 115 \mathrm{~K} & 3.0 & 10 & 53 & 0.24 & >362 \\ \text { Third } & 115 \mathrm{~K} & 6.0 & 20 & 93 & 1.34 & >228 \\ \text { Clean-up } & \text { AA } & 1.2 & 1 & 99.9 & 2.20 & >28 \\ \text { TOTAL } & & & 43 & 99.99 & 3.9 & >1400\end{array}$

* $\Sigma$ is defined as the cumulative number of grains of methylene blue passing to the filter layer per square foot of filter area to produce a resistance increase of 4 inches of water.

tenance. At Hanford, it is planned to pipe the ventilation air to a new unit leaving the original one underground when its resistance becomes excessive.
Deep bed filters suffer the disadvantage of high installation cost and require a large amount of space to insure sufficient residence time without excessive resist- 
ances. The Hanford filter, for example, is $110^{\prime} \times 48^{\prime} \times 14^{\prime}$ in size. A plant producing 30 tons of sulfuric acid per day may require a coke box 30 to 40 feet in diameter and several feet high. ${ }^{35}$

3. Composite Pads of Glass Fibers. From the studies conducted by Blasewitz et al $^{33}$ at Hanford, composite glass fiber filters were designed which combine high efficiency with predicted long life. These filters are made by placing coarse, loosely packed pads of glass fibers at the gas inlet and progressively increasing the density of packing while decreasing fiber diameter (Chap. I, p. 11). The composition of a filter designed for the process off-gases at Hanford is shown in Table 2.6. The No. $115 \mathrm{~K}$ Fiberglas was chosen because of its resistance to acid vapors which may reach a volume concentration as high as 50 to $60 \%$ in the off-gases. The actual performance figures closely approximate design predictions; during the first 6 months of operation the unit has not shown any measurable increase in pressure drop.

4. Compressed Glass Fibers. The $\mathbf{1 . 3}$ and 3 micron fibers of the $\mathrm{AA}$ and $\mathrm{B}$ pads may be compressed into sheets less than 0.01 inch thick with densities of about 20 pounds per cubic foot. ${ }^{36}$ Such compressed fiber media are very efficient filters and will withstand high temperatures. However, they are not in commercial production.

5. Resin Wool Filters. The Hansen resin filter, developed in 1930 , is made by carding various natural or synthetic resins into wool..$^{37,38}$ The small bits of resin clinging to the wool fibers carry high surface charges which cause deposition of the particles. In filtering dusts or smokes, these charges last for long periods, and if dissipated, can be restored by recarding the wool. However, mists (particularly those composed of oil droplets) cause rapid break-down of the filter by spreading over the surfaces of the resin particles. The resin filter has been used in gas masks and, on a limited scale, in bag collectors; as yet, it has found little use in cleaning atmospheric air or process gases, but the outlook for its wider use is promising.

\section{ELECTRIC PRECIPITATORS}

Cottrell precipitators are used in the metallurgical and heavy chemical industries to collect metallic oxide fumes and acid mists, and by the utilities for removing flyash. They handle gases which are hot $^{*}$ or cold, wet or dry. They work better on small particles (less than 0.5 micron) and for this reason precleaners such as cyclones and settling chambers are used to remove the larger particles and reduce the dust loading. Cottrells can usually be designed to overcome corrosion troubles.

In the air conditioning field, two-stage precipitators have come into use in the last decade. They differ from the Cottrell in that the aerosol is subjected first to an ionizing field and then to a separate collecting field. The two-stage precipitators have found considerable application in cleaning greasy suspensions, such as oil and tobacco smoke, and in removing miscellaneous dusts and smokes from foundries. They are not intended to handle heavy dust loadings.

Both types of precipitator run on rectified $\mathrm{AC}$, the Cottrells at voltages of

* Up to $1100^{\circ} \mathrm{F}$, although temperatures usually range around $600^{\circ} \mathrm{F}$ and lower. 


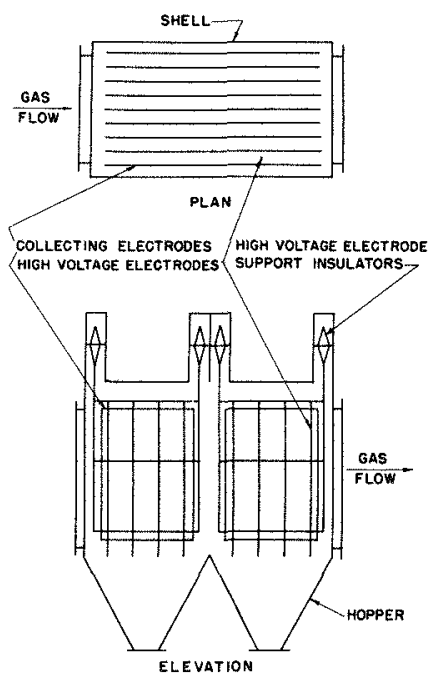

Fig. 2.36-Schematic Diagram of Plate Type Precipitator (Western Precipitation Corp.)

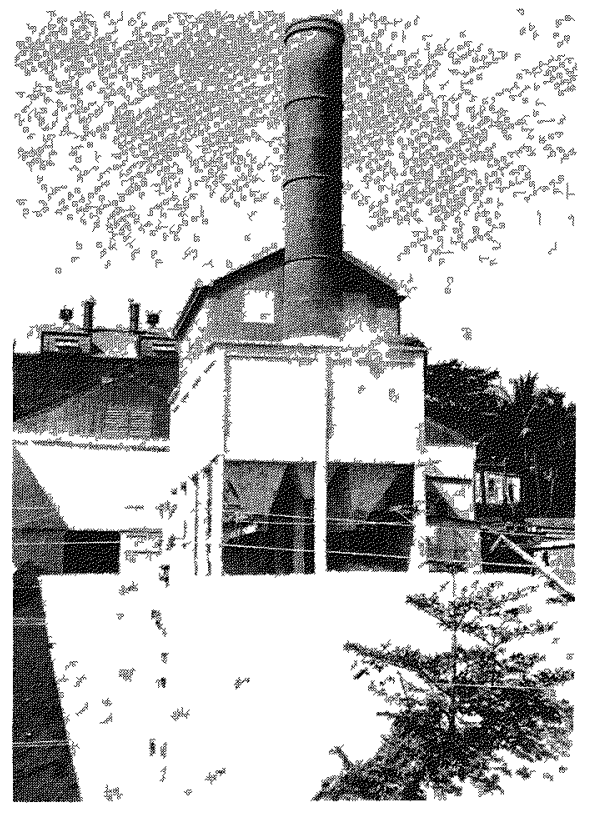

Fig. 2.38-Plate Type Precipitator Collecting phosphate on Ocean Island (Western Precipitation Corp.)

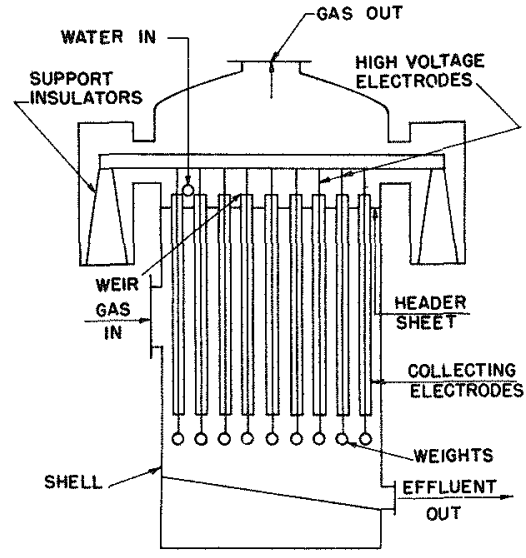

Fig. 2.37-Schematic Diagram of Pupe Type Precipitator (Western Precipitation Corp.)

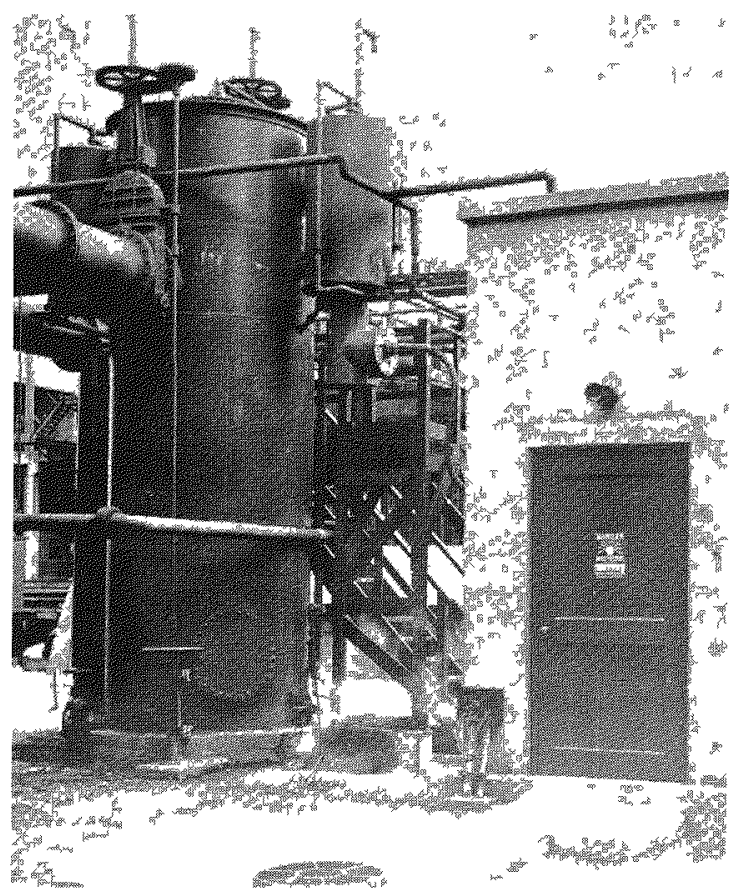

Fig. 2.39-Pipe Type Precipitator Cleaning Coke Oven Gases at a Steel Plant (Westem Precipitation Corp.) 


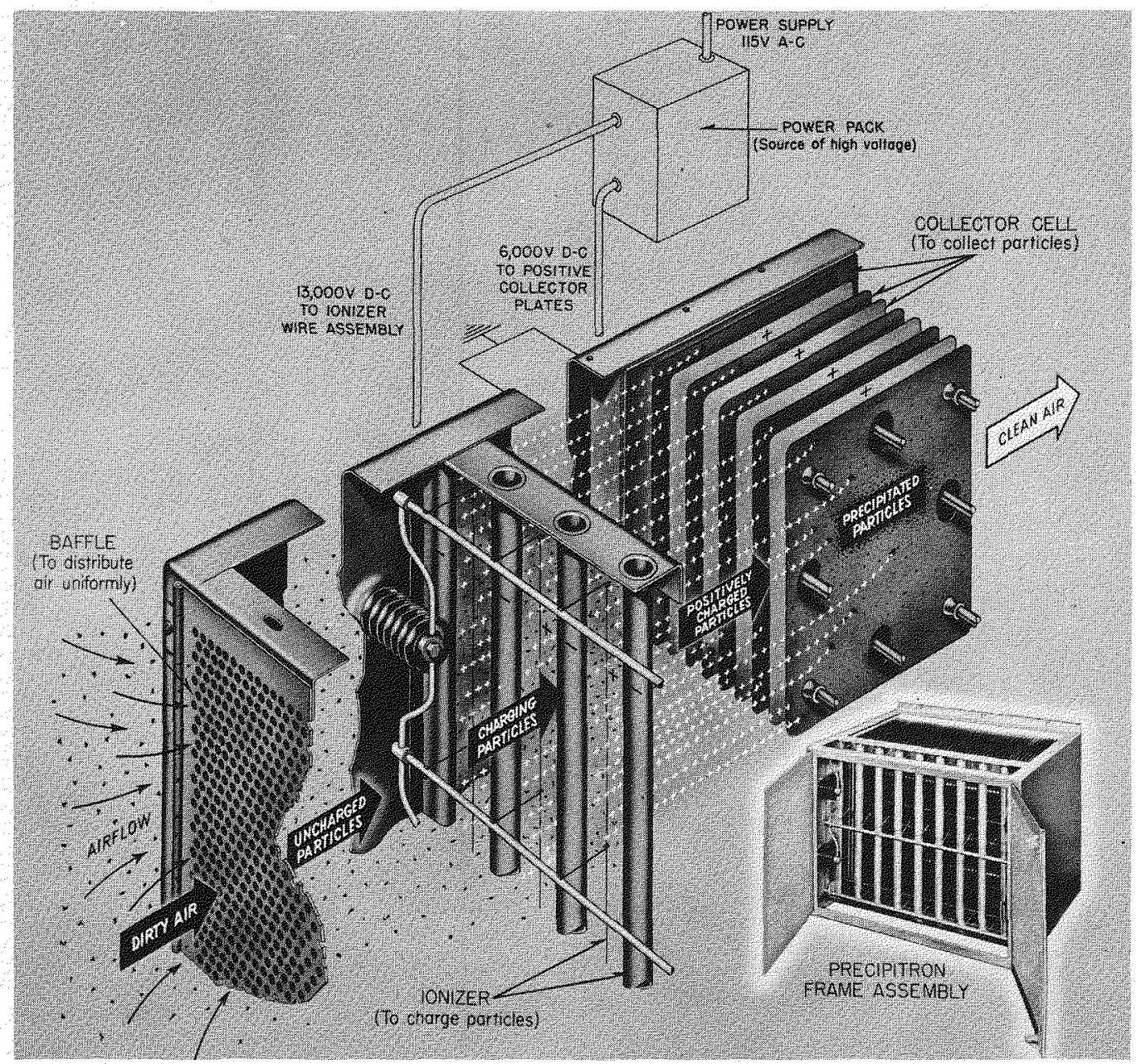

Fig. 2.40-Ionizing and Collecting Sections of Two-Stage Precipitator (Westinghouse Electric Corp.)

25,000 and over, and the two-stage units at about 12,000 volts in the ionizing stage and 6000 in the collecting section. The Cottrells always run with visible coronae and with voltages stepped up close to the point of disruptive discharge. Accidents from electric shock are rare, but the risk is very real. On the other hand, the twostage units used in air conditioning are almost proof against, electric shocks. They give off little of the disagreeable ozone and nitrogen oxides produced by corona discharge in the Cottrells, but must be operated at lower temperatures. Both types offer little resistance to the gas flow.

In the Cottrell precipitators, the discharge electrodes are usually wires of negative polarity. The collecting electrodes are either plates or pipes with the wires hung in central alignment (Figs. 2.36 and 2.37 ). The distance between the 
two terminals is usually 4 to 8 inches. Deposited particulate matter is removed by rapping, or it may be flushed down with water. When handling dry, non-conducting dusts, like silica, efficiencies may gradually drop unless water vapor is introduced like, efficiencies are lower, often below 95\%. It is possible, but expensive, to increase them to the $99+\%$ generally needed in $\mathrm{AEC}$ work.

In the two-stage units, the ionizing section contains a series of grounded tubes

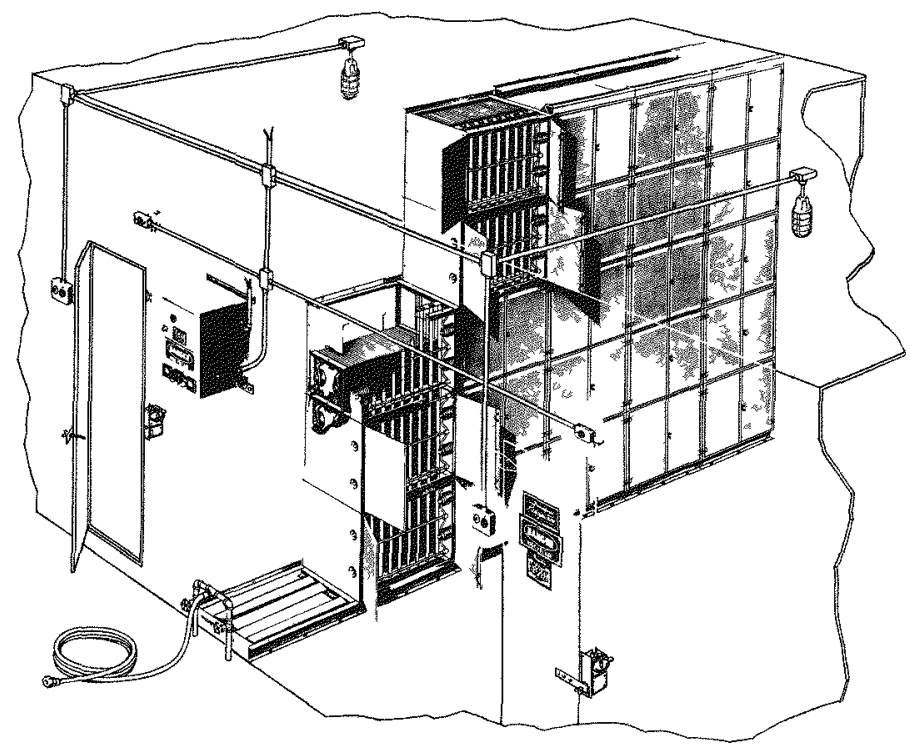

F1g. 2.41 - Installation of Two-Stage Precipitators (Westinghouse Electric Corp.)

to increase the conductivity of the dust layer. On the other hand, Cottrells work very well on conducting mists such as sulfuric acid, and do not lose their efficiency. Whether the precipitator is the plate (Fig. 2.38) or pipe (Fig. 2.39) type depends on the material to be caught.*

Cottrell efficiencies on acid mist can be close to $100 \%$ and generally exceed $98 \%$ but on metallurgical fume, flyash, and the

\footnotetext{
* Plate type precipitators are commonly used for dusts such as flyash and cement suspensions. The pipe type generally handles mists and fumes such as sulfuric acid droplets, tar fog, or sodium carbonate fume. Both types are used on metallurgical fume.
}

alternating with thin discharge wires made of tungsten (Figs. 2.40 and 2.41). The collecting stage consists of parallel plates which may be less than half an inch apart in contrast with the relatively wide spacing in the Cottrells. The plates are usually coated with oil to prevent re-entrainment of the dust; they must be periodically washed by hosing with hot water and then coated with clean oil. Self cleaning units, in which the plates are continuously passed through an oil bath to remove the deposited dust, are also in operation (Fig. 2.42).

Efficiencies of the two-stage precipitators are high, and units with housings 


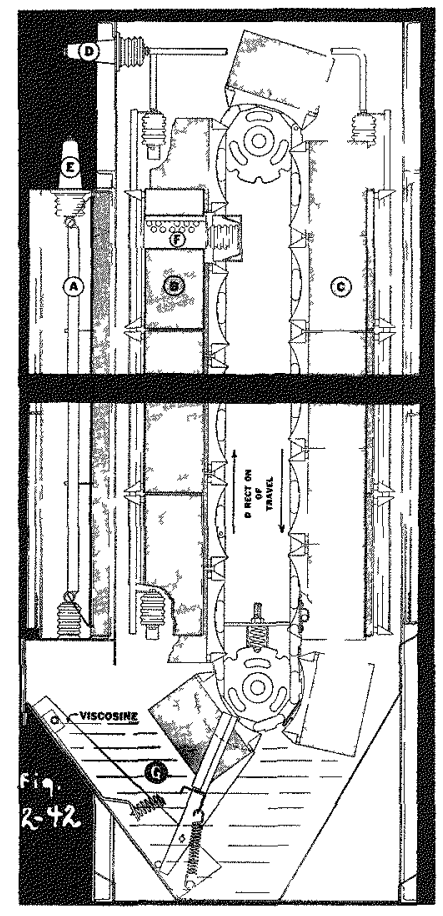

Fig. 2.42-Automatic Two Stage Electric Precipitator - Dirty air passes first through the 1onizing section (A) and then through the front (B) and rear (C) curtains of collecting plates. These plates rotate slowly and pass at regular intervals through the oil bath where they are cleaned. (American Air Filter Co.) especially designed to prevent by-passing of the air have been operated at efficiencies considerably above $99 \%$ (by DOP testChap. III). ${ }^{42}$ However, they are expensive, occasionally arc, and are relatively difficult to handle (as compared with filters). In our opinion, it would be unwise to use them for final cleaning-up unless they are given a thorough trial at pilot plant stage.

A laboratory precipitator using an AC voltage is well known and can be made to operate at efficiencies acceptable for $\mathrm{AEC}$ work. It has never been adapted to handling large air volumes such as we meet in AEC plants and it is doubtful if it can be. It is described fully in Drinker and Hatch $(3, \mathrm{p}$. 126). We have used these precipitators for years, as has the Bureau of Mines, for testing filters and dust respirators and measuring the amount of dust exhaled by man. The units are reliable but the operation is fussy, the risks of shock are considerable, and they may break down completely with a nice display of pyrotechnics. In World War I a smoke mask was made on the precipitator principle but was given up because of these difficulties. 
$-$ 


\section{PERFORMANCE AND EVALUATION OF AIR CLEANING EQUIPMENT}

Air cleaners are rated in terms of cleaning efficiency, resistance or pressure loss, flow rate, velocity, and initial and operating costs. The cleaning efficiency is customarily given in percent, resistance in inches of water gauge, flow rate in cubic feet per minute (CFM), velocity in feet per minute (FPM), and costs in dollars per unit of capacity such as 1 , 10, or 1000 CFM. Tabulations of performance data and costs of air cleaning equipment are presented in this chapter.

Resistance, flow rate, and velocity are simple enough to measure and their meanings are clear. Efficiency, on the other hand, can be interpreted variously and a discussion of its significance is worthwhile.

\section{CLEANING EFFICIENCY}

The ability of a device to remove particulate matter from air is measured by its cleaning efficiency $(\eta)$, also known as the removal or collection efficiency or as the arrestance. Usually it is defined as

$$
\eta=\left(1-c_{e} / c_{i}\right) 100
$$

where $c_{e}=$ effluent concentration

$c_{i}=$ inlet concentration

For collectors of high efficiency, the percent penetration (100 times the ratio of effluent concentration to inlet concentration, i.e., $100-\eta$ ) is more significant.* At a given velocity and pressure loss, cleaning efficiency depends principally on
(1) the nature of the test aerosol and (2) the method of sampling.

\section{The Test Aerosol}

Many test aerosols have been suggested for the rating of equipment performance. The Army and Navy have used methylene blue (MB) smokes and dioctyl phthalate (DOP) fogs for testing filters. ${ }^{43}$ The methylene blue smoke is produced by atomizing a $1 \%$ aqueous solution of the dye and then mixing the mist with a large volume of dry air to evaporate the water. The concentration obtained is about 10 grains $/ 1000$ CF $\left(23 \mathrm{mg} / \mathrm{m}^{3}\right)$ and most of the particles are nearly spherical. Particle size varies depending on the conditions of generation, but a sample examined under the electron microscope at Oak Ridge had a mass median of about 0.7 microns and a standard deviation of 2.4. ${ }^{44}$ The methylene blue test is run at $32 \mathrm{lpm}$ through a $100 \mathrm{~cm}^{2}$ sample of test paper (9.2 FPM).

Homogeneous dioctyl phthalate fog is generated by mixing air containing DOP vapor at $170^{\circ} \mathrm{C}$ and clean air at $25^{\circ} \mathrm{C}$ in a volume ratio of $1: 4$. The concentration is adjusted to about 40 grains/1000 CF (92 $\mathrm{mg} / \mathrm{m}^{3}$ ) and particle size to about $0.3 \mathrm{mi}-$ crons. As with methylene blue, the DOP

*For example, a drop in efficiency from 99.9 to $99.8 \%$ seems negligible, but is equivalent to a $100 \%$ increase in penetration $(0.1$ to $0.2 \%)$. The $A E C$ often uses the decontamination factor (d.f.) (usually defined as $c_{i} / c_{e}$ ) as a measure of efficiency. Thus a penetration of $0.1 \%$ corresponds to a d.f. of $10^{3}$. 
test generally is run at a velocity of 32 $\mathrm{cm}$ sec (9.2 FPM). Under actual operating conditions, paper filters usually are tested at velocities of 4 or 5 FPM.

Some work has been done on synthesizing methylene blue and a thio dioctyl phthalate using radioactive sulfur. ${ }^{43,44}$ It is planned to apply tracer techniques in conjunction with the standard MB discoloration and DOP penetrometer tests.

The Bureau of Standards developed ${ }^{45}$ for the Government a test dust made from flyash (collected from Cottrell precipitators) to which $4 \%$ lampblack was added. The latter represents soot, the most objectionable constituent of ordinary household dust. Particle size varies with the source of the components, but the dust is generally coarse. The apparatus for dispersing the dust into the air stream delivers about 15 grains $/ 1000 \mathrm{CF}\left(35 \mathrm{mg} / \mathrm{m}^{3}\right)$. Air volumes actually passing through the cleaner are those specified by the manufacturer.

The ASHVE (American Society of Heating and Ventilating Engineers) ${ }^{46}$ suggested a test dust containing $50 \%$ lampblack with a minimum of $97.5 \%$ free carbon and a bulking value of at least $3.5 \mathrm{lb} / \mathrm{CF}$, mixed with $50 \%$ of a 200 mesh ash from Pocahontas coal. Here, again, particle size varies but the dust is generally coarse. Concentrations of about 5 grains $/ 1000 \mathrm{CF}$ $\left(11.5 \mathrm{mg} / \mathrm{m}^{3}\right)$ are used.

The Bureau of Mines has a series of testing codes for the filters of dust respirators with test suspensions ranging from tobacco smoke to finely ground mineral dusts $(3$, p.268). Our Air Cleaning Laboratory has described tests using microscopic glass spheres, copper sulfate dusts, and tobacco smoke. ${ }^{47}$ In the past, we have used bacteria, pollens, fumes of lead, zinc oxide, magnesium oxide, and mineral dusts $(3, \mathrm{p} .250)$. During the late war, the U. S. Army used a test dust with a mass median of about 9.2 microns and a standard deviation of 2.8 .

The characteristics of the aerosol which affect the performance of an air cleaning device include concentration, ${ }^{*}$ particle size distribution, shape, density, surface characteristics, and charge. Perhaps the most important of these is the size distribution, and several instruments have been developed for its measurement.

In the cascade impactor (Figs. 3.1 to $3.3)$, the aerosol is passed through a series of four jets set normally to four slides. Since the areas of the jets decrease progressively, the velocity of the gas increases at each jet and successively smaller particles are caught on each slide; those which escape deposition by this method are caught on a fifth stage filter. The slides may be examined under a microscope or the material collected may be analyzed chemically or physically. The mean size deposited at each stage is obtained from a calibration curve of the instrument, and the distribution curve for the aerosol can then be plotted. The cascade impactor is useful for particles larger than about 0.2 microns. Smaller particles of very heavy substances, e.g., $\mathrm{UO}_{2}$, can also be caught.

Hatch ${ }^{48}$ points out some of the limitations of this instrument: "The low sampling rate ( 17.5 liters per minute) requires

\footnotetext{
*For example, increasing inlet loading from a fraction of a grain to above 10 grains CF will cause a considerable increase in cyclone efficiency.
} 


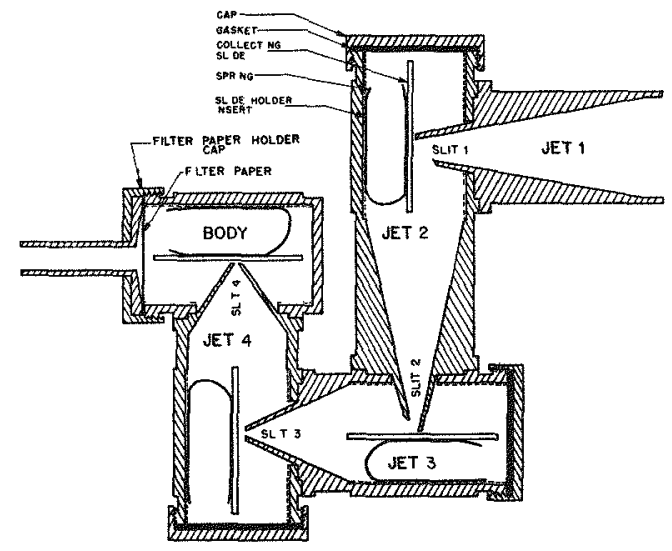

LONG TUERAL SECTIOH

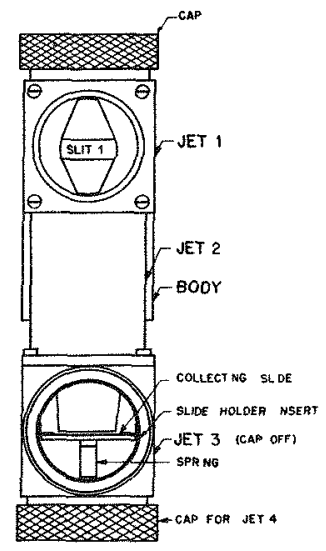

FrONTAL VIE

Fig. 3.1-Assembly Drawing of the Modified Cascade Impactor. ${ }^{51}$

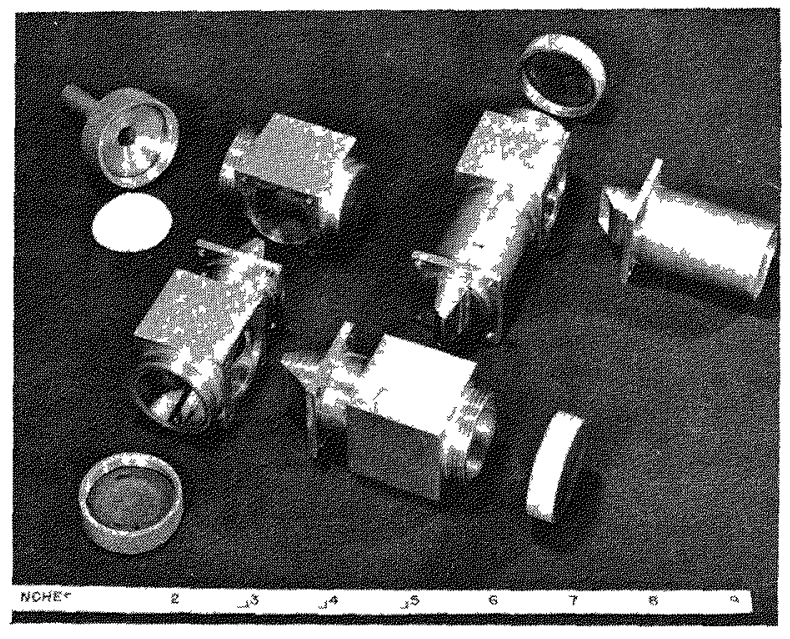

Fig. 3.2-Modified Cascade Impactor - Disassembled unit showing four jets, filter paper stage, screw caps and slide holder..$^{52}$

a long period of sampling to give measurable results when concentrations are within tolerance levels. Since the dust is deposited in a concentrated narrow band, it is not possible to distinguish individual particles by autoradiography because of interference and, possibly, piling up of

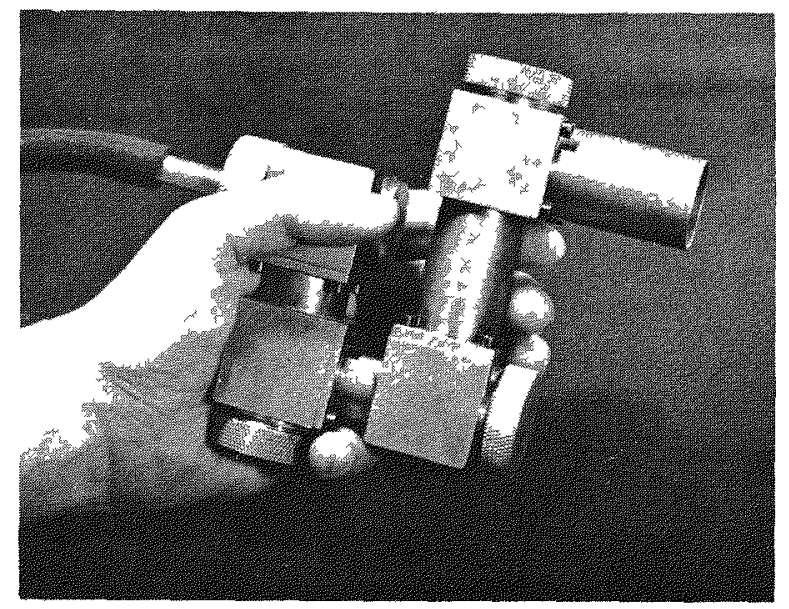

Fig. 3.3-Modified Cascade Impactor. ${ }^{52}$

particles. The adhesive slide coating may interfere with alpha counting. Some dust is deposited on the inner walls of the instrument and it may be difficult to decontaminate. With Iong continued sampling, some of the deposited dust may be blown off the plates."

The thermal precipitator may be used for sizing particles below the effective 
range of the cascade impactor. It is claimed to be $100 \%$ efficient for particles up to 1 or 2 microns and can be used for preparing slides for the electron microscope.* Thermal precipitation is superior to impingement in that the particles move at a low velocity and aggregates are not shattered on striking the collecting plate.

In the standard instrument (Fig. 3.4), the aerosol is passed at a low velocity around an electrically heated wire sus-

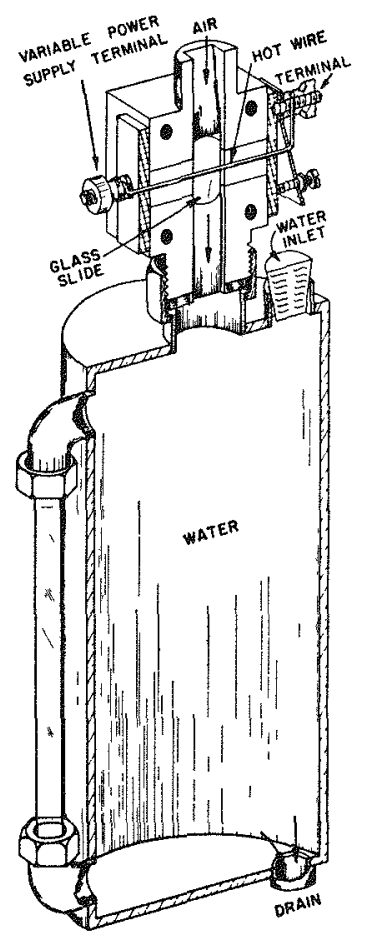

Fig. 3.4-Thermal Precipitator - The sample is drawn past the wire as water drains from the reservoir. ${ }^{53}$

\footnotetext{
* The electron microscope reveals particles as small as 0.001 microns. However, because of the high mag nification, a large number of fields must be examined to obtain a size distribution representative of the aerosol, and counting is an even more laborious task than with the light microscope.
}

pended between two slides. This device is not well suited to sizing because of the non-uniform distribution of the particles on the collecting plate. To circumvent this difficulty, the so-called oscillating thermal precipitator has been developed with a continuously moving collecting surface (Figs. 3.5 and 3.6).$^{49}$

Leary ${ }^{50}$ describes an autoradiographic technique for measuring size distribution of alpha emitters. The slide or filter paper on which the particles are deposited is placed in intimate contact with a nuclear track plate and exposed for a given time. After developing and fixing, the plate is examined under the light microscope. By counting the number of tracks, the size of each emitting particle can be determined.

The method is limited. The particles must be at a high level of alpha activity, and since they are not observed directly, their shape cannot be determined. If there are many large particles, the smaller ones maybe obscured. Finally, the counting of tracks is a tedious job.

\section{The Test Method}

Several general principles of sampling, applicable to all test methods, may be noted: In large ducts, several samples must be taken (as in traverses for measuring air flow), since there is often a considerable variation across the duct. In small ducts, traversing is unnecessary, and the sample can be an appreciable part of the total flow. Withdrawal of the gas should be isokinetic, i.e., at the same velocity as in the duct. Otherwise, there may be a difference in composition between the sample and the original gas. Finally, sampling lines should be as short 


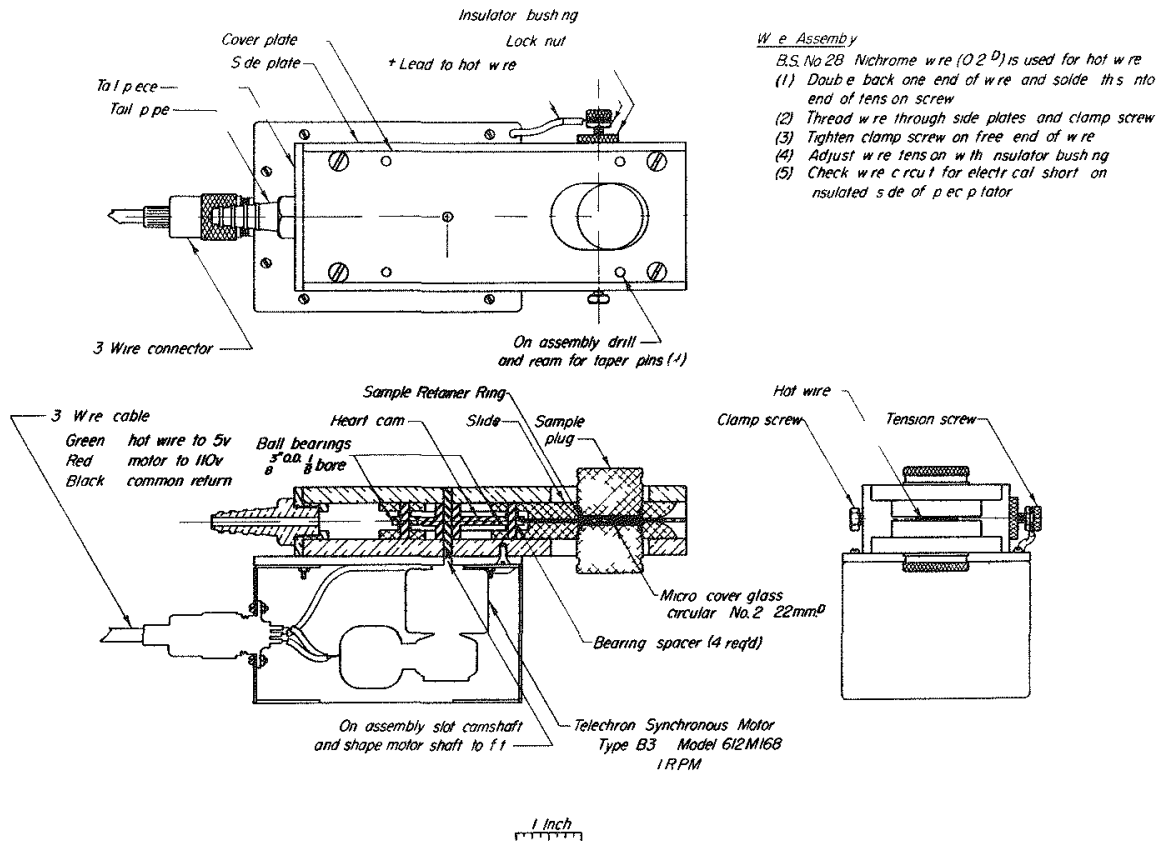

Fig. 3.5-Oscillating Thermal Precipıtator (Unıv. Roch. Atomic Energy Proj.)

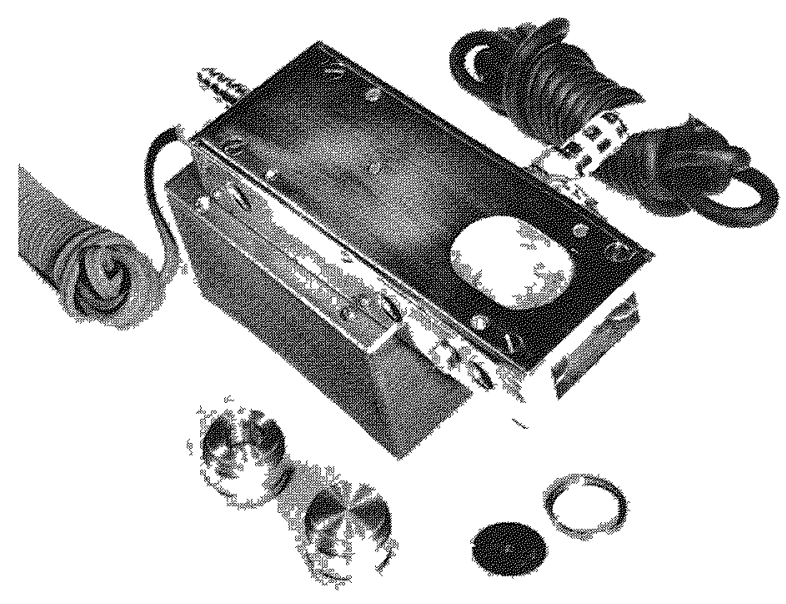

Fig. 3.6-Motor-Driven Oscillating Thermal Precipitator Showing Specimen Holders and Filament. ${ }^{52}$

as possible and free of bends, enlargements, valves, etc., to prevent removal by inertial forces or settling.

Many instruments are in use for meas- uring the concentration of particulate matter. Some are mentioned in the following discussion while information on others is given by Drinker and Hatch (3, p. 91) and Stokinger and Laskin. ${ }^{52}$ In Table 3.1 , adapted from Silverman, ${ }^{54}$ the devices are grouped according to the method of collection. Some of their advantages and disadvantages are pointed out, and references from which more detailed information can be obtained are listed. The test methods employing these instruments are based on (a) weight, (b) discoloring or staining power, (c) count, or (d) radioactivity of the particles.

1. Tests Based on Weight. Tests based on the weight of material removed are particularly useful for heavy loadings of dry dusts. Efficiency by weight is a function of volume, and a 10 micron particle, for example, is equivalent to a thousand 
Table 3.1-A Comparison of Devices Commonly Used for Aerosol Sampling

\section{Principle of} method and instrument

(Sedimentation) Settling pan

Sedimentation cell

(Inertial and
centrifugal)
$(4 a b r i t h$

Labyrinth

Midget cyclone

Aerotec tube design 2

(Impingement -

impaction and

jet condensa-

tion)

Owens

Konimeter

Bausch and

Lomb

Impinger

Cascade

impactor
Sample

$\underset{\text { rate }}{\text { Sampling }}$

Per cent

Particle size

range (microns)

High-low

10-mesh-

variable

10-mesh-0.2

$50 \mathrm{ml}$

100
Large

Variable

Large

25-50 cfm

98

Large

$35 \mathrm{cfm}$

94

50-100 m

$50-100$

Instantaneous

99

10-0.2

10-mesh-1

10-mesh-5

10-mesh-5

$2.5-5 \mathrm{ml}$

$$
\text { small }
$$

Instantaneous

$0.01 \mathrm{cu}$

Medium

$1 \mathrm{cfm}$

Small

$17 \mathrm{lpm}$

$100-0.2$
Method of

quantitation

References

Weight, count, Shaw and Owens, "The Smoke or chemical problem of Great Cities," anaiysis

Constable \& Co., London, 1925.

Green, J. Indust. Hyg., 16: $29,1934$.

Briscoe et al., Trans. Inst. Min. and Met., June, 1937

Weight, count, or chemical

1933.

The Thermix Corporation, Greenwich, Conn., 1949.

Jacobs, "The Analytical Chemistry of Industrial Poisons, Hazards and Solvents, Interscience, New York, 1941.

Brown, Schrenk, and Little-
field, U.S. Bureau of field, U.S. Bureau of Mines Information Circular 6993, February 1938.

Gurney, Williams, and Meigs, Modified Owens with simplified darkJ. Ind. Hyg. \& Tox., 20: 24, 1938.

Count

Count, weight,
or chemical
Pub. Health Bull. No. 217

Count, weight,
or chemical
Pub. Health Bull. No. 217, Wash., D.C., 1935.

field counting microscope integral with instrument.

Adapted to low concentrations only. Particle sizing may be done directly on slide.

Adapted to low concentrations only

If operated at sonic nozzle velocity, ef ficiency for particles as small as 0.1 microns is reportedly $100 \%$. Can be used for readily soluble gases.

Count or

May, J.S.I., 22: 187, 1945; Sonkin, J. Ind. Hyg. \& Tox. provides a rapid means of fractionatin chemical

aerosol by terminal velocity. Not well adapted to high concentrations if slides are to be counted. 


\begin{tabular}{|c|c|c|c|c|c|c|c|}
\hline $\begin{array}{l}\text { Paper } \\
\text { thimble }\end{array}$ & & $1-3 \mathrm{cfm}$ & 95 & $10-$ mesh -0.2 & Weight & $\begin{array}{l}\text { Brady and Touzalin, Ind. Eng. } \\
\text { Chem., 3: 662, } 1911 .\end{array}$ & $\begin{array}{l}\text { Not adapted to high temperatures or } \\
\text { moist atmospheres. }\end{array}$ \\
\hline $\begin{array}{l}\text { Paper disks } \\
\text { or pleated } \\
\text { paper }\end{array}$ & $\begin{array}{l}\text { Small, } \\
\text { Medium, } \\
\text { or large }\end{array}$ & $\begin{array}{l}1-3 \mathrm{cfm} \\
40-60 \mathrm{cfm}\end{array}$ & 99 & $10-$ mesh -0.2 & Weight & $\begin{array}{l}\text { Katz and Smith, U.S. Bureau } \\
\text { Mines, Rep't of Invest. } \\
2378,1922 .\end{array}$ & $\begin{array}{l}\text { Can measure quantitatively by dis- } \\
\text { coloration in low concentrations. } \\
\text { s"Tar Camera," ASHVE, U.S. Bur. of } \\
\text { Stand. use modifications. }\end{array}$ \\
\hline $\begin{array}{r}\text { Cotton, wool, or } \\
\text { asbestos bags }\end{array}$ & Large & $10-50 \mathrm{cfm}$ & 99 & 10 - mesh-1 & Weight & $\begin{array}{l}\text { Bubar, H.H., "Bagtest Sam- } \\
\text { pler," Old Lynne, Conn. }\end{array}$ & $\begin{array}{l}\text { Life is limited and handling of sample } \\
\text { for particle sizing is difficult. } \\
\text { Primarily adapted to weight de- } \\
\text { termination. }\end{array}$ \\
\hline $\begin{array}{l}\text { Glass fibers, } \\
\text { cloth, or } \\
\text { alundum } \\
\text { thimbles }\end{array}$ & $\begin{array}{l}\text { Small, } \\
\text { medium, } \\
\text { or large }\end{array}$ & $1-3 \mathrm{cfm}$ & $90-95$ & 10 -mesh-1 & Weight & $\begin{array}{l}\text { Western Precipn. Corp. Bull. } \\
\text { WP } 50,1948 \text {. }\end{array}$ & $\begin{array}{l}\text { Alundum filters possess high flow re- } \\
\text { sistance. Glass cloth and fibers may } \\
\text { have low efficiency if not fine fibers } \\
\text { or well packed. Glass filters (Shotts) } \\
\text { appear to give good results. }\end{array}$ \\
\hline $\begin{array}{l}\text { Molecular } \\
\text { filter }\end{array}$ & Small & $1 \mathrm{cfm}$ & $\begin{array}{l}\text { approaches } \\
100\end{array}$ & $>0.01$ & $\begin{array}{l}\text { Count, weight, } \\
\text { or chemical }\end{array}$ & $\begin{array}{l}\text { Prof. A. Goetz, Calif. Inst. } \\
\text { Tech. }\end{array}$ & $\begin{array}{l}\text { A plastic material not intended for hot } \\
\text { gases or gases containing organic } \\
\text { solvents; can be mounted directly in } \\
\text { microscope. Pressure drop is high. }\end{array}$ \\
\hline $\begin{array}{l}\text { Wire screen } \\
\text { or gauge }\end{array}$ & Large & $1-10 \mathrm{cfm}$ & $50-70$ & 10 -mesh-10 & Weight & $\begin{array}{l}\text { Hardie, P.H., Trans. ASME, } \\
\text { 59: 355, } 1937 \text {. }\end{array}$ & $\begin{array}{l}\text { Material for screen is } 400 \text {-mesh cloth, } \\
\text { which is expensive. Efficiency is } \\
\text { variable. Not satisfactory for fine } \\
\text { materials until bed is accumulated. }\end{array}$ \\
\hline $\begin{array}{l}\text { Volatile or } \\
\text { soluble } \\
\text { crystals }\end{array}$ & $\begin{array}{l}\text { Small, } \\
\text { medium, } \\
\text { or large }\end{array}$ & $1-30 \mathrm{~cm}$ & $35-90$ & 10 -mesh -0.2 & $\begin{array}{l}\text { Weight or } \\
\text { chemical }\end{array}$ & $\begin{array}{l}\text { Matthews, Analyst, } 63: 467 \text {, } \\
\text { 1938. }\end{array}$ & $\begin{array}{l}\text { Not adapted to high temperatures. Ind. } \\
\text { Hyg. Found. has modified method } \\
\text { for high volume sampling. }\end{array}$ \\
\hline $\begin{array}{l}\text { (Washing or } \\
\text { scrubbing) }\end{array}$ & a & & & & & & \\
\hline $\begin{array}{l}\text { Simple } \\
\text { bubbling } \\
\text { devices }\end{array}$ & Small & $0.5-1 \mathrm{cfm}$ & $90-95$ & 10-mesh-10 & & $\begin{array}{l}\text { Silverman, "Industrial Air } \\
\text { Sampling and Analysis," } \\
\text { Chem. \& Tox. Bull. No. 1. }\end{array}$ & $\begin{array}{l}\text { Efficiency low for particulate material } \\
\text { unless it is very coarse. Efficiency } \\
\text { for gases is dependent on their solu- } \\
\text { bility and rate of reaction. }\end{array}$ \\
\hline $\begin{array}{l}\text { Sintered } \\
\text { glass } \\
\text { absorbers }\end{array}$ & Small & $0.1-0.5 \mathrm{cfm}$ & 95 & $10-0.2$ & $\begin{array}{l}\text { Weight or } \\
\text { chemical }\end{array}$ & $\begin{array}{l}\text { Silverman, "Industrial Air } \\
\text { Sampling and Analysis," } \\
\text { Chem. \& Tox. Bull. No. 1. }\end{array}$ & $\begin{array}{l}\text { Highest efficiency devices for gases. } \\
\text { For particulate material rate must } \\
\text { be kept low. Porosity of sintered } \\
\text { glass affects efficiency since separa- } \\
\text { tion is due to filtration and scrubbing. }\end{array}$ \\
\hline $\begin{array}{l}\text { Wetted packed } \\
\text { towers (bead } \\
\text { columns, etc.) }\end{array}$ & Medium & $1-3 \mathrm{cfm}$ & $90-95$ & $10-$ mesh-10 & & $\begin{array}{l}\text { Silverman, "Industrial Air } \\
\text { Sampling and Analysis," } \\
\text { Chem. \& Tox. Bull. No. 1. }\end{array}$ & $\begin{array}{l}\text { Efficiency depends on solubility and } \\
\text { reactivity of gas and absorbent. } \\
\text { Particulate material is retained in } \\
\text { proportion to porosity of packing and } \\
\text { velocity. }\end{array}$ \\
\hline $\begin{array}{l}\text { Venturi } \\
\text { scrubber }\end{array}$ & Large & $30-40 \mathrm{cfm}$ & $90-95$ & 10 -mesh-0.2 & & $\begin{array}{l}\text { Magill, Stanford Res. Inst. } \\
\text { 1949; Collins, Seaborne, } \\
\text { and Anthony, Paper Trade } \\
\text { J., Jan. 15, 1948. }\end{array}$ & $\begin{array}{l}\text { This is a portable device using the } \\
\text { principle of the Pease-Anthony unit. } \\
\text { The collecting medium is recirculated. } \\
\text { Adapted to both gaseous and particu- } \\
\text { late material but the bases should be } \\
\text { readily soluble. }\end{array}$ \\
\hline
\end{tabular}


Tabie 3.1-(Cont'd.)

\begin{tabular}{|c|c|c|c|c|c|c|c|}
\hline $\begin{array}{l}\text { Principle of } \\
\text { method and } \\
\text { instrument }\end{array}$ & $\begin{array}{l}\text { Sample } \\
\text { volume }\end{array}$ & $\begin{array}{l}\text { Sampling } \\
\text { rate }\end{array}$ & $\begin{array}{l}\text { Per cent } \\
\text { efficiency }\end{array}$ & $\begin{array}{c}\text { Particle size } \\
\text { range (microns) }\end{array}$ & $\begin{array}{l}\text { Method of } \\
\text { quantitation }\end{array}$ & References & Remarks \\
\hline \multicolumn{8}{|l|}{$\begin{array}{l}\text { (Thermal } \\
\text { precipitation) }\end{array}$} \\
\hline $\begin{array}{l}\text { Thermal pre- } \\
\text { cipitator }\end{array}$ & Small & $5-10 \mathrm{ml} / \mathrm{min}$ & $\begin{array}{l}\text { approaches } \\
100\end{array}$ & $>0.001$ & Count & $\begin{array}{l}\text { Watson, Trans. Faraday } \\
\text { Soc. } \underline{32}: 1073,1936 .\end{array}$ & $\begin{array}{l}\text { Not adapted to high concentrations or } \\
\text { large particles. Excellent for parti- } \\
\text { cle sizing including electron micro- } \\
\text { graph work. }\end{array}$ \\
\hline \multicolumn{8}{|l|}{$\begin{array}{l}\text { (Electrical } \\
\text { precipitation) }\end{array}$} \\
\hline $\begin{array}{l}\text { Electric } \\
\text { precipitator }\end{array}$ & $\begin{array}{l}\text { Small, } \\
\text { medium, } \\
\text { or large }\end{array}$ & $1-3 \mathrm{cfm}$ & 99 & 80 microns -0.2 & $\begin{array}{l}\text { Count, weight, } \\
\text { or chemical }\end{array}$ & $\begin{array}{l}\text { Drinker and Hatch (cited } \\
\text { above); Western Precip. } \\
\text { Corp. (cited above). }\end{array}$ & $\begin{array}{l}\text { May be used in A.C. or D. C. form. } \\
\text { D.C. is more practical for field use } \\
\text { and requires less voltage. For hot } \\
\text { gases arcing becomes a problem. } \\
\text { Large particles may not be trapped } \\
\text { but precleaner can be used in series. }\end{array}$ \\
\hline \multicolumn{8}{|l|}{ (Optical) } \\
\hline Penetrometer & Small & $32 \mathrm{lpm}$ & $\begin{array}{l}\text { Direct } \\
\text { reading }\end{array}$ & 0.3 & $\begin{array}{l}\text { Light } \\
\text { scattering }\end{array}$ & $\begin{array}{l}\text { Gucker, F.T., Jr., Pickard, } \\
\text { H.B., and O'Konski, C.T., } \\
\text { "'Methods of Testing } \\
\text { Smoke Filters," Handbook } \\
\text { on Aerosols, p. 122, USAEC, } \\
\text { Wash., D.C., 1950. }\end{array}$ & $\begin{array}{l}\text { Sensitive to penetrations as low as } \\
0.001 \% \text {. Some types count individual } \\
\text { particles. Aerosol must be homo- } \\
\text { geneous, and at a low concentration. }\end{array}$ \\
\hline
\end{tabular}
Aerosols, p. 122, USAEC 
of the 1 micron size (or the same material). Since air cleaning devices generally are more effective for the larger particles, efficiencies by weight are apt to be higher than those determined in other ways. For homogeneous aerosols (seldom encountered in practice), efficiencies determined by the various methods are substantially the same.

The ASHVE test dust has been used widely by manufacturers of air cleaning equipment, especially viscous filters. Whatever the test suspension, the particulate matter usually is collected on paper filters in such forms as disks, thimbles, or pleated cones (Fig. 3.7). Glass or ceramic materials may be substituted for paper if the gases are hot or moist. We have used the "molecular" filter for uranium trioxide, copper sulfate, and atmospheric dusts with good results. Pressure drop is high, but efficiency approaches $100 \%$. Moreover, the material collects on the surface and can be examined with a microscope or analyzed chemically - neither of which may be possible with a porous filter.

Laboratory electric precipitators (Fig. 3.8) are easy to make and are very efficient for even the smallest particles. They are suitable for low loadings (below 1 grain/1000 CF or $2.3 \mathrm{mg} / \mathrm{m}^{3}$ ) if the particulate can be analyzed chemically or physically. However, they are not intended for easily oxidizable substances, e.g., $\mathrm{UF}_{4}$ which reacts to form $\mathrm{UO}_{2} \mathrm{~F}_{2}$.

Several instruments have been developed for the rapid isokinetic sampling of stack gases or of gases flowing through ducts. ${ }^{55,56}$ At our Laboratory, the instrument shown in Fig. 3.9 is often employed for loadings above 0.1 grain $\mathrm{CF}\left(230 \mathrm{mg} / \mathrm{m}^{3}\right)$, provided most of the particles are larger than 1 micron. The device has six interchange- able sampling nozzles - three each for upstream and downstream of the cleaner. Each set is calibrated against the rotameter for velocities of 2500,3500 , and 4500 FPM at flow rates of 1 CFM upstream and 3 CFM downstream. These velocities were chosen since, in industrial practice, conveying velocities for particulate matter generally range from 2000 to 5000 FPM. After measuring the duct velocity with a pitot tube, the sampling head with the velocity closest to the measured value is inserted.

For very low concentrations, high volume samplers operating at 50 to $70 \mathrm{CFM}$ have been developed.5\% They can collect enough material for a weight analysis of normal city air in an hour or less, but it is usually not possible to operate them isokinetically.

2. Tests Based on Discoloring Power. The discoloration tests are simple and rapid, but results are often not reproducible. They consist of comparing with a series of known standards the stain produced on a filter paper by the effluent from the device under test. The standards are made by staining papers with different volumes of untreated aerosol. Comparisons can be made either visually or by a densitometer, and penetration is given by the ratio: (volume through the standard/volume of treated aerosol required for a stain of the same intensity as the standard). Discoloration efficiencies usually fall between those by weight and by count.

As already noted, the Army and Navy have used methylene blue smoke for testing filters. Manufacturers, particularly of electric precipitators, frequently quote discoloration efficiencies determined with the NBS test dust or with ordinary air. 


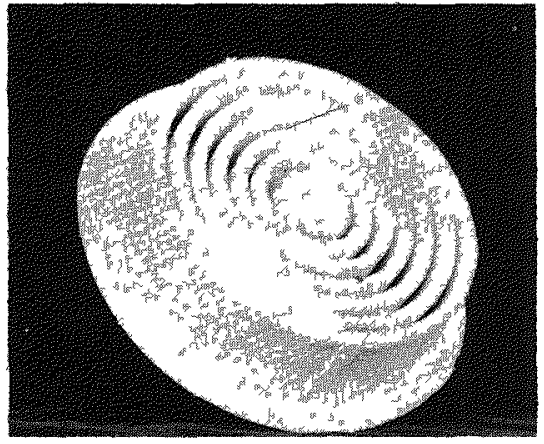

Fig. 3.7-Pleated Paper Filter - The large surface area permits high flow rates at moderate resistances.

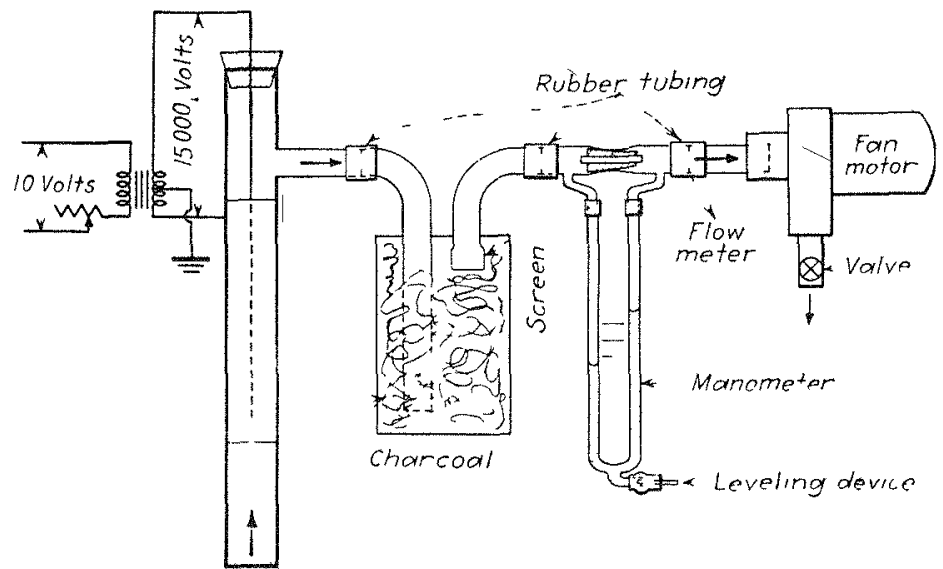

Fig. 3.8-Laboratory AC Electric Precipitator - The charcoal trap absorbs ozone from the gases leaving the precipitator. $(3$, p. 126)

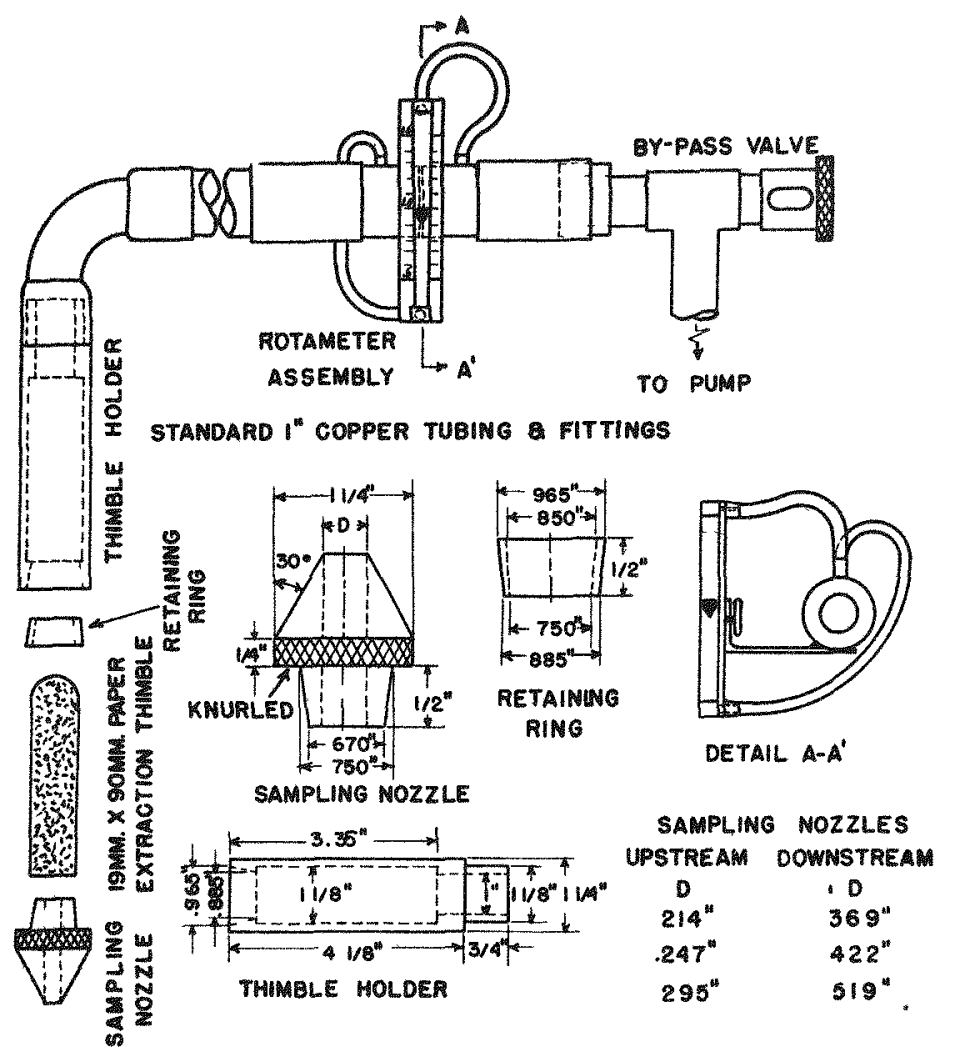

Fig. 3.9-Stack Sampling Unıt for Isokinetic Field Sampling. 
Tests with ordinary air are more exacting than those with the NBS dust, which is usually rather coarse. However, atmospheric dust may vary considerably in different areas and on different days. Since each of these three aerosols is heterogeneous and since the velocities through the standard and test papers often differ, the discoloration method gives only a relative measure of penetration or efficiency from test to test.

3. Tests Based on Count. Sampling methods based on a count of the particles are generally selected when loadings are low. Thus they are particularly suitable for testing collectors of high efficiency. Efficiencies by countare usually the most exacting measure of a collector's performance since large and small particles are rated equally.

The particles can be counted either by means of a microscope or by light scattering techniques. Microscope count tests are not used as often as those depending on weight or discoloration since counting is tedious, time consuming, and sometimes inaccurate. In most cases, the particles are deposited on a slide by one of the impingement devices. These instruments are of limited capacity and are often unsuited to isokinetic sampling. They are seldom effective for particles smaller than about 0.2 micron; moreover, the slides commonly are studied with a light microscope which has a limit of resolution of about 0.3 micron. Thus a large number of very small particles remain uncounted. While these contribute little to the weight of most aerosols, recent work at Oak Ridge indicates that a substantial amount of activity may be associated with particles smaller than $0.5 \mathrm{mi}-$ cron. ${ }^{48}$

The thermal precipitator may be used for determining concentrations of particles in the electron microscope range, but it suffers the serious disadvantage of a very low sampling rate. The electric precipitator is not well suited to sampling for a count analysis because of the nonuniform distribution of the particles on the collecting plate and because of the formation of aggregates.

Photoelectronic penetrometers ${ }^{58}$ have been designed for measuring the intensity of the light scattered by the particles of a test aerosol, generally a homogeneous fog such as dioctyl phthalate. The instrument is adjusted to read $100 \%$ penetration for the untreated aerosol. Since the fog is homogeneous, the intensity of the scattered light is proportional to its concentration (weight or count), and the reading for the filtered aerosol is equal to the penetration.

Penetrometer measurements with dioctyl phthalate are superseding discoloration tests with methylene blue. Penetrometer tests give instantaneous values for the effluent concentrations, are sensitive to penetrations as low as $0.001 \%$, and are more exacting than the methylene blue tests. However, running time must be short since oil fogs like dioctyl phthalate tend to destroy the effectiveness of the filter. * There may be a maintenance problem with the penetrometer, a fairly complex device.

4. Tests Based on Radioactivity. At AEC sites, air cleaning devices are often rated according to their effectiveness in

*It is theorized that the fine fibers are wetted and drawn together by surface tension forces thus leaving open passages through the filter. 
reducing the radioactivity of an aerosol. Efficiencies are determined by measuring the activities of sampling filter papers with an instrument such as the Geiger counter or, for alpha radiation, the scintillation counter. The paper must have a simple geometric shape (such as a disk) since representative counts are difficult to obtain from thimble shaped or pleated filters. Table 3.2 compares penetrations of various Whatman sampling papers.

Hatch $^{48}$ discusses some of the disadvantages of sampling radioactive aerosols with paper filters: the technique is open to error since (a) the filter may aüsorb fission products of near molecular size which are not properly included in a study of particulate activity, and (b) some of the alpha radiation may be absorbed by the filter material. For this reason, it may be desirable to use the relatively inefficient, but hard surfaced Whatman 41 paper in preference to the thick, porous CC-6 medium. ${ }^{*}$ Eisenbud ${ }^{48}$ reported a $30 \%$ absorption loss for coarse uranium dust collected on Whatman 41 paper, but this figure varies with the type of dust and with the filter paper. Alpha ray absorption results in too high a value for the calculated efficiency; the reduced concentration and particle size downstream permitgreater penetration of the particles into the fibers of the sampling paper and, consequently, proportionally greater alpha absorption as compared with the upstream sample.

\footnotetext{
* Plans have been made to use the molecular filter for sampling radioactive aerosols. Since practically all of the particles are caught on the surface of the filter, alpha absorption is not expected to be a serious problem.
}

Efficiencies by weight, count, or discoloration do not necessarily give an accurate picture of the reduction in radioactivity of an aerosol composed of several materials as, for example, the pile cooling air at Oak Ridge (Chap. IV). For a suspension composed of only one substance, efficiency by radioactivity is about the same as that by weight. Specific activities for various materials are given in Table 3.3 to simplify conversions between loadings by weight and by radioactivity.

\section{TABULATIONS OF PERFORMANCE DATA}

Many of the data presented in the following Tables 3.4 to 3.7 , inclusive, were obtained in practical field tests by our Air Cleaning Laboratory. Other figures were taken from the literature, from manufacturers' catalogs, and from replies to a survey conducted by the Laboratory. The source of each set of data is indicated in the first column of the table. We intend to supplement these figures and revise them from time to time.

When available, penetration values and effluent concentrations are given for collectors of high efficiency. Particle sizes refer to the diameter and are generally the mass medians, i.e., that size for which the weight of all larger particles is equal to the weight of all smaller particles. Weight concentrations are given in grains per cubic foot or 1000 cubic feet since these are the terms commonly used by manufacturers of air cleaning equipment. Better units, perhaps, are milligrams per cubic meter (micrograms per liter or micro-ounces per cubic foot). One grain per 1000 cubic feet is equal to 2.3 times each of these'units. The various test aer- 
Table 3.2-Penetrations of Whatman Papers

A. Dioctyl phthalate test aeroso $1^{44}$

\begin{tabular}{|c|c|}
\hline Type & \% Penetration \\
\hline 44 & 0.017 \\
\hline 50 & 0.024 \\
\hline 42 & 0.31 \\
\hline
\end{tabular}

For types $1,2,5,30,40,41,52$, and 54 , penetrations were greater than $1 \%$

B. A lead fume test aerosol was produced by burning a lead tetraethyl solution in alcohol. Efficiencies were determined with a laboratory AC electric precipitator ${ }^{59}$

\begin{tabular}{ccccc} 
Type & $\begin{array}{c}\text { Superficial } \\
\text { velocity } \\
\text { FPM }\end{array}$ & $\begin{array}{c}\text { Concentration } \\
\mathrm{mg} / \mathrm{m}^{3}\end{array}$ & $\begin{array}{c}\text { Penetration } \\
\text { weight \% }\end{array}$ \\
\cline { 1 - 1 } 42 & 15.5 & & 2.17 & \\
42 & 30 & & 1.41 & \\
43 & 16.8 & & 3.05 & 7.7 \\
44 & 13.9 & 1.97 & 9.5 \\
50 & 15.6 & 1.83 & & 4.0 \\
& & & & 16.6
\end{tabular}

* The filter paper was $8.25 \mathrm{~cm}$ in diameter and was backed by a plate perforated with $3 / 16$ " holes over the entire filter paper area.

osols and methods for determining efficiency are discussed in Part $A$ of this chapter.

\section{COST DATA}

Most of the cost data given in this section were obtained from manufacturers of air cleaning equipment. Although we have tried to give the latest figures available, rapidly changing prices will undoubtedly make frequent revisions necessary.

The data are divided into initial and operating costs. The former are given per CFM or, for some cloth filters, per $\mathrm{sq} \mathrm{ft}$ of cloth area or ton of material collected. The latter are usually in dollars/ CFM/year. Other cost figures are given by Lapple ${ }^{5}$ and Carrier, Cherne, and Grant (34, p. 227).

Table 3.3 - Relationship Between Activity, Half Life and Mass

\begin{tabular}{llll} 
Isotope & \multicolumn{1}{c}{ Half life } & \multicolumn{1}{c}{$\begin{array}{l}\text { Grams } \\
\text { per curie }\end{array}$} & $\begin{array}{l}\text { Curies } \\
\text { per gram }\end{array}$ \\
$\mathrm{U}-238$ & $4.51 \times 10^{9} \mathrm{yr}$ & $2,930,000$ & $0.34 \times 10^{-6}$ \\
$\mathrm{Pu}-239$ & $24,100 \mathrm{yr}$ & 15.7 & 0.0636 \\
$\mathrm{Cs}-135$ & $20,000 \mathrm{yr}$ & 7.5 & 0.13 \\
$\mathrm{Ra}-226$ & $1,622 \mathrm{yr}$ & 1.0 & 1.0 \\
$\mathrm{C}-14$ & $5,100 \mathrm{yr}$ & 0.19 & 5.3 \\
$\mathrm{Sr}-90$ & $25 \mathrm{yr}$ & 0.0061 & 160 \\
$\mathrm{Sr}-89$ & $53 \mathrm{days}$ & 0.000036 & 27,800 \\
$\mathrm{P}-32$ & $14.3 \mathrm{days}$ & 0.0000034 & 294,000 \\
$\mathrm{I}-131$ & $8 \mathrm{days}$ & 0.0000078 & 130,000 \\
$\mathrm{Na}-24$ & $14.8 \mathrm{hr}$ & 0.00000011 & $9,100,000$ \\
$\mathrm{~A}-41$ & $110 \mathrm{~min}$ & 0.000000023 & $43.5 \times 10^{6}$ \\
$\mathrm{~N}-16$ & $7.35 \mathrm{sec}$ & $10 \times 10^{-12}$ & $0.1 \times 10^{12}$ \\
$\mathrm{Po}-212$ & $0.000,0007 \mathrm{sec}$ & $5.5 \times 10^{-18}$ & $0.18 \times 10^{18}$
\end{tabular}

\section{Cyclones}

1. Initial Costs. Initial costs for cyclones range from about $\$ .04$ to $\$ .08 /$ CFM for large units to $\$ .25 / C F M$ and higher for small, multitube units. For the type $\mathrm{D}$ Rotoclone, a centrifugal separator with a built-in fan, costs (mid 1950) range from $\$ .12$ to $\$ .18 / C$ M for flow rates from 5000 to $15,000 \mathrm{CFM}$ These figures do not include charges for freight, duct work, erection, or accessory equipment like motors and drives.

2. Operating Costs. Power requirements can be calculated from the follow- 


\begin{tabular}{|c|c|c|c|c|c|c|c|c|c|c|}
\hline & & & & Table $3.4-c$ & yclones & & & & & \\
\hline Device & Manufacturer & Test aerosol & $\begin{array}{c}\text { Inlet } \\
\text { concentration } \\
\text { grains } / \mathrm{CF}\end{array}$ & $\begin{array}{l}\text { Particle size } \\
\text { at inlet } \\
\text { microns } \\
\text { (mass median) }\end{array}$ & $\begin{array}{l}\text { Particle size } \\
\text { at exit } \\
\text { microns } \\
\text { (mass median) }\end{array}$ & $\begin{array}{c}\text { Efficiency } \\
\text { weight \% }\end{array}$ & $\begin{array}{c}\text { Resistance } \\
\mathrm{H}_{2} \mathrm{O}\end{array}$ & $\begin{array}{l}\text { Inlet } \\
\text { velocity } \\
\text { FPM }\end{array}$ & $\begin{array}{l}\text { Flow rate } \\
\text { CFM }\end{array}$ & Remarks \\
\hline $\begin{array}{l}\text { Two cyclones } \\
\text { in parallel }\end{array}$ & & $\begin{array}{l}\text { Silicon carbide } \\
\text { and aluminum oxide } \\
\text { dust from abrasive } \\
\text { stick trimming and } \\
\text { shaping operations }\end{array}$ & 1.76 & & 9.1 & 51 & & & 3280 & \\
\hline Cyclone & & $\begin{array}{l}\text { Silicon carbide } \\
\text { and aluminum oxide } \\
\text { dust in air from } \\
\text { truing and shaping } \\
\text { of abrassive products }\end{array}$ & 0.36 & 10.6 & 5.8 & 58 & & 6180 & 6180 & $\begin{array}{l}7^{\prime} \text { diameter. } \\
\text { Tangential inle } \\
\text { and outlet ducts }\end{array}$ \\
\hline Cyclone & $\begin{array}{l}\text { American } \\
\text { Blower Corp. }\end{array}$ & $\begin{array}{l}\text { Dust laden air from } \\
\text { sand and gravel } \\
\text { bucket elevators, } \\
\text { drying kiln, screen- } \\
\text { ing tower and hot } \\
\text { asphalt mixing } \\
\text { operations }\end{array}$ & 38 & 8.5 & 7.1 & 86 & 1.9 & 2000 & 12,300 & $\begin{array}{l}9^{\prime} \text { in diameter. } \\
\text { Gas at } 240^{\circ} \mathrm{F} .\end{array}$ \\
\hline $\begin{array}{l}\text { Sirocco no. } 20 \\
\text { cyclone } \\
(60)\end{array}$ & $\begin{array}{l}\text { American } \\
\text { Blower Corp. }\end{array}$ & $\begin{array}{l}\text { Air from stone } \\
\text { drying kiln }\end{array}$ & 16.8 & 5.1 & 1.3 & 86 & & 1700 & 4600 & Gas at $230^{\circ} \mathrm{F}$. \\
\hline $\begin{array}{l}\text { Siroceo no. } 20 \\
\text { cyclone } \\
(60)\end{array}$ & $\begin{array}{l}\text { American } \\
\text { Blower Corp. }\end{array}$ & $\begin{array}{l}\text { Air from sand } \\
\text { drying kiln }\end{array}$ & 18.7 & 6.3 & 2.5 & 78 & & 1700 & 4800 & Gas at $230^{\circ} \mathrm{F}$ \\
\hline $\begin{array}{l}\text { Rotoclone } \\
\text { Type D }\end{array}$ & $\begin{array}{l}\text { Amertcan } \\
\text { Air Filter Co. }\end{array}$ & $\begin{array}{l}\text { Fluffy zinc } \\
\text { stearate from } \\
\text { rubber dusting } \\
\text { operation }\end{array}$ & 0.6 & 1.75 & & 88 & & & 3300 & \\
\hline $\begin{array}{l}\text { Rotoclone } \\
\text { Type D } \\
\text { (47) }\end{array}$ & $\begin{array}{l}\text { American } \\
\text { Air Filter Co. }\end{array}$ & $\begin{array}{l}\text { Fluffy zinc } \\
\text { stearate from } \\
\text { rubber dusting } \\
\text { operation }\end{array}$ & 1.7 & 1.75 & & 78 & & & 750 & \\
\hline $\begin{array}{l}\text { Cyclone } \\
(47)\end{array}$ & $\begin{array}{l}\text { Plant } \\
\text { Construction }\end{array}$ & $\begin{array}{l}\text { Talc dust from } \\
\text { abrasive cleaning } \\
\text { operation }\end{array}$ & 2.2 & 128 & & 93 & 0.33 & 1000 & 2300 & $7^{\prime}$ in diameter. \\
\hline $\begin{array}{l}\text { Cyclone } \\
(47)\end{array}$ & $\begin{array}{l}\text { Plant } \\
\text { Construction }\end{array}$ & $\begin{array}{l}\text { Wood dust from } \\
\text { planing mill } \\
\text { operations }\end{array}$ & 0.1 & $\begin{array}{c}99 \%>500 \\
\text { (weight) }\end{array}$ & & 97 & 3.7 & 3100 & 3500 & $6.5^{\prime}$ in diameter. \\
\hline $\begin{array}{l}\text { Cyclone } \\
\text { (47) }\end{array}$ & $\begin{array}{l}\text { Plant } \\
\text { Construction }\end{array}$ & $\begin{array}{l}\text { Aluminum dust } \\
\text { from grinding } \\
\text { operations }\end{array}$ & 0.7 & $\begin{array}{l}99 \%>500 \\
\text { (weight) }\end{array}$ & & 89 & 1.2 & 1400 & 4400 & $6^{\prime}$ in diameter. \\
\hline $\begin{array}{l}\text { Cyclone } \\
\text { (47) }\end{array}$ & $\begin{array}{l}\text { Plant } \\
\text { Construction }\end{array}$ & Cotton flock & 0.7 & $\begin{array}{c}99 \%>500 \\
\text { (weight) }\end{array}$ & & 88 & 1.6 & 2400 & 2600 & $6.5^{\prime}$ in diameter. \\
\hline
\end{tabular}




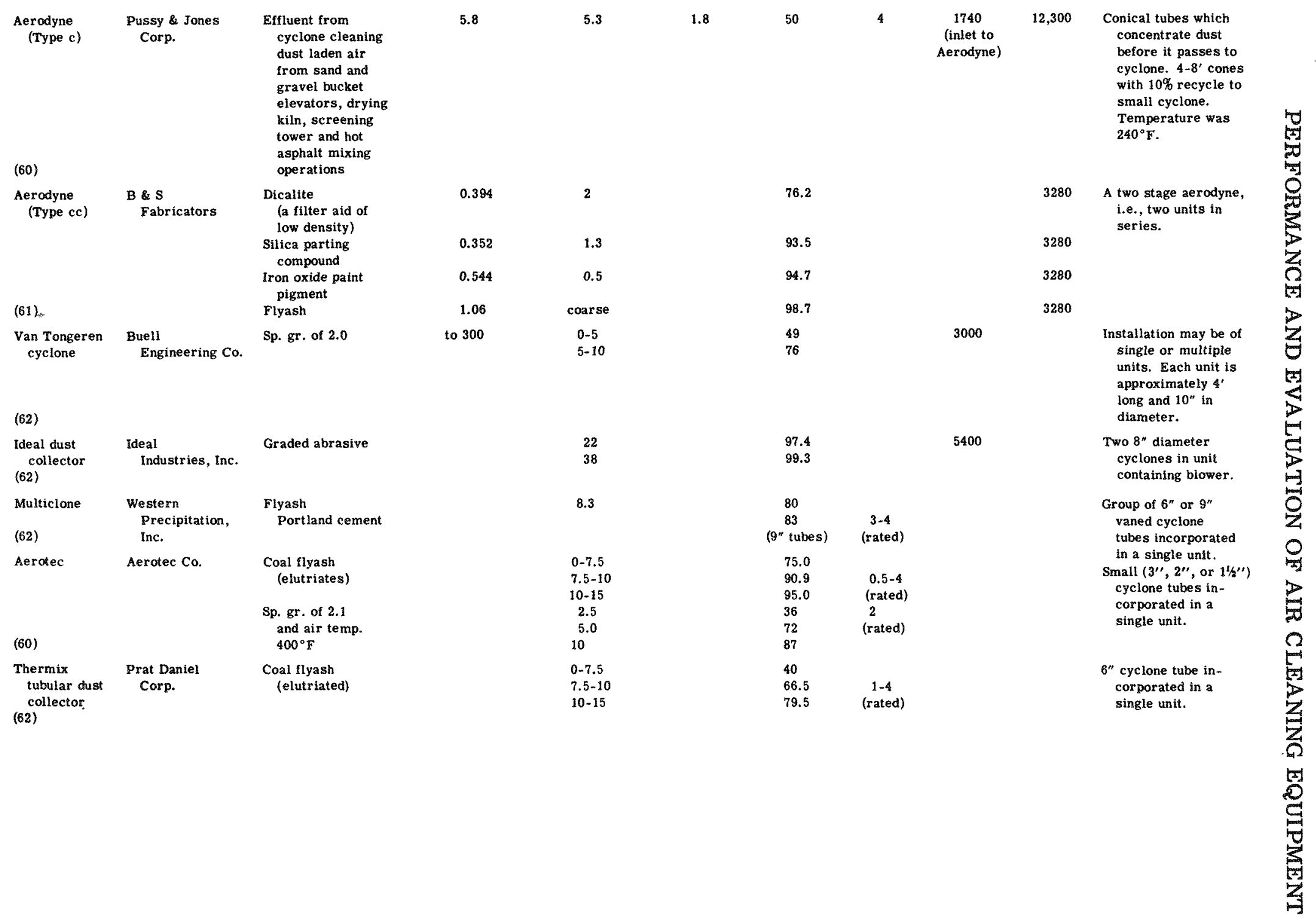


Table $3.4 \mathrm{~b}-$ Other Inertial Separators

Type $\mathrm{S}$

Hudson $\mathrm{H}$ Flyash

(62)

Eubar Co.

$85 \%<43$

80

0.06

Inlet
concentration
grains/CF
Eificiency
substantially
independent

article si

$$
\text { at inlet }
$$

Particle size

microns
mass medi

$>43$

s

Efficienc

weight $\%$

$\mathrm{H}_{2} \mathrm{O}$

$0.1-0.3$

independent

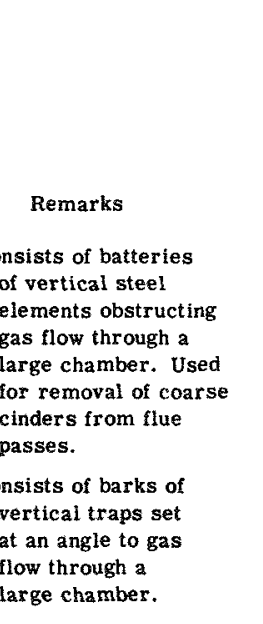

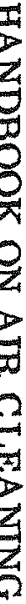


Table 3.5-Scrubbers and Other Wet Collectors

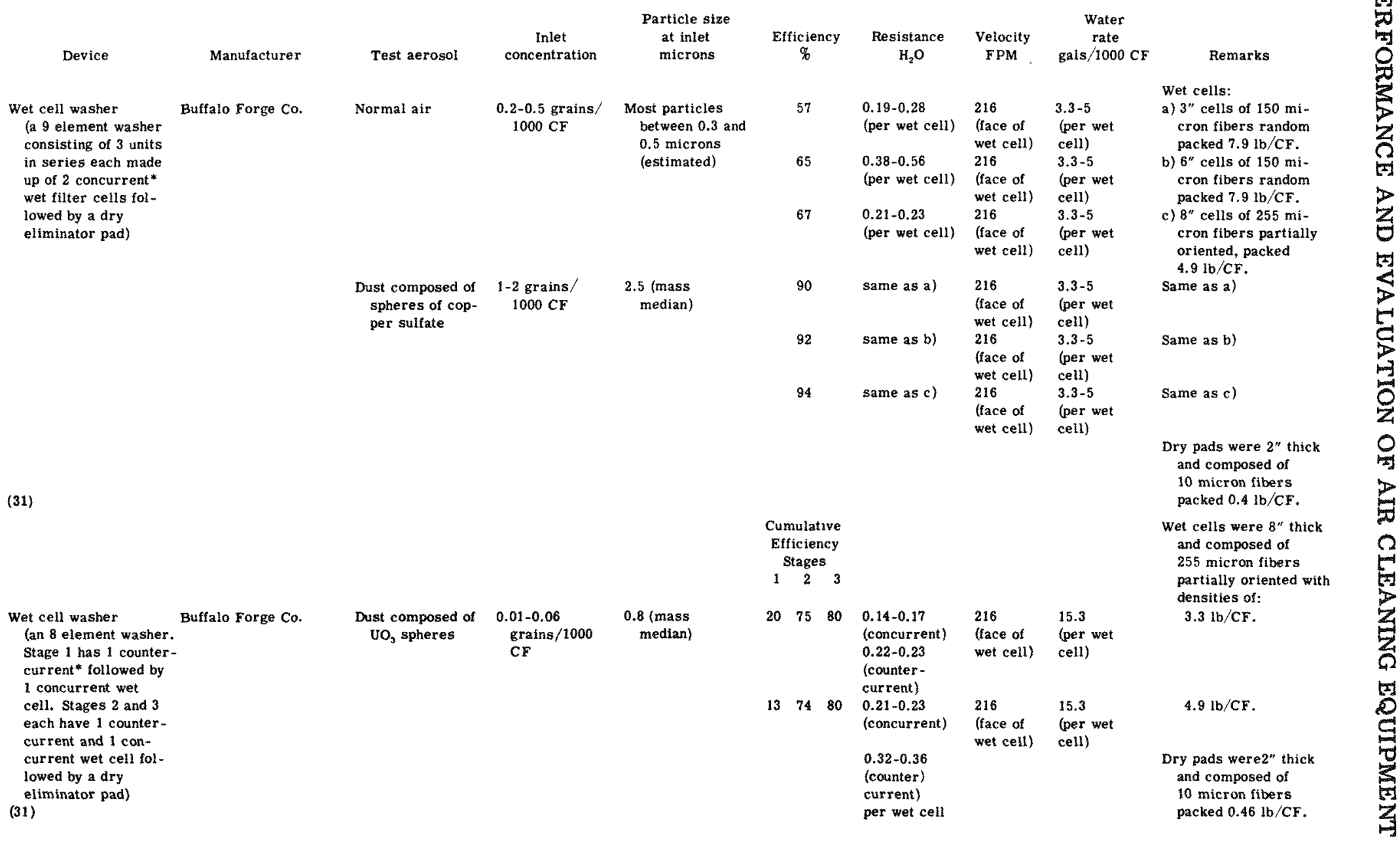




\begin{tabular}{|c|c|c|c|c|c|c|c|c|c|}
\hline Device & Manufacturer & Test aerosol & $\begin{array}{c}\text { Inlet } \\
\text { concentration }\end{array}$ & $\begin{array}{l}\text { Particle size } \\
\text { at inlet } \\
\text { microns }\end{array}$ & $\begin{array}{c}\text { Efficiency } \\
\%\end{array}$ & $\begin{array}{c}\text { Resistance } \\
\mathrm{H}_{2} \mathrm{O}\end{array}$ & $\begin{array}{l}\text { Velocity } \\
\text { FPM }\end{array}$ & $\begin{array}{c}\text { Water } \\
\text { rate } \\
\text { gals } / 1000 \text { CF }\end{array}$ & Remarks \\
\hline Ducon no. 5 & Ducon Co. & $\begin{array}{l}\text { Dust from stone } \\
\text { and sand drying } \\
\text { kilin }\end{array}$ & $5.8 \mathrm{grains} / \mathrm{CF}$ & 1.5 & $\begin{array}{c}74 \\
\text { (weight) }\end{array}$ & & & $\begin{array}{c}1 \\
\text { (rated) }\end{array}$ & $\begin{array}{l}\text { Flow rate was } 9300 \mathrm{CFM} \text {. } \\
\text { Temperature was } \\
230^{\circ} \mathrm{F} \text { in and } 120^{\circ} \mathrm{F} \\
\text { out. Aerosol was } \\
\text { effluent from } \\
\text { Sirocco No. } 20 \\
\text { cyclones. }\end{array}$ \\
\hline \multirow[t]{4}{*}{ Venturi scrubber } & $\begin{array}{l}\text { Pease Anthony Equip- } \\
\text { ment Co. }\end{array}$ & $\begin{array}{l}\mathrm{H}_{2} \mathrm{SO}_{4} \text { mist from } \\
\text { sulfuric acid }\end{array}$ & $2.92 \mathrm{grains} / \mathrm{CF}$ & & 99.7 & 9.7 & 10,260 & 4.3 & $\begin{array}{l}\text { Outlet concentration } \\
\text { was } 0.0092 \text { grains/CF. }\end{array}$ \\
\hline & & plant & $3.98 \mathrm{grains} / \mathrm{CF}$ & & 99.7 & 29.3 & 19,200 & 3.9 & $\begin{array}{l}\text { Outlet concentration } \\
\text { was } 0.011 \text { grains } / C F \text {. }\end{array}$ \\
\hline & & $\begin{array}{l}\mathrm{SiO}_{3} \text { from silicon } \\
\text { ore furnace }\end{array}$ & & $0.01-0.35$ & 86.7 & 11.0 & 15,060 & 4.7 & \\
\hline & & $\begin{array}{l}\text { Iron oxide fume } \\
\text { from open } \\
\text { hearth furnace } \\
\text { (oxygen lanced) }\end{array}$ & $\begin{array}{l}1-5.99 \\
\text { grains/CF }\end{array}$ & $0.02-0.5$ & $\begin{array}{l}\text { 92-99 } \\
\text { (weight) }\end{array}$ & 14.0 & 15,840 & & $\begin{array}{l}\text { Outlet concentration was } \\
0.0092-0.069 \text { grains/ } \\
\text { CF. }\end{array}$ \\
\hline Cyclone scrubber & $\begin{array}{l}\text { Pease Anthony Equip- } \\
\text { ment Co. }\end{array}$ & $\begin{array}{l}\text { Lime dust from } \\
\text { lime kiln. }\end{array}$ & $9.2 \mathrm{grains} / \mathrm{CF}$ & $2.0-40.0$ & 99 & $\begin{array}{l}2-4 \\
\text { (rated) }\end{array}$ & & $\begin{array}{c}5-10 \\
\text { (rated) }\end{array}$ & $\begin{array}{l}\text { Outlet concentration was } \\
0.08 \text { granns } / \mathrm{CF} \text {. }\end{array}$ \\
\hline (62) & & $\begin{array}{l}\text { Iron ore and coke } \\
\text { dust from blast } \\
\text { furnace }\end{array}$ & $\begin{array}{l}3.0-24.0 \\
\text { grains/CF }\end{array}$ & $0.5-20.0$ & $\begin{array}{c}99 \\
\text { (weight) }\end{array}$ & $\begin{array}{l}2-4 \\
\text { (rated) }\end{array}$ & & $\begin{array}{c}5-10 \\
\text { (rated) }\end{array}$ & $\begin{array}{l}\text { Outlet concentration was } \\
0.03-0.08 \text { grains } / \mathrm{CF} \text {. }\end{array}$ \\
\hline $\begin{array}{l}\text { Centri-merge } \\
(62)\end{array}$ & $\begin{array}{l}\text { Schmieg Industries, } \\
\text { Inc. }\end{array}$ & $\mathrm{Na}_{2} \mathrm{CO}_{3}$ fume & $\begin{array}{l}30 \times 10^{8} \\
\text { particles } / \mathrm{CF}\end{array}$ & & $\begin{array}{l}96.2 \\
\text { (count) }\end{array}$ & 5.5 & 2000 & 40 & \\
\hline $\begin{array}{l}\text { Multi-wash } \\
(62)\end{array}$ & $\begin{array}{l}\text { Claude B. Schneible } \\
\text { Co. }\end{array}$ & Foundry dust & $\begin{array}{l}99.7 \times 100 \\
\text { particles } / \mathrm{CF}\end{array}$ & $<15$ & $\begin{array}{l}88.9 \\
\text { (count) }\end{array}$ & 4 & 3300 & & Laboratory test. \\
\hline
\end{tabular}


Table 3.6a-Viscous Filters

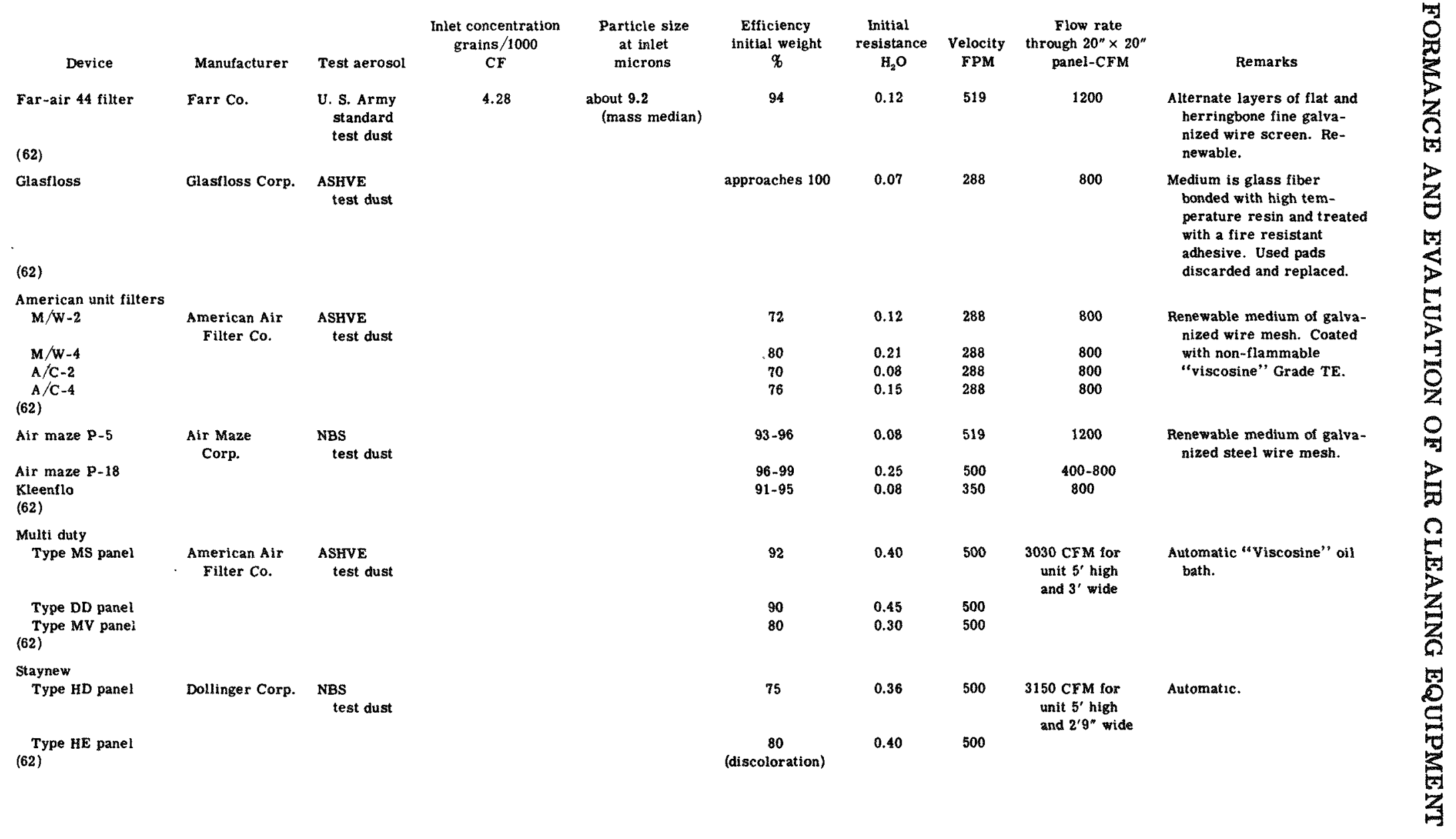


Table 3.6b-Dry Filters

\begin{tabular}{|c|c|c|c|c|c|c|c|c|}
\hline Device & Manufacturer & Test aerosol & $\begin{array}{c}\text { Inlet } \\
\text { concentration }\end{array}$ & $\begin{array}{l}\text { Particle size } \\
\text { at inlet } \\
\text { microns }\end{array}$ & $\begin{array}{c}\text { Efficiency } \\
\%\end{array}$ & $\begin{array}{c}\text { Resistance } \\
\mathrm{H}_{2} \mathrm{O}\end{array}$ & $\begin{array}{l}\text { Velocity } \\
\text { FPM }\end{array}$ & Remarks \\
\hline Dustop & $\begin{array}{l}\text { Owens-Corning } \\
\text { Fiberglas Corp. }\end{array}$ & City air & $\begin{array}{c}0.07 \text { grains } / \\
1000 \mathrm{CF}\end{array}$ & & $\begin{array}{l}56 \\
\text { (weight) }\end{array}$ & 0.025 & 150 & $\begin{array}{l}\text { A preliminary filter (coarse glass wool) } \\
\text { bark containing a double layer of Dust- } \\
\text { Stop filter units, } 4 \text { units high and } 5 \text { units } \\
\text { wide. Flow rate was } 8300 \text { CFM. }\end{array}$ \\
\hline $\begin{array}{l}\text { Dustop } \\
(60)\end{array}$ & $\begin{array}{l}\text { Owens-Corning } \\
\text { Fiberglas Corp. }\end{array}$ & $\begin{array}{l}35 \% \text { city air } \\
65 \% \text { recirculated } \\
\text { air }\end{array}$ & $\begin{array}{c}0.015 \text { grains } / \\
1000 \mathrm{CF}\end{array}$ & & $\begin{array}{l}42 \\
\text { (weight) }\end{array}$ & 0.17 & 167 & $\begin{array}{l}\text { A preliminary filter (coarse glass wool) for } \\
\text { city and recirculated air, containing a } \\
\text { double layer of filters, } 6 \text { units wide and } \\
6 \text { units high. Flow rate was } 24,000 \text { CFM. }\end{array}$ \\
\hline $\begin{array}{l}\text { Fiberglas } \\
\text { Type B } \\
\text { (36) }\end{array}$ & $\begin{array}{l}\text { Owens-Corning } \\
\text { Fiberglas Corp. }\end{array}$ & Normal air & $\begin{array}{l}793 \text { particles } / \mathrm{cc} \\
824 \text { particles } / \mathrm{cc}\end{array}$ & $\begin{array}{l}0.2-1.0 \text { with } \\
\text { most particles } \\
\text { between } 0.3 \\
\text { and } 0.5\end{array}$ & $\begin{array}{l}62.9 \\
62.4 \\
\text { (count) }\end{array}$ & $\begin{array}{l}0.05 \\
0.12\end{array}$ & $\begin{array}{l}33 \\
31\end{array}$ & $\begin{array}{l}\text { One } 1 / 2^{\prime \prime} \text { sheets. Fiber diameter } 1.3 \text { microns, } \\
\text { density } 0.5 \mathrm{lb} / \mathrm{CF} \text {. } \\
\text { Two } 1 / z^{\prime \prime} \text { sheets. }\end{array}$ \\
\hline $\begin{array}{l}\text { Fiberglas } \\
\text { Typé AA } \\
\text { (36) }\end{array}$ & $\begin{array}{l}\text { Owens-Corning } \\
\text { Fiberglas Corp. }\end{array}$ & Normal air & $\begin{array}{l}540 \text { particles/cc } \\
1796 \text { particles/cc }\end{array}$ & $\begin{array}{l}0.2-1.0 \text { with } \\
\text { most particles } \\
\text { between } 0.3 \\
\text { and } 0.5\end{array}$ & $\begin{array}{l}91.3 \\
99.36 \\
\text { (count) }\end{array}$ & $\begin{array}{l}0.61 \\
1.48\end{array}$ & $\begin{array}{l}28.5 \\
26.9\end{array}$ & $\begin{array}{l}\text { One } 1 / z^{\prime \prime} \text { sheet. Fiber diameter } 3 \text { microns. } \\
\text { Density } 0.6 \mathrm{lb} / \mathrm{CF} \text {. } \\
\text { Two } 1 / \mathrm{z}^{\prime \prime} \text { sheets. }\end{array}$ \\
\hline $\begin{array}{l}1 \text { sheet } B \\
1 \text { sheet } A A \\
\text { (36) }\end{array}$ & $\begin{array}{l}\text { Owens-Corning } \\
\text { Fiberglas Corp. }\end{array}$ & Normal air & $4248 \mathrm{particles} / \mathrm{cc}$ & $\begin{array}{l}0.2-1.0 \text { with } \\
\text { most particles } \\
\text { between } 0.3 \\
\text { and } 0.5\end{array}$ & $\begin{array}{l}93.9 \\
\text { (count) }\end{array}$ & 0.91 & 30 & Each sheet $1 / 2^{\prime \prime}$. \\
\hline Glastex GB & Dollinger Corp. & Normal air & $\begin{array}{l}681 \text { particles } / \mathrm{cc} \\
825 \text { particles } / \mathrm{cc}\end{array}$ & $\begin{array}{l}0.2-1.0 \text { with } \\
\text { most particles } \\
\text { between } 0.3 \\
\text { and } 0.5\end{array}$ & $\begin{array}{l}47.5 \\
16.2 \\
\text { (count) }\end{array}$ & $\begin{array}{l}0.06 \\
0.50\end{array}$ & $\begin{array}{c}5.25 \\
26.7\end{array}$ & A glass fabric. \\
\hline Glastex $6 \mathrm{~A}$ & Dollinger Corp. & Normal air & $\begin{array}{l}645 \text { particles/cc } \\
624 \text { particles } / \mathrm{cc}\end{array}$ & $\begin{array}{l}0.2-1.0 \text { with } \\
\text { most particles } \\
\text { between } 0.3 \\
\text { and } 0.5\end{array}$ & $\begin{array}{l}22.4 \\
13.1 \\
\text { (cuunt) }\end{array}$ & $\begin{array}{l}0.02 \\
0.25\end{array}$ & $\begin{array}{c}5.25 \\
34.2\end{array}$ & A glass fabric. \\
\hline
\end{tabular}




\begin{tabular}{|c|c|c|c|c|c|c|c|c|}
\hline Airmat & $\begin{array}{l}\text { American Air } \\
\text { Filter Co. }\end{array}$ & $\begin{array}{l}\text { Fluffy zinc } \\
\text { stearate from } \\
\text { rubber dusting } \\
\text { operation }\end{array}$ & 0.1 grains/CF & $\begin{array}{c}1.75 \\
\text { (mass median) }\end{array}$ & $\begin{array}{l}95 \\
\text { (weight) }\end{array}$ & & & $\begin{array}{l}\text { Pocketed filter cleaned by vibrating at } \\
\text { intervals. Paper medium. Flow rate was } \\
3300 \text { CFM. }\end{array}$ \\
\hline Airmat & $\begin{array}{l}\text { American Air } \\
\text { Filter Co. }\end{array}$ & $\begin{array}{l}\text { Fluffy zinc } \\
\text { stearate from } \\
\text { rubber dusting } \\
\text { operation }\end{array}$ & 0.3 grains $/ C F$ & $\begin{array}{c}1.75 \\
\text { (mass median) }\end{array}$ & $\begin{array}{l}33 \\
\text { (weight) }\end{array}$ & & & $\begin{array}{l}\text { Same as above. Paper was torn after wetting } \\
\text { by condensed moisture. Flow rate was } \\
750 \mathrm{CFM} \text {. }\end{array}$ \\
\hline Alrmat & $\begin{array}{l}\text { American Air } \\
\text { Filter Co. }\end{array}$ & $\begin{array}{l}\text { Fluffy zinc } \\
\text { stearate from } \\
\text { rubber dusting } \\
\text { operation }\end{array}$ & $0.6-1.0 \mathrm{grains} / \mathrm{CF}$ & $\begin{array}{c}1.75 \\
\text { (mass median) }\end{array}$ & $\begin{array}{c}\text { nearly } 100 \\
\text { (weight) }\end{array}$ & & & $\begin{array}{l}\text { Same. Cotton cloth medium. Flow rate was } \\
400 \mathrm{CFM} \text {. }\end{array}$ \\
\hline $\begin{array}{l}\text { Filter } \\
\text { Type FU } \\
\text { (62) }\end{array}$ & $\begin{array}{l}\text { Coppus Engineer- } \\
\text { ing Corp. }\end{array}$ & $\begin{array}{l}\text { NBS test cust } \\
\text { Silica dust }\end{array}$ & & $\begin{aligned} 97 \% & <1 \\
& <2\end{aligned}$ & $\begin{array}{l}85 \\
\text { (discoloration) } \\
95.6 \\
\text { (count) }\end{array}$ & $\begin{array}{l}0.26 \\
\text { (initial) }\end{array}$ & 50 & $\begin{array}{l}\text { A wool felt filter "glove" which fits over a } \\
\text { retainer grid. Filter can be cleaned without } \\
\text { dissembling by means of a portable vacuum } \\
\text { cleaner. }\end{array}$ \\
\hline $\begin{array}{l}\text { Airmat } \\
\text { Type PL-24 } \\
6 \text { ply paper } \\
\text { 10 piy paper } \\
\text { Type G Airmat } \\
\text { Type G Airmat } \\
\text { (62) }\end{array}$ & $\begin{array}{l}\text { American Air } \\
\text { Filter Co. }\end{array}$ & $\begin{array}{l}\text { ASHVE } \\
\text { test dust }\end{array}$ & & & $\begin{array}{l}94 \\
96 \\
90 \\
92 \\
\text { (weight) }\end{array}$ & $\begin{array}{c}0.075 \\
0.075 \\
0.028 \\
0.028 \\
\text { (initial) }\end{array}$ & $\begin{array}{l}35 \\
28 \\
35 \\
35\end{array}$ & $\begin{array}{l}\text { A pleated filter. } \\
\text { Available fireproofed. Discarded after use. } \\
1 /{ }^{\prime \prime} \text { bonded fiberglass. } \\
\text { 'zz:" bonded fiberglass. } \\
\text { Discarded after use. }\end{array}$ \\
\hline $\begin{array}{l}\text { Wool felt } \\
\quad \# 1580 \\
\# 7544 \\
\# 1405 \\
(62)\end{array}$ & $\begin{array}{l}\text { American Felt } \\
\text { Co. }\end{array}$ & Mineral dust & & $\begin{array}{c}0.7 \\
\text { (mean diameter) }\end{array}$ & $\begin{array}{l}98 \\
99 \\
100 \\
\text { (weight) }\end{array}$ & $\begin{array}{l}0.5 \\
0.5 \\
0.5\end{array}$ & $\begin{array}{r}28 \\
13 \\
2\end{array}$ & $\begin{array}{l}14.0-15.3 \mathrm{oz} / \mathrm{sq} \mathrm{yd}, 1 / 1 \mathrm{~s}^{\prime \prime} \text { thick, } 0.79 \text { porosity. } \\
16.2-17.4 \mathrm{oz} / \mathrm{sq} \mathrm{yd}, 1 / \mathrm{ss}^{\prime \prime} \text { thick, } 0.79 \text { porosity. } \\
22.3-24.0 \mathrm{oz} / \mathrm{sq} \mathrm{yd}, 1 / \mathrm{ss}^{\prime \prime} \text { thick, } 0.62 \text { porosity. }\end{array}$ \\
\hline
\end{tabular}


Table 3.6c-Cloth Filters

\begin{tabular}{|c|c|c|c|c|c|c|c|c|c|c|c|c|}
\hline Device & Manufacturer & Test aerosol & $\begin{array}{l}\text { Inlet con- } \\
\text { centration } \\
\text { grains/CF }\end{array}$ & $\begin{array}{l}\text { Particle size } \\
\text { at inlet } \\
\text { microns } \\
\text { (mass median) }\end{array}$ & $\begin{array}{c}\text { Effluent } \\
\text { concentration } \\
\text { grains } / C F\end{array}$ & $\begin{array}{c}\text { Particle size } \\
\text { at exit } \\
\text { microns } \\
\text { (mass median) }\end{array}$ & $\begin{array}{c}\text { Efficiency } \\
\text { weight } \\
\%\end{array}$ & $\begin{array}{c}\text { Penetration } \\
\text { weight } \\
\%\end{array}$ & $\begin{array}{c}\text { Resistance } \\
\mathrm{H}_{2} \mathrm{O}\end{array}$ & $\begin{array}{l}\text { Velocity } \\
\text { FPM or } \\
\text { CFM/sq ft }\end{array}$ & $\begin{array}{c}\text { Flow rate } \\
\text { CFM }\end{array}$ & Remarks \\
\hline Aeroturn & $\begin{array}{l}\text { Turner \& } \\
\text { Haws } \\
\text { Eng. Co. }\end{array}$ & $\begin{array}{l}\text { Silicon carbide and } \\
\text { aluminum oxide } \\
\text { custs from truing } \\
\text { and shaping of } \\
\text { abrasive products }\end{array}$ & 0.13 & 1.40 & 0.001 & 0.55 & 99.2 & 0.8 & 4 & 17.0 & 18,800 & $\begin{array}{l}\text { A Hersey type bag filter. } \\
12 \text { bags } 1.5^{\prime} \text { diam., } \\
20^{\prime} \text { long. } y^{\prime \prime} \text { pressed } \\
\text { wool felt cloth. }\end{array}$ \\
\hline Aeroturn a) & $\begin{array}{l}\text { Turner \& } \\
\text { Haws } \\
\text { Eng. Co. }\end{array}$ & $\begin{array}{l}\text { Silicon carbide and } \\
\text { aluminum oxide } \\
\text { dusts from truing } \\
\text { and shaping of }\end{array}$ & 2.26 & 2.50 & 0.0009 & 1.25 & 99.9 & 0.04 & 1.35 & 5.5 & 930 & $\begin{array}{l}\text { Aeroturn with interior } \\
\text { partition acting as } \\
\text { two independent units } \\
\text { of equal capacity. }\end{array}$ \\
\hline$(60)$ & & abrasive products & 0.66 & 1.30 & 0.0008 & 0.53 & 99.8 & 0.121 & & 7.2 & 1,230 & $\begin{array}{l}4 \text { bags, } 1.5^{\prime} \text { diam., } \\
9^{\prime} \text { long. } 1 / \mathrm{g}^{\prime \prime} \text { pressed } \\
\text { wool felt cloth. }\end{array}$ \\
\hline $\begin{array}{l}\text { Aeroturn } \\
(60)\end{array}$ & $\begin{array}{l}\text { Turner \& } \\
\text { Haws } \\
\text { Eng. Co. }\end{array}$ & Beryllium oxide dust & st 0.0037 & & .00000425 & & 99.88 & 0.115 & 2.8 & 12.7 & 7,200 & 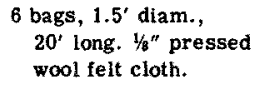 \\
\hline Aeroturn & $\begin{array}{l}\text { Turner \& } \\
\text { Haws } \\
\text { Eng. Co. }\end{array}$ & $\begin{array}{l}\text { Jewelers rouge (iron } \\
\text { oxide) and lint } \\
\text { from buffing and } \\
\text { polishing watch } \\
\text { cases }\end{array}$ & 0.0048 & 0.90 & 0.00012 & 0.57 & 97.5 & 2.5 & 3.6 & 27 & 5,000 & $\begin{array}{l}4 \text { bags, } 1.5^{\prime} \text { diam., } \\
12^{\prime} \text { long. } 1 / \text { la pressed }^{\prime \prime} \text {, } \\
\text { wool felt cloth. }\end{array}$ \\
\hline Aeroturn & $\begin{array}{l}\text { Turner } \\
\text { Haws } \\
\text { Eng. Co. }\end{array}$ & $\begin{array}{l}\text { Jewelers rouge (iron } \\
\text { oxide) and lint } \\
\text { from buffing and } \\
\text { polishing watch } \\
\text { cases }\end{array}$ & 0.0094 & 1.21 & 0.0022 & 0.74 & 97.6 & 2.4 & 6.4 & 32 & 6,000 & $\begin{array}{l}4 \text { bags, } 1.5^{\prime} \text { diam., } \\
12^{\prime} \text { long. } 4 \text { ta }^{\prime \prime} \text { pressed } \\
\text { wool felt cloth. }\end{array}$ \\
\hline
\end{tabular}




\begin{tabular}{|c|c|c|c|c|c|c|c|c|c|c|c|c|}
\hline $\begin{array}{l}\text { Aeroturn } \\
(60)\end{array}$ & $\begin{array}{l}\text { Turner \& } \\
\text { Haws } \\
\text { Eng. Co. }\end{array}$ & $\begin{array}{l}\text { Tapioca starch } \\
\text { granules from } \\
\text { drying ovens }\end{array}$ & 3.17 & 7.7 & 0.000054 & 1.1 & 99.99 & 0.0015 & 4.4 & 11.3 & 2,100 & $\begin{array}{l}4 \text { bags, } 1.5^{\prime} \text { diam., } \\
11^{\prime} \text { long. } 4 \text { c }^{\prime \prime} \text { pressed } \\
\text { woll felt cloth. }\end{array}$ \\
\hline$(60)$ & $\begin{array}{l}\text { American } \\
\text { Wheelabra- } \\
\text { tor and } \\
\text { Equip. } \\
\text { Corp. }\end{array}$ & $\begin{array}{l}\text { Bronze and } \mathrm{SiO}_{2} \\
\text { dusts from cast- } \\
\text { ing cleaning } \\
\text { operations }\end{array}$ & 0.441 & 4.5 & .000069 & 1.7 & 99.98 & 0.0156 & 5.0 & 0.8 & 565 & $\begin{array}{l}94 \text { bags, } 5^{\prime \prime} \text { diam., } \\
70^{\prime \prime} \text { long, } 720 \mathrm{sq} \mathrm{ft} \\
\text { cloth area, cotton } \\
\text { cloth. }\end{array}$ \\
\hline (60) & $\begin{array}{l}\text { American } \\
\text { Wheelabra- } \\
\text { tor and } \\
\text { Equip. } \\
\text { Corp. }\end{array}$ & $\begin{array}{l}\text { Iron oxide and } \\
\mathrm{SiO}_{2} \text { dusts from } \\
\text { casting cleaning } \\
\text { operations }\end{array}$ & 0.68 & 1.52 & 0.000015 & $\begin{array}{c}0.2-0.3 \\
\text { (estimated) }\end{array}$ & 99.99 & 0.0022 & 1.5 & 2.5 & 7,700 & $\begin{array}{l}288 \text { bags, } 12^{\prime} \text { long, } \\
2820 \text { sq ft cloth area, } \\
\text { cotton cloth. }\end{array}$ \\
\hline Dustube & $\begin{array}{l}\text { American } \\
\text { Wheelabra- } \\
\text { tor and } \\
\text { Equip. } \\
\text { Corp. }\end{array}$ & $\begin{array}{l}\text { Iron scale and } \\
\text { sand from } \\
\text { casting clean- } \\
\text { ing operations }\end{array}$ & 0.33 & 3.45 & 0.000013 & & 99.99 & .0039 & 2.2 & 2.2 & 2,050 & $\begin{array}{l}96 \text { bags, } 4 \text { ' long, } 940 \text { sq } \\
\text { ft cloth area, cotton } \\
\text { cloth. }\end{array}$ \\
\hline $\begin{array}{l}\text { Pangborn } \\
\text { (47) }\end{array}$ & $\begin{array}{l}\text { Pangborn } \\
\text { Corp. }\end{array}$ & $\begin{array}{l}\text { Talc dust from } \\
\text { rubber dusting }\end{array}$ & 4.3 & 113 & .002 & & 99.85 & & & & 7,000 & \\
\hline $\begin{array}{l}\text { Sly } \\
\text { collector } \\
(60)\end{array}$ & $\begin{array}{l}\text { Sly Mfg. } \\
\text { Co. }\end{array}$ & $\begin{array}{l}\text { Granite dust from } \\
\text { chipping }\end{array}$ & 0.032 & 2.3 & 0.000028 & 1.1 & 99.9 & 0.088 & about 3.0 & 2.3 & 7,000 & $\begin{array}{l}3000 \text { sq it cloth area, } \\
\text { cotton cloth. }\end{array}$ \\
\hline $\begin{array}{l}\text { Sly } \\
\text { collector } \\
(60)\end{array}$ & $\begin{array}{l}\text { Sly Mig. } \\
\text { Co. }\end{array}$ & $\begin{array}{l}\text { Iron scale and } \\
\text { sand from } \\
\text { castings } \\
\text { cleanings }\end{array}$ & 0.18 & 1.44 & 0.000013 & & 99.99 & .0072 & 1.2 & 1.3 & 13,900 & $\begin{array}{l}510 \text { frames, } 11,220 \mathrm{sq} \\
\text { ft cloth area, cotton } \\
\text { cloth. }\end{array}$ \\
\hline $\begin{array}{l}\text { Sly } \\
\text { collector } \\
(60)\end{array}$ & $\begin{array}{l}\text { Siy Mfg. } \\
\text { Co. }\end{array}$ & $\begin{array}{l}\text { Iron scale and } \\
\text { sand from } \\
\text { castings } \\
\text { cleanings }\end{array}$ & 0.39 & 2.2 & 0.00063 & 0.64 & 99.85 & 0.16 & 1.9 & 1.5 & 18,200 & $\begin{array}{l}12,320 \mathrm{sq} \text { ft cloth } \\
\text { area, cotton cloth. }\end{array}$ \\
\hline
\end{tabular}


Table 3.6d-High Efficiency Filters

\begin{tabular}{|c|c|c|c|c|}
\hline Device & Manufacturer & Test aerosol & $\begin{array}{c}\text { Inlet } \\
\text { Concentration } \\
\text { particles } / \mathrm{cc}\end{array}$ & $\begin{array}{l}\text { Particle } \\
\text { at inl } \\
\text { micro }\end{array}$ \\
\hline $\begin{array}{l}\mathrm{CC}-6 \text { cel- } \\
\text { lulose-asbestos } \\
\text { paper } \\
(39)\end{array}$ & $\begin{array}{l}\text { Hollingsworth } \\
\text { and Vose Co. }\end{array}$ & $\begin{array}{l}\text { Methylene } \\
\text { blue }\end{array}$ & $\begin{array}{l}\text { about } 10 \\
\text { grains } / 1000 \\
\text { CF }\end{array}$ & $\begin{array}{l}\text { about } 0.7 \\
\text { (mass m }\end{array}$ \\
\hline $\begin{array}{l}\text { AEC cellulose- } \\
\text { asbestos paper }\end{array}$ & $\begin{array}{l}\text { Hollingsworth } \\
\text { and Vose Co. }\end{array}$ & $\begin{array}{l}\text { Normal air } \\
\text { After } 205 \\
\text { minutes of } \\
\text { running }\end{array}$ & $\begin{array}{l}2003 \\
1133\end{array}$ & $\begin{array}{l}0.2-1.0 \text { wit } \\
\text { most par } \\
\text { between } \\
0.5\end{array}$ \\
\hline $\begin{array}{c}\text { Compressed } \\
\text { glass fiber }\end{array}$ & $\begin{array}{l}\text { Owens-Corning } \\
\text { Fiberglas } \\
\text { Corp. }\end{array}$ & Normal aur & $\begin{array}{l}3870 \\
4820\end{array}$ & $\begin{array}{l}0.2-1.0 \text { wit } \\
\text { most par } \\
\text { between } \\
0.5\end{array}$ \\
\hline (36) & & & & \\
\hline $\begin{array}{l}\text { Glass fiber } \\
\text { paper }\end{array}$ & & & & \\
\hline AAA Superfine & & $\begin{array}{l}\text { Dioctyl } \\
\text { phthalate }\end{array}$ & $\begin{array}{l}\text { about } 40 \\
\text { grains } / 1000 \\
\text { CF }\end{array}$ & about 0.3 \\
\hline AA Superfine & & $\begin{array}{l}\text { Dioctyl } \\
\text { phthalate }\end{array}$ & $\begin{array}{l}\text { about } 40 \\
\text { grains } / 1000 \\
\text { CF }\end{array}$ & about 0.3 \\
\hline
\end{tabular}

(65)

\section{article size}

at inlet

Efficiency
qby count

Penetratio

\% by count

99.9871

0.0129

(discoloration)

0.7

$2-1.0$ with

most particles

0.5

99.980

99.993

0.0197

0.0065

0.00027

most particles

most particles

99.85

0.141

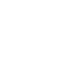

0.003
0.000
0.000
0.005
0.002
0.000

3.85

3.9

(penetrometer)

\section{Resistance Velocity \\ FPM}

4

5.25 Composed of specially treated Kraft fiber, cotton fiber, Bolivian asbestos, and, sometimes, a small amount of hemp fiber. As 1 micron.

$5.2550 \%$ of the fibers were 1.3 microns and $50 \% 3$ microns. Mat thickness was
$0.041^{\prime \prime}$. Mat density was $24 \mathrm{lb} / \mathrm{CF}$. $33 \%$ of the ftbers were 1.3 microns and $67 \% 3$ microns. Mat thickness was $0.055^{\prime \prime}$. Mat density was $15 \mathrm{lb} / \mathrm{CF}$.

Fibers were less than 0.75 microns in diameter. Paper was $0.01^{\text {" thick }}$ with tensile strength of $22 \mathrm{psi}$ and moisture content of $0.1 \%$. Fibers were between 0.75 and $1.50 \mathrm{microns}$ in diameter. Paper was $0.018^{\prime \prime}$ thick with tensile strength of $18 \mathrm{psi}$ and moisture content of $0.1 \%$. 
70

Table $3.7 \mathrm{~b}-$ Two Stage Electric Precipitators

\begin{tabular}{|c|c|c|c|c|c|c|c|}
\hline Device & Manufacturer & Test aerosol & $\begin{array}{c}\text { Inlet } \\
\text { concentration } \\
\text { grains } / 1000 \mathrm{CF}\end{array}$ & $\begin{array}{l}\text { Particle size } \\
\text { at inlet } \\
\text { microns }\end{array}$ & $\begin{array}{c}\text { Efficiency } \\
\text { discoloration } \\
\%\end{array}$ & $\begin{array}{l}\text { Ionizing } \\
\text { voltage }\end{array}$ & $\begin{array}{r}\text { Collectir } \\
\text { voltage }\end{array}$ \\
\hline $\begin{array}{l}\text { Precipitron } \\
(60)\end{array}$ & $\begin{array}{l}\text { Westinghouse } \\
\text { Electric } \\
\text { Côrp. }\end{array}$ & $\begin{array}{c}\text { City air passed } \\
\text { through glass } \\
\text { wool filter }\end{array}$ & 0.031 & $<0.2-0.3$ & $\begin{array}{l}89 \\
\text { (weight) }\end{array}$ & 13,000 & 6,000 \\
\hline $\begin{array}{l}\text { Precipitron } \\
\text { Model PH-12 }\end{array}$ & $\begin{array}{l}\text { Westinghouse } \\
\text { Electric } \\
\text { Corp. }\end{array}$ & $\begin{array}{l}\text { Dioctyl } \\
\text { phthalate }\end{array}$ & about 40 & about 0.3 & $\begin{array}{l}99.996+ \\
90 \\
45 \\
\text { (penetrometer) }\end{array}$ & & \\
\hline \multicolumn{8}{|l|}{ (69) } \\
\hline Trion & Trion, Inc. & $\begin{array}{c}\text { Cell ventila- } \\
\text { tion gases } \\
\text { (acid mist) }\end{array}$ & & & $\begin{array}{l}94 \\
\quad 82 \\
\text { (radioactivity) }\end{array}$ & & \\
\hline \multicolumn{8}{|l|}{ (70) } \\
\hline Electromaze & $\begin{array}{l}\text { Air Maze } \\
\text { Corp. }\end{array}$ & NBS test dust & & & 90 & 10,000 & 10,000 \\
\hline \multicolumn{8}{|l|}{ (62) } \\
\hline $\begin{array}{l}\text { Precipitator } \\
\text { (62) }\end{array}$ & $\begin{array}{l}\text { Raytheon } \\
\text { Mfg. Co. }\end{array}$ & Normal air & & & 90 & 12,000 & 6,000 \\
\hline $\begin{array}{l}\text { Electro- } \\
\text { cell }\end{array}$ & $\begin{array}{l}\text { American } \\
\text { Air Filter } \\
\text { Co. }\end{array}$ & $\begin{array}{l}\text { Atmospheric } \\
\text { dust cont'g } \\
50 \% \text { carbon } \\
\text { smoke, } 35 \% \\
\text { siliceous } \\
\text { matter, } 5 \% \\
\text { coal dust, } \\
3 \% \text { fibrous } \\
\text { matter, } 7 \% \\
\text { miscellaneous }\end{array}$ & . & $1 / 4-50$ & 90 & 12,000 & \\
\hline
\end{tabular}

Power

consumption Resistance Velocity Flow rate

$\begin{array}{cccc}\begin{array}{c}\text { Resistance } \\ \mathrm{H}_{2} \mathrm{O}\end{array} & \begin{array}{c}\text { Velocity } \\ \text { FPM }\end{array} & \begin{array}{c}\text { Flow rate } \\ \text { CFM }\end{array} & \text { Remarks } \\ 0.02 & 154 & 8300 & \begin{array}{c}\text { Face dimensions of } \\ \text { unit were } 6^{\prime} \times 9^{\prime}\end{array}\end{array}$

unit were $6^{\prime} \times 9^{\prime}$.

Units mounted in

special aluminum

housings designed to

prevent the air from

by -passing either

the tonizing stage

collector plates.

0.069

1.064

600

ell ventilation gases

have concentration

on the order of

$5 \times 10^{-3} \mathrm{mc} / \mathrm{CF}$

Precipitator was

used as precleane

before filter.

$300 \quad 300$ for

$12 " \times 12 " \times$

$12 " \times 12$
$261^{\prime \prime}$
panel

$300 \quad 1800$ for

cells

0.18

300

950 for

unit

high and

2 ' wide 


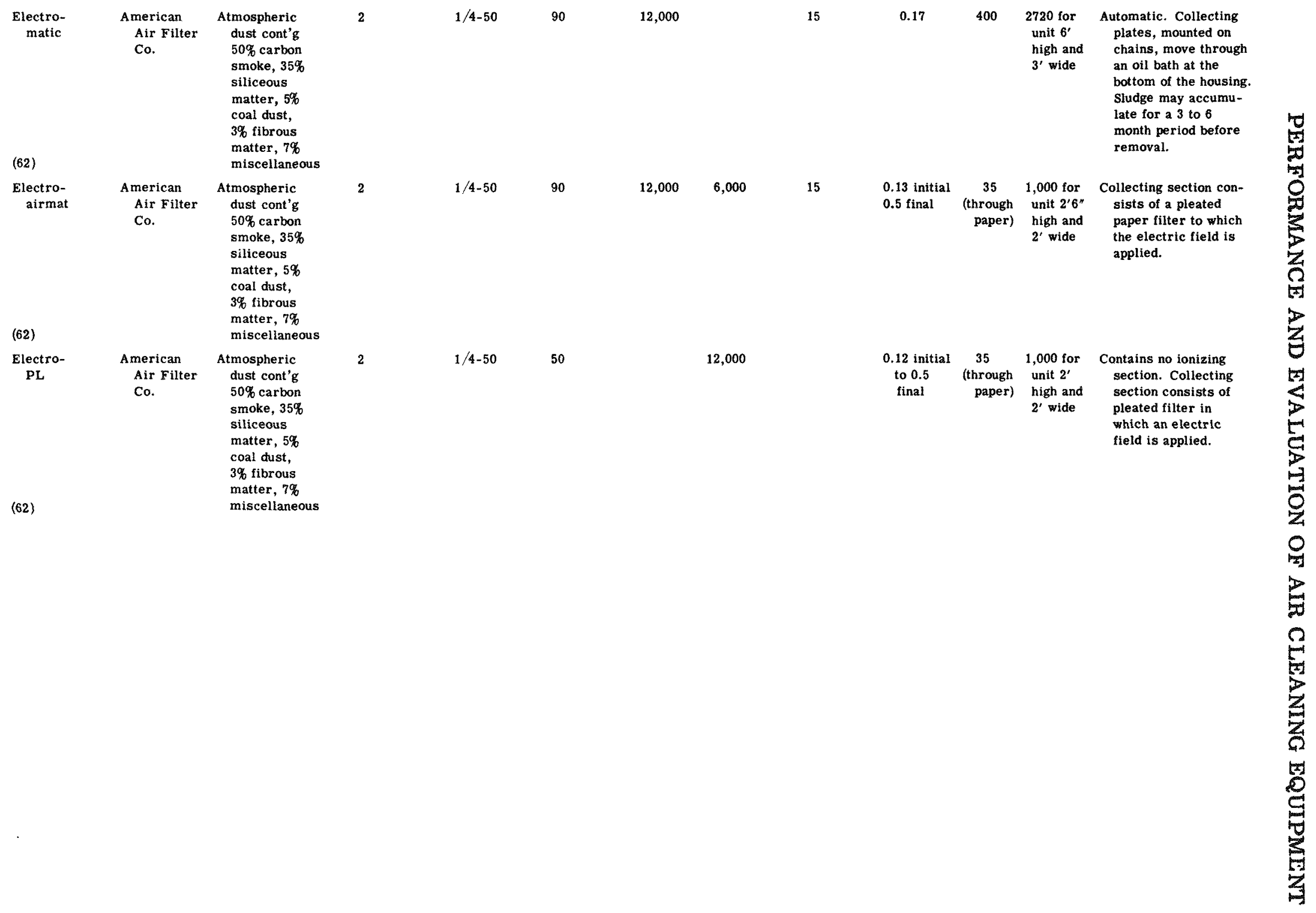


ing equation assuming a fan-motor efficiency of $63 \%$ :

$$
\mathrm{HP}=\frac{\mathrm{Q} \Delta \mathrm{P}}{4000}
$$

where $Q=$ flow rate (CFM)

$\Delta \mathbf{P}=$ pressure drop-inches of water

Maintenance costs commonly are negligible. Exceptions are the removal of abrasive particulates, e.g., carborundum or alundum, or the cleaning of corrosive gases.

\section{Wet Collectors}

1. Wet Filters. Initial costs for wet filters range around $\$ .09$ or $\$ .10 / C F M$. About two hours per week of maintenance are required for washing and cleaning the units. The wet cells rarely must be replaced in less than a year, and the average period of service is two years.

2. Centrifugal or Inertial Scrubbers. Cyclone scrubbers are not sold as standard units but are especially designed for each cleaning job. Table 3.8 gives approximate initial costs for these cleaners. Power requirements usually range from 1 to $3 \mathrm{HP} / 1000 \mathrm{CFM}$.

Initial costs for the Type $\mathrm{W}$ Rotoclone vary from about $\$ .15$ to $\$ .18 / \mathrm{CFM}$ in the 10 to 40,000 CFM range, while Type $\mathrm{N}$ costs vary from about $\$ .20$ to $\$ .25 / \mathrm{C}$ FM in the same capacity range. These prices do not include accessory equipment like motors and drives. The price of the Type $N$ Rotoclone does include the exhaust fan. Power costs can be calculated from Eq. 3.2.

3. Venturi Scrubber. Venturi scrubbers, like the cyclone scrubber, are es- pecially designed for each cleaning job. Approximate initial costs are given in Table 3.9. Power requirements range from about 3 to $5 \mathrm{HP} / 1000 \mathrm{CFM}$.

Table 3.8-Initial Costs for Cyclone Scrubbers

$\begin{array}{rcc}\begin{array}{c}\text { Capacity } \\ \text { CFM }\end{array} & \begin{array}{c}\text { Mild steel } \\ \$ / \text { CFM }\end{array} & \begin{array}{c}\text { Stainless steel } \\ \$ / C F M\end{array} \\ 500 & 1.50 & 2.25 \\ 1,000 & 1.25 & 1.50 \\ 10,000 & 0.50 & 1.00 \\ \text { over } 25,000 & 0.40 & 0.80\end{array}$

Table 3.9-Initial Costs for Venturi Scrubbers (Includes Exit Cyclone)

$\begin{array}{rcc}\begin{array}{c}\text { Capacity } \\ \text { CFM }\end{array} & \begin{array}{c}\text { Mild steel } \\ \text { \$/CFM }\end{array} & \begin{array}{c}\text { Stainless steel } \\ \text { \$/CFM }\end{array} \\ 500 & 2.00 & 3.00 \\ 1,000 & 1.50 & 2.00 \\ 10,000 & 0.75 & 1.50 \\ \text { over } 25,000 & 0.50 & 1.00\end{array}$

\section{Filters}

1. Air Conditioning Filters. Initial and operating costs for various viscous and dry filters are given in Table 3.10 adapted from Carrier, Cherne, and Grant. ${ }^{34}$

2. Cloth Filters. (a) Initial Costs. Initial costs for a number of bag filters designed for intermittent operation are given in Table 3.11. In intermittent operation, the fan is shut down every few hours by an automatic timer and the shaking device is actuated for a few minutes. The figures in Table 3.11 include the filter (cotton cloth) with $10^{\prime}$ supports, shaker motors, starters, timers, and labor for 
Table 3.10-Initial and Operating Costs for Viscous and Dry Filters (1946)

\begin{tabular}{|c|c|c|c|c|c|c|c|c|c|c|c|c|c|c|c|c|c|}
\hline \multicolumn{2}{|c|}{ Type of filter } & $\begin{array}{l}\text { Trade } \\
\text { name }\end{array}$ & Manufacturer & Size of unit & $\begin{array}{c}\text { Initial } \\
\text { cost }\end{array}$ & $\begin{array}{c}\text { Renewal } \\
\text { cost }\end{array}$ & $\begin{array}{l}\text { CFM } \\
\text { rating }\end{array}$ & $\begin{array}{l}\text { Changes } \\
\text { per } \\
\text { year }\end{array}$ & $\begin{array}{l}\text { Clean- } \\
\text { ings } \\
\text { per } \\
\text { year }\end{array}$ & $\begin{array}{c}\text { Fixed } \\
\text { charges } \\
\text { at } 1 \%\end{array}$ & $\begin{array}{c}\text { Re- } \\
\text { newal } \\
\text { of } \\
\text { media }\end{array}$ & $\begin{array}{l}\text { Labor }^{\mathrm{a}} \\
\text { for } \\
\text { replace- } \\
\text { ment }\end{array}$ & $\begin{array}{l}\text { Labor }^{2} \\
\text { for } \\
\text { clean- } \\
\text { ing }\end{array}$ & $\begin{array}{l}\text { Misc. } \\
\text { supplies }\end{array}$ & $\begin{array}{l}\text { Operat- } \\
\text { ing } \\
\text { electric } \\
\text { cost }^{\mathrm{b}}\end{array}$ & $\begin{array}{c}\text { Total } \\
\text { annual } \\
\text { cost with } \\
\text { rated CFM }\end{array}$ & $\begin{array}{c}\text { Total } \\
\text { annual } \\
\text { cost per } \\
1,000 \mathrm{CFM}\end{array}$ \\
\hline \multirow[t]{2}{*}{$\begin{array}{l}\text { Throwaway } \\
\text { or } \\
\text { renewable }\end{array}$} & Viscous & Dustop & $\begin{array}{l}\text { Owens-Corning } \\
\text { Fiberglas } \\
\text { Corp. }\end{array}$ & $20 \times 20 \times 2 "$ & $\begin{array}{r}\$ 6.00 \text { for } 2 \\
7.50 \text { for } 4\end{array}$ & $\$ 1.00$ & 800 & 4 & 12 & $\begin{array}{r}\$ 0.72 \\
0.90\end{array}$ & $\begin{array}{r}\$ 4.00 \\
4.00\end{array}$ & $\begin{array}{r}\$ 0.40 \\
0.40\end{array}$ & $\begin{array}{r}\$ 0.80 \\
0.80\end{array}$ & & $\begin{array}{r}\$ 2.28 \\
4.55\end{array}$ & $\begin{array}{l}\$ 8.20 \\
10.65\end{array}$ & $\begin{array}{r}\$ 10.25 \\
13.31\end{array}$ \\
\hline & & Renu-Vent & $\begin{array}{l}\text { American Air } \\
\text { Filter Co. }\end{array}$ & $20 \times 20 \times 3^{1 / 2^{\prime \prime}}$ & 6.00 & 1.00 & 800 & 4 & 12 & 0.72 & 4.00 & 0.40 & 0.80 & & 1.47 & 7.39 & 9.24 \\
\hline \multirow[t]{2}{*}{ Automatic } & Viscous & $\begin{array}{l}\text { Multipanel } \\
\text { MS }\end{array}$ & $\begin{array}{c}\text { American Air } \\
\text { Filter Co. }\end{array}$ & $\begin{array}{l}3^{\prime} \text { and } 4^{\prime} \text { wide } \\
5^{\prime} \text { to } 15^{\prime} \text { high }\end{array}$ & $\begin{array}{l}53.00 \text { to } \\
136.00^{\mathrm{c}}\end{array}$ & & $\begin{array}{r}3,030 \text { to } \\
23,470\end{array}$ & & $2 \mathrm{MH}$ & $\begin{array}{l}6.39^{\mathrm{c}} \text { to } \\
16.38\end{array}$ & & & $2.00^{\mathrm{C}}$ & $0.70^{\mathrm{c}}$ & $3.90^{\mathrm{c}}$ & & $\begin{array}{r}12.99 \text { to } \\
22.98\end{array}$ \\
\hline & & Model A-3 & $\begin{array}{l}\text { Dollinger } \\
\text { Corp. }\end{array}$ & $\begin{array}{l}33^{\prime \prime} \text { and } 51^{\prime \prime} \text { wide } \\
5^{\prime} \text { to } 14^{\prime} \text { high }\end{array}$ & $\begin{array}{l}50.00 \text { to } \\
140.00^{\circ}\end{array}$ & & $\begin{array}{r}3,150 \text { to } \\
21,950\end{array}$ & & $2 \mathrm{MH}$ & $\begin{array}{c}6.00^{c} \text { to } \\
16.80\end{array}$ & & & $2.00^{\mathrm{c}}$ & $0.70^{\mathrm{c}}$ & $3.90^{\mathrm{C}}$ & & $\begin{array}{r}12.60 \text { to } \\
23.40\end{array}$ \\
\hline \multirow{10}{*}{$\begin{array}{l}\text { Cleanable } \\
\text { and } \\
\text { renewable }\end{array}$} & Viscous & $M / W 2$ & $\begin{array}{l}\text { American Air } \\
\text { Filter Co. }\end{array}$ & $20 \times 20 \times 2^{\prime \prime}$ & 10.70 & & 800 & & 12 & 1.28 & & & 2.00 & 0.24 & 1.61 & 5.13 & 6.41 \\
\hline & & $M / W 4$ & $\begin{array}{l}\text { American Air } \\
\text { Filter Co. }\end{array}$ & $20 \times 20 \times 5^{\prime \prime}$ & 16.20 & & 800 & & 9 & 1.94 & & & 1.50 & 0.48 & 2.81 & 6.73 & 8.41 \\
\hline & & B-2 & Air-Maze Corp. & $20 \times 20 \times 2 "$ & 10.75 & & 800 & & 12 & 1.29 & & & 2.00 & 0.24 & 1.61 & 5.14 & 6.43 \\
\hline & & B-4 & Air-Maze Corp. & $20 \times 20 \times 4^{\prime \prime}$ & 18.09 & & 800 & & 9 & 2.17 & & & 1.50 & 0.48 & 1.87 & 6.02 & 7.53 \\
\hline & & DPV -2 & $\begin{array}{l}\text { Dollinger } \\
\text { Corp. }\end{array}$ & $20 \times 20 \times 2 "$ & 10.70 & & 800 & & 12 & 1.28 & & & 2.00 & 0.24 & 1.07 & 4.59 & 5.74 \\
\hline & & DPV -4 & $\begin{array}{l}\text { Dollinger } \\
\text { Corp. }\end{array}$ & $20 \times 20 \times 4 "$ & 18.00 & & 800 & & 9 & 2.16 & & & 1.50 & 0.48 & 1.34 & 5.48 & 6.85 \\
\hline & Dry & PL-24 & $\begin{array}{l}\text { American Air } \\
\text { Filter Co. }\end{array}$ & $24 \times 24 \times 8^{3 / 4}$ & 27.00 & 0.34 & 1,000 & 4 & 8 & 3.24 & 1.36 & 0.67 & 0.67 & & 1.34 & 7.28 & 7.28 \\
\hline & & $W K E-2$ & $\begin{array}{l}\text { Dollinger } \\
\text { Corp. }\end{array}$ & $20 \times 20 \times 2^{\prime \prime}$ & 10.70 & 2.00 & 800 & $1 / 2$ & 12 & 1.28 & 1.00 & & 1.00 & & 1.74 & 5.02 & 6.28 \\
\hline & & WKE-4 & $\begin{array}{l}\text { Dollinger } \\
\text { Corp. }\end{array}$ & $24 \times 24 \times 4^{\prime \prime}$ & 25.00 & 4.50 & 1,200 & $1 / 2$ & 12 & 3.00 & 2.25 & & 1.00 & & 1.61 & 7.86 & 6.55 \\
\hline & & Coppus & $\begin{array}{l}\text { Coppus Eng. } \\
\text { Corp. }\end{array}$ & $20 \times 20 \times 5^{3 / a^{\prime \prime}}$ & 30.00 & 7.00 & 800 & $1 / 8$ & 12 & 3.60 & 0.88 & & 1.00 & & 2.68 & 8.16 & 10.20 \\
\hline \multicolumn{18}{|c|}{$\begin{array}{l}\text { aBased on } \$ 1.00 \text { per hour labor rate. } \\
\text { basis of calculation: } 3,000 \text {-hr operation annually, power cost } \$ 0.02 / \mathrm{kwhr}, 70 \% \text { fan efficiency, } 90 \% \text { motor efficiency. } \\
\text { "Per } 1,000 \text { CFM. }\end{array}$} \\
\hline
\end{tabular}


Table 3.11-Initial Costs of Bag Filters Inside length

$\begin{array}{rccc} & \begin{array}{c}\text { Inside length } \\ \mathrm{fq} \mathrm{ft}\end{array} & \mathrm{ft} & \text { Cost } / \mathrm{sq} \mathrm{ft} \\ & & 96 & \$ \\ 940 & 4 & 384 & 1.36 \\ 3760 & 16 & 768 & 0.87 \\ 7520 & 32 & 1200 & 0.80 \\ 11750 & 50 & & 0.76\end{array}$

erection. Labor costs were calculated by assuming 16 man-hours per foot of collector length with a wage rate of $\$ 2.00$ per man-hour. Fans, fan motors and drives, electrical wiring, foundation, piping, and freight costs are excluded. Costs are given per square foot of cloth area. The ratio of CFM to cloth area will run from $2: 1$ to $4: 1$.

Table 3.12-Initial Costs for Envelope-Screen Collectors

\begin{tabular}{|c|c|c|c|c|c|c|}
\hline Area $(s q \mathrm{ft})$ & $748^{a}$ & $748^{b}$ & $4488^{\mathrm{a}}$ & $4488^{b}$ & $8976^{a}$ & $8976^{\mathrm{b}}$ \\
\hline \multicolumn{7}{|l|}{ Costs: } \\
\hline Filter & $\$ 874$ & $\$ 1088$ & $\$ 2781$ & $\$ 3340$ & $\$ 4938$ & $\$ 5460$ \\
\hline $\begin{array}{l}\text { Classifier (a baffle } \\
\text { chamber) }\end{array}$ & & & $\begin{array}{r}430 \\
\left(4^{\prime} \text { long) }\right.\end{array}$ & 430 & $\begin{array}{r}493 \\
\left(6^{\prime} \text { long }\right)\end{array}$ & 493 \\
\hline $\begin{array}{l}\text { Shaking mechanisms } \\
\text { including starter, } \\
\text { timer, damper }\end{array}$ & 134 & 840 & 134 & 1259 & 134 & 2081 \\
\hline Support & $\begin{array}{l}114 \\
\left(6^{\prime}\right)\end{array}$ & 141 & $\begin{array}{r}410 \\
\left(10^{\prime}\right)\end{array}$ & 505 & $\begin{array}{r}809 \\
\left(10^{\prime}\right)\end{array}$ & 904 \\
\hline Fan & $\begin{array}{r}113 \\
(\# 7)\end{array}$ & 113 & 813 & 813 & 1273 & 1273 \\
\hline $\mathrm{V}$ belt & 21 & 21 & 87 & 87 & 165 & 165 \\
\hline Motor & $\begin{array}{r}145 \\
(2 \mathrm{HP})\end{array}$ & 145 & $\begin{array}{r}376 \\
(15 \mathrm{HP})\end{array}$ & 376 & $\begin{array}{r}1154 \\
(40 \mathrm{HP})\end{array}$ & 1154 \\
\hline Fan pipe & 39 & 39 & 60 & 60 & 90 & 90 \\
\hline TOTAL & 1440 & 2387 & 5091 & 6870 & 9056 & 11,620 \\
\hline \multicolumn{7}{|l|}{$\begin{array}{l}\text { Freight ) } \\
\text { Foundations ) }\end{array}$} \\
\hline $\begin{array}{ll}\text { Erection } & \text { ) } \\
\text { Piping } & \text { ) } \\
\text { Wiring } & \text { ) }\end{array}$ & 1000 & 1200 & 3000 & 4000 & 6000 & 7000 \\
\hline TOTAL & 2440 & 3587 & 8091 & 10,870 & 15,056 & 18,620 \\
\hline Cost/sq ft cloth area & 3.26 & 4.80 & 1.80 & 2.42 & 1.68 & 2.08 \\
\hline
\end{tabular}


Table 3.12 gives initial costs for envelope-screen filters of both the intermittent and automatic-continuous types. An automatic filter is divided into two or more sections. Periodically, each section is shut off from the system and the bags in this section are shaken. Costs are given per square foot of cloth area. Again, the ratio of $C F M$ to area ranges between $2: 1$ and $4: 1$.

Metallurgical bag filters for fume collection are somewhat more expensive. Wool felt media are required, and filtering velocities must be relatively low to avoid plugging. A recent addition to an existing baghouse for filtering lead blast furnace fume can be cited as an example.
The addition consisted of 320 bags, $18^{\prime \prime}$ in diameter and $30^{\prime}$ long (a standard metallurgical bag). For lead blast fume, the flow rate is $250 \mathrm{CFM} / \mathrm{bag}$ and the initial cost of the installation was $\$ 1.48 /$ CFM. On the other hand, if this baghouse were used for Scotch Hearth lead furnace fume, the rate would be only $80 \mathrm{CFM} / \mathrm{bag}$, and the initial cost would be $\$ 4.62 / \mathrm{CFM}$.

(b) Operating Costs. Operating costs vary widely with the temperature and chemical composition of the gases. Fabric life ranges from a month to several years, and costs vary from about $\$ .03$ per square foot for cotton to $\$ .15$ per square foot for wool felt.

Table 3.13-Baghouse Operations - 6 Months of 1950

\begin{tabular}{|c|c|c|c|c|c|}
\hline Type of smoke & $\begin{array}{c}\text { Tons } \\
\text { recovered } \\
\text { in } 6 \text { months }\end{array}$ & $\begin{array}{l}\text { No. of } \\
\text { bags } \\
\text { replaced }\end{array}$ & $\begin{array}{l}\text { Total } \\
\text { bags in } \\
\text { house }\end{array}$ & $\begin{array}{l}\text { CFM } \\
\text { per } \\
\text { bag }\end{array}$ & $\begin{array}{l}\text { Operating cost } \\
\text { per ton of dust } \\
\text { recovered }\end{array}$ \\
\hline \multicolumn{6}{|l|}{ Lead blast } \\
\hline furnace & 616 & 68 & 342 & 197.9 & 19.92 \\
\hline \multicolumn{6}{|l|}{ Lead blast } \\
\hline furnace & 1017 & & 880 & 113.6 & 4.91 \\
\hline \multicolumn{6}{|l|}{ Lead blast } \\
\hline furnace & 2116 & 46 & 2520 & 100.0 & 8.01 \\
\hline \multicolumn{6}{|l|}{ Lead blast } \\
\hline furnace & 2819 & & 960 & 238.0 & 10.81 \\
\hline \multicolumn{6}{|l|}{ Lead blast } \\
\hline furnace & 3859 & 150 & 3532 & 59.5 & 3.20 \\
\hline Lead sinter & 897 & 210 & 910 & 89.3 & 16.07 \\
\hline Lead sinter & 3110 & 314 & 1760 & 170.0 & 14.34 \\
\hline Lead refining & 140 & 62 & 1200 & 40.8 & 20.67 \\
\hline \multicolumn{6}{|l|}{ Lead scotch } \\
\hline hearth & 18311 & 277 & 6243 & 77.9 & 3.04 \\
\hline Zinc deleading & 2130 & & 160 & 156.0 & 4.44 \\
\hline Zinc sinter & 1217 & 255 & 432 & 275.0 & 28.82 \\
\hline Cadmium & 583 & & 135 & 67.0 & 10.37 \\
\hline Cadmium & 878 & 2 & 288 & 220.0 & 2.52 \\
\hline \multicolumn{6}{|l|}{ Reverb. and } \\
\hline slag melting & 444 & 30 & 684 & 66.9 & 12.07 \\
\hline
\end{tabular}


Table 3.14-Cottrell Operations - 6 Months of 1950

A.

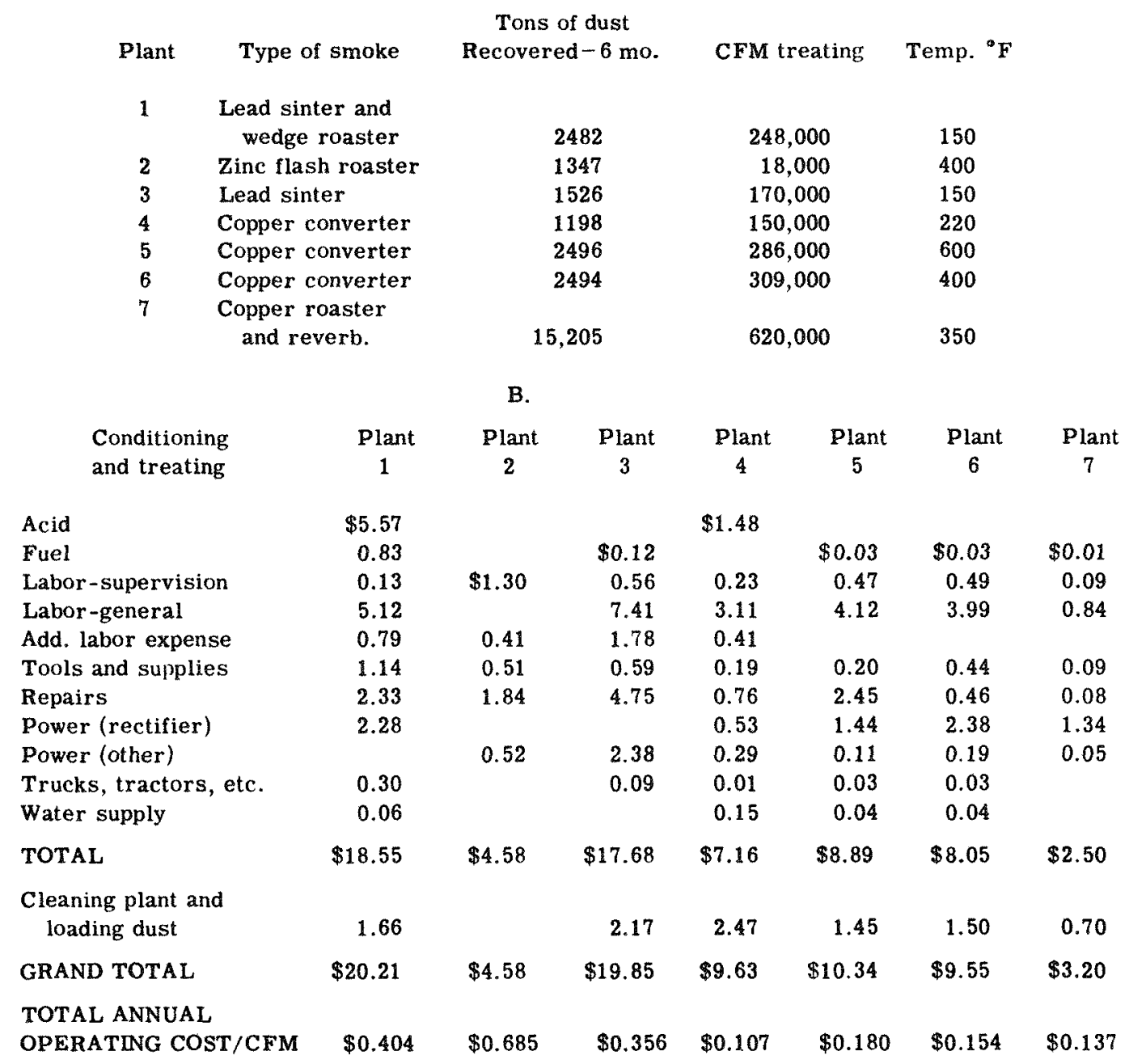

Tons of dust

Recovered -6 mo. CFM treating Temp. ${ }^{\circ} \mathrm{F}$

Mechanical and bag maintenance labor may range from 25 to 250 man-hours per year per $1000 \mathrm{CFM}$. The men should be at least semi-skilled. Power costs can be calculated from Eq. 3.2 and local power rates.

Table 3.13 gives operating costs for metallurgical bag filters treating a variety of fumes. Of the total operating costs, approximately $38 \%$ is chargeable to labor,

$25 \%$ to power, $12 \%$ to bag renewal, $7 \%$ to supervision, and the remaining $18 \%$ to fuel, tools and supplies, laundry, power shovel and engine, and car service.

\section{Electric Precipitators}

1. Cottrell Precipitators. (a) Initial costs. Costs vary widely depending on 
Table 3.15-Initial and Operating Costs for Two Stage Electric Precipitators (1946)

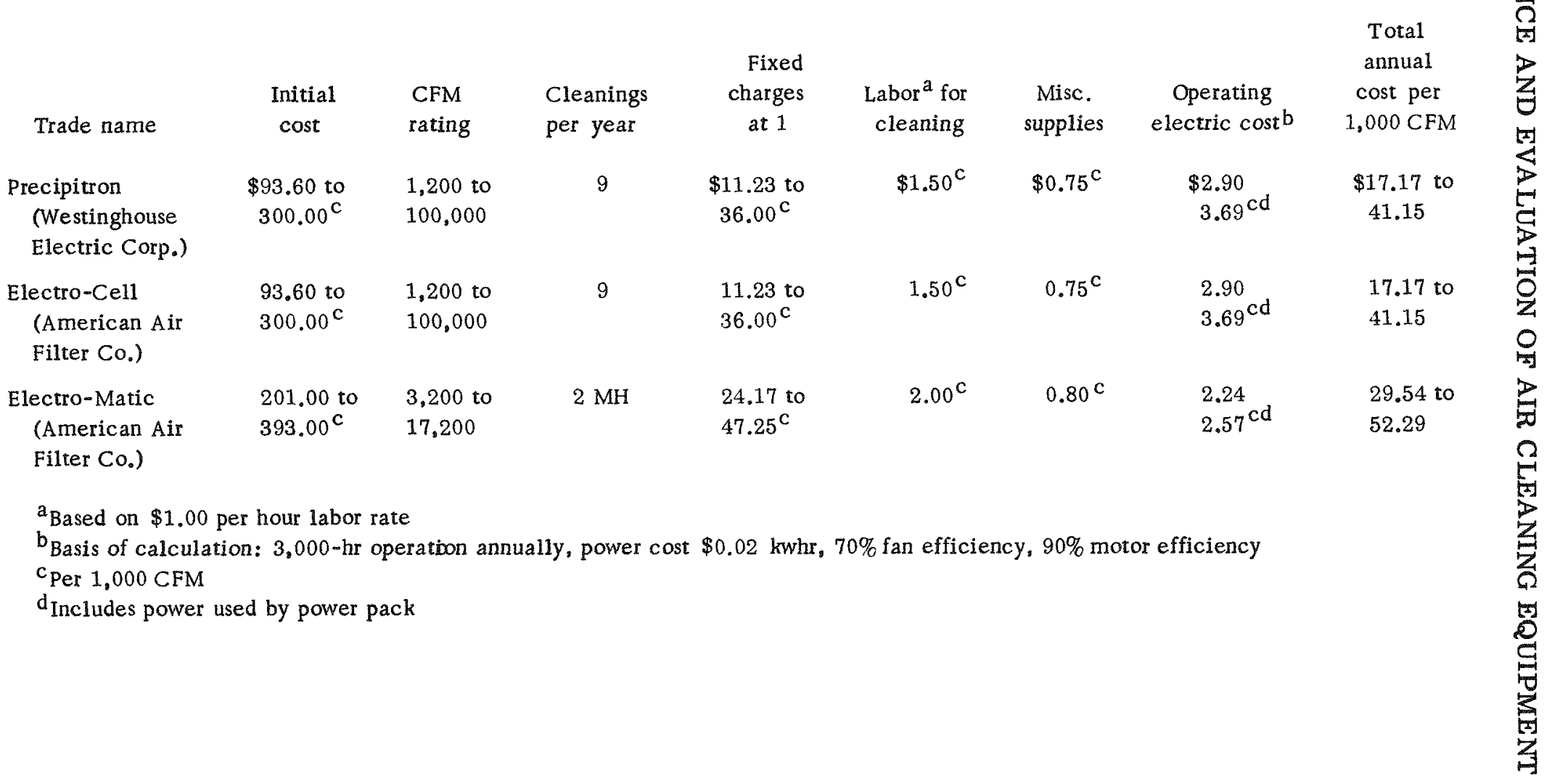


the application and on the efficiency desired. The following figures may be taken as representative:

Flyash precipitators $\$ 0.40-1.25 /$ CFM

Cement dust precipitators

Metallurgical and sulfuric acid mist precipitators

$0.80-1.50 /$ CFM

$$
<1.00 / \text { CFM }
$$

Costs for this last group are extremely variable. For example, a precipitator was built in 1948 to treat $10,000 \mathrm{CFM}$ of lead sinter smoke for the manufacture of sul- furic acid; a high precipitating efficiency was necessary. The precipitator was designed with three sections in parallel, two cells deep, or a total of six cells. The cost was $\$ 115,000$ ( $\$ 11.50 / C F M)$ including an adjacent power substation with transformers, mechanical rectifiers, and an instrument panel board.

(b) Operating Costs. Table 3.14 gives a breakdown of operating costs for Cottrells treating various metallurgical fumes.

2. Two-Stage Precipitators. Initial and operating costs for several two stage precipitators are given in Table 3.15 adapted from Carrier, Cherne, and Grant. ${ }^{34}$ 


\section{SPECIAL PROBLEMS INVOLVED IN THE CLEANING OF RADIOACTIVE AEROSOLS}

The distinguishing property of the radioactive aerosol in the field of air cleaning is its extreme toxicity. This toxicity is characterized by the emission of radiation which may be long lived, highly penetrating, and damaging to living tissue.

Large volumes of radioactive aerosols are produced in the atomic energy industry. Dispersions at a low level of radioactivity occur as (1) dusts in the mining, transporting, and storing of uranium ores, (2) dusts and mists in the drying, crushing, grinding, sieving, and packaging of the ore for subsequent chemical processing; (3) mists and fumes during the production from the ore of the brown oxide, $\mathrm{UO}_{2}$, the green salt, $\mathrm{UF}_{4}$, or the gas, $\mathrm{UF}_{6}$; and (4) fumes of uranium oxide in the fabrication of refined uranium metal to proper shape for reactor fuel, an operation requiring rolling, extruding, and machining.

Aerosols at a high level of activity are produced as (1) dusts in the cooling air discharged from the reactors at Oak Ridge and Brookhaven; the composition of the Oak Ridge particulate matter has been given as $68 \%$ atmospheric dust, cellamite, concrete, graphite, and uranium oxide and $32 \%$ solids from the demineralized water used to cool the exit air, ${ }^{39}$ and (2) mists and fumes during the dissolving of the slug casings and the subsequent chemical separation of plutonium and other products. Tests at OakRidge indicate that high level chemical processes contribute more to atmospheric contamination than the pile activities. Gaseous effluents from research laboratories have varying levels of radioactivity; in the newer laboratories, high and low level working areas are generally kept separate. Radioactive dusts of varying activities are also produced by the incineration of AEC wastes and byproducts. Table 4.1 gives the approximate activities for some aerosols produced at Oak Ridge.

In general, aerosols produced during the mining and handling of uranium (a weak emitter with a half life of about $4 \frac{1}{2}$ billion years) are not as dangerous as those generated during reactor operations and subsequent chemical processes. The extreme toxicity of the high level radioactive aerosols has given rise to a number of problems, some of which are completely new in the field of air cleaning, and none of which have been encountered heretofore on the present scale. These include:

(1) Control at the Source

(2) Design of Suitable Air Cleaning Equipment for

a) Dry aerosols at moderate temperatures

b) Wet, corrosive aerosols

c) Dry aerosols at high temperatures

(3) Disposal of Collected Particulate Matter 
(4) Monitoring of Effluent and Collector Housings

(5) Decay of Gases to Radioactive Particulate Matter

In the following discussion, we shall outline the nature of these problems and point out the general principles, with examples, on which solutions are based. A full discussion of specific equipment and techniques at the various AEC sites is given by Rossano et al. ${ }^{40}$

Table 4.1-A pproximate A ctivities for Contaminated A ir * (71)

Source

Room ventilation

Hood exhaust low-level chemical activity bearing (no gaseous activity)

Cell ventilation operating flow entrance flow

Laboratory vacuum

Hot hood and vesse1 off-gases

*This table is based on spot checks, and figures should be taken as order of magnitude.

\section{CONTROL AT THE SOURCE}

Control at the source has been defined as "the design of processes so as to minimize the initial release of particulate matter as its source."48 The principle is not new; it is applied, for example, in the ceramics industry where dry powders are wetted and mixed as a slurry to minimize the production of dust. But its application to radioactive aerosols is particularly worthwhile since (a) it provides a cleaner effluent, (b) it reduces radiation hazards involved in the maintenance of cleaning equipment or those resulting from the build-up of duct activity, (c) it permits the use of simpler and less expensive air cleaning equipment, and (d) once control has been established, it is permanent and becomes a part of the process. In general, preventing the formation of highly toxic aerosols is preferable to cleaning by secondary equipment.

The design or redesign of processes for control at the source should be based on a study of the quantity and physical characteristics of the contaminant and the manner in which it is released. ${ }^{48}$ For example, at the Oak Ridge reactor it was found that particles of uranium oxide (carrying plutonium and other fission products) were entrained by the cooling air after rupture of the slug casings. Consequently, in planning operations at the Brookhaven pile, it was decided to maintain the uranium slugs under a positive pressure in an atmosphere of helium to discourage oxidation of the uranium and to warn of impending leaks.

To minimize irradiation of dust entering with the cooling air, precleaners of $B$ and AA Fiberglas were installed at the inlet. Ducts were treated to minimize corrosion and flaking. With these measures for control at the source, cleaning of the effluent cooling air is not expected to be a serious problem at Brookhaven, and only a simple (but inefficient for particles less than 5 microns) glass fabric filter has been installed at the exit. However, this arrangement may not prove satisfactory should a period of continuous con- 
tamination occur in spite of the measures taken for slug rupture control.

\section{DESIGN OF SUITABLE AIR CLEANING EQUIPMENT}

At present, the major efforts for control of particulate contamination are being directed toward the design of suitable equipment. The most satisfactory results generally have been obtained by using combinations of the various collectors discussed in Chapter II.

Such installations should be so designed as to end treatment with the mostefficient separator possible considering the nature of the gases. To reduce mal atenance, less efficient cleaners capable of holding or disposing of most of the weight load should: be placed before the final stage. It is good practice to arrange the equipment in order of increasing efficiency.

An air cleaning installation for highly toxic aerosols should fulfill the following requirements:

(i) It should discharge clean air. The question of how clean the effluent must be is as yet unanswered; it has been suggested that for stack discharge a concentration of 30 times room tolerance is permissible for stacks over 50 feet above the highest inhabited point in the vicinity.

(ii) The equipment should require only occasional renewal and should be designed for easy maintenance. Frequent replacement or cleaning entails excessive exposure to radiation and the danger of redispersing the precipitated material.

(iii) The particulate matter should be separated in a form allowing easy disposal. The use of wet collectors, for ex- ample, poses the additional problem of disposing of volumes of contaminated liquid. Wet collection does, however, considerably reduce the danger of redispersion.

(iv) Initial and maintenance costs should be as low as possible while fulfilling the preceding three conditions. In this respect, pressure drop is generally an important consideration.

We shall review some of the equipment used at AEC sites for (a) dry aerosols at moderate temperatures, (b) corrosive, wet aerosols, and (c) dry aerosols at high temperatures, noting the measures taken to satisfy these requirements.

\section{Dry Aerosols at Moderate Temperatures}

The great majority of air cleaning problems at the various atomic energy sites involve the removal of dry particulate matter from room ventilating air and from the exhaust of laboratory hoods and dry boxes. In most cases, the cleaner used is CC-6, a cellulose-asbestos paper (Chap. II, p. 36) which is mounted in frames and installed in the ventilating ducts. This medium is very efficient (it permits penetrations of about $0.01 \%$ by methylene blue test at 4 FPM) and requires only occasional replacement when handling concentrations on the order of atmospheric air. In order to prolong the life of the paper, precleaning glass wool filters such as types B and AA (Chap. II, p. 31) are often installed; these remove large solid particles and liquid droplets.

Such filters can be placed close to the source of contamination and many can be used if necessary, each handling relative- 
ly small volumes of gases. The collected material is obtained in a concentrated form which simplifies the disposal problem. However, the CC-6 paper is expensive and not available in large quantities. In addition, there is a danger of leakage with both the precleaning and paper filters.

\section{Corrosive Wet Aerosols}

Cell ventilation gases, as well as dissolver and vessel off-gases produced during the chemical processing of the slugs, often result in corrosive, wet aerosols. At Hanford, the particulate concentrations in both streams are low (of the order of 0.2 to 0.4 grains $/ 1000 \mathrm{CF}$ or $0.7 \mathrm{mg} / \mathrm{m} 3$ ), and the particle size distributions are predominantly in the submicron range. The ventilation air is discharged at a rate of about 20,000 CFM compared with 20 to $170 \mathrm{CFM}$ for the off-gases. The off-gases contain acid vapors which may reach a volume concentration of 50 to $60 \%$. At present, the cleaning of such aerosols by filtration through composite beds of glass wool (Chap. II) seems very promising. To remove droplets and prolong the life of the glass wool it may be necessary to heat or scrub the gases before filtration. This pretreatment is particularly desirable for the dissolver gases.

An early attempt was made to clean the Hanford ventilation air by means of $\mathrm{CC}-6$ filters. The paper media worked well for four or five days, but thereafter efficiency markedly decreased because of moisture in the gases; a graded sand filter (Chap. II, p. 37) is now used for ventilation air. This sand bed is very efficient (over $99.5 \%$ by radioactivity) and will permit disposal of the collected material by eventual buri- al in situ. However, first cost was high and the filter occupies a large volume $\left(110^{\prime} \times 48^{\prime} \times 14^{\prime}\right)$.

The dissolver gases were originally scrubbed and then sent directly to the stack, but the presence of radioactive particles in the surrounding area made more efficient cleaning imperative. It is proposed to treat the gases by heating them, passing them through a silver nitrate reactor to remove radioactive iodine, and then passing them through one of the efficient composite glass wool filters.

Two-stage electric precipitators have been used for cleaning gases containing acid vapors. ${ }^{43}$ The collecting plates were attacked by the acid although they were made of stainless steel; such corrosion may cause thinning and warping of the plates with a resulting decrease in efficiency. The precipitators were more difficult to handle than filters and required periodic cleaning by a steam hose with the attendant danger of redispersion of the collected material. Electric precipitators also suffer the disadvantages of occasional arcing and power failure, both of which reduce efficiency. Thus it may be necessary to back up the precipitator with efficientglass wool and paper filters. In designing such installations, the possibility of using only a relatively inexpensive combination of filters should be investigated.

\section{Dry Aerosols at High Temperatures}

Radioactive aerosols at high temperatures are produced during the operations of the air cooled reactors at Oak Ridge and Brookhaven, and by combustion proc- 
esses for the recovery or concentration of radioactive material. In general, the treatment of such gases can be accomplished in three stages by using in order:

(1) a wet collector such as a centrifugal scrubber to cool the gases and remove most of the larger particles;

(2) an efficient dry filter such as the B and AA glass wool media to separate the greater part of the remaining particulate matter; and

(3) the highly efficient CC-6 paper. The paper should be preceded by a reheater to dry the gases.

As discussed above, Brookhaven relies on a system of control at the source to prevent contamination of its pile cooling air. At Oak Ridge, the air which leaves the reactor is cooled by spraying with demine ralized water before passing through $1 \frac{1}{2}$ inch layer of $\mathrm{B}$, another of $\mathrm{AA}$, and then through the CC-6 paper. Little maintenance is required; the precleaning filters are replaced every two years (one fourth every six months), and the paper filters last even longer. To prevent redispersion during replacement, the precleaning filters are withdrawn and submerged in water, while the paper media are sprayed with a lacquer and then removed. Much of the material collected on the filters is residual solids from the evaporated cooling water.

At the Knolls laboratories, the cooling and preliminary cleaning of the incinerator gases are accomplished, in order, by a wet baffle chamber and Pease-Anthony cyclone scrubber. The chamber, a 55 gallon drum equipped with spray nozzles directed at each of four baffles, is intended to remove particles larger than $100 \mathrm{mi}-$ crons. The final clean-up is performed by a glass wool filter followed by the CC6 paper. Some activity has been detected in the discharge gases, but in all cases it was within tolerance limits. ${ }^{72}$

\section{DISPOSAL OF COLLECTED PARTICULATE MATTER}

Once the particulate matter has been collected, the problem of its disposal becomes one of radioactive solid or liquid waste treatment. These problems are discussed in detail by Wolman and Gorman. ${ }^{73}$ It will suffice here to state that dusts and chips removed in quantities, as in ore grinding at metallurgical plants, usually are returned to supply or reconditioned for use. Combustible solid wastes like contaminated filters can be concentrated by incineration if provisions are made for decontaminating the flue gases. Other solid wastes are stored or buried in guarded areas. Liquid wastes, including wash water from wet collectors, generally are stored in tanks and, if they decay sufficiently, discharged into larger bodies of water. Research is in progress on the concentration of liquid wastes by evaporation and by biochemical methods using activated sludge.

\section{MONITORING OF EFFLUENT AND COLLECTOR HOUSINGS}

Ordinarily, during air cleaning only an occasional check of the loadings of the discharge is required. For highly toxic particulates, however, frequent monitoring of the effluent is necessary. In addition to the standard sampling devices discussed in Chapter III and elsewhere, ${ }^{52,54}$ 
a device has been developed at Brookhaven for either the continuous sampling of the air passing through a duct or for the continuous monitoring of atmospheric air. ${ }^{74}$ In this instrument (Figs. 4.1 and 4.2), a strip of filter paper is moved at a rate of 1 inch per hour across a group of small, circular apertures through which about 6 CFM of air is drawn. After collection of the dust, the paper passes in front of a beta-gamma counter and then an alpha scintillation counter; the apertures of the counters are of approximately the same size as those through which the air was drawn, so that the counting rate, after correction for decay, represents a running average of the activity of the air passing through the paper each hour. Such instruments are used for testing atmospheric air in areas around Brookhaven; it also is planned to install one for sampling the effluent from the hot laboratories.

Monitoring of the collector housing is necessary to prevent exposure to radiation of personnel cleaning the equipment or working in its vicinity. In addition, monitoring can be used to indicate the failure or overload of the equipment. At

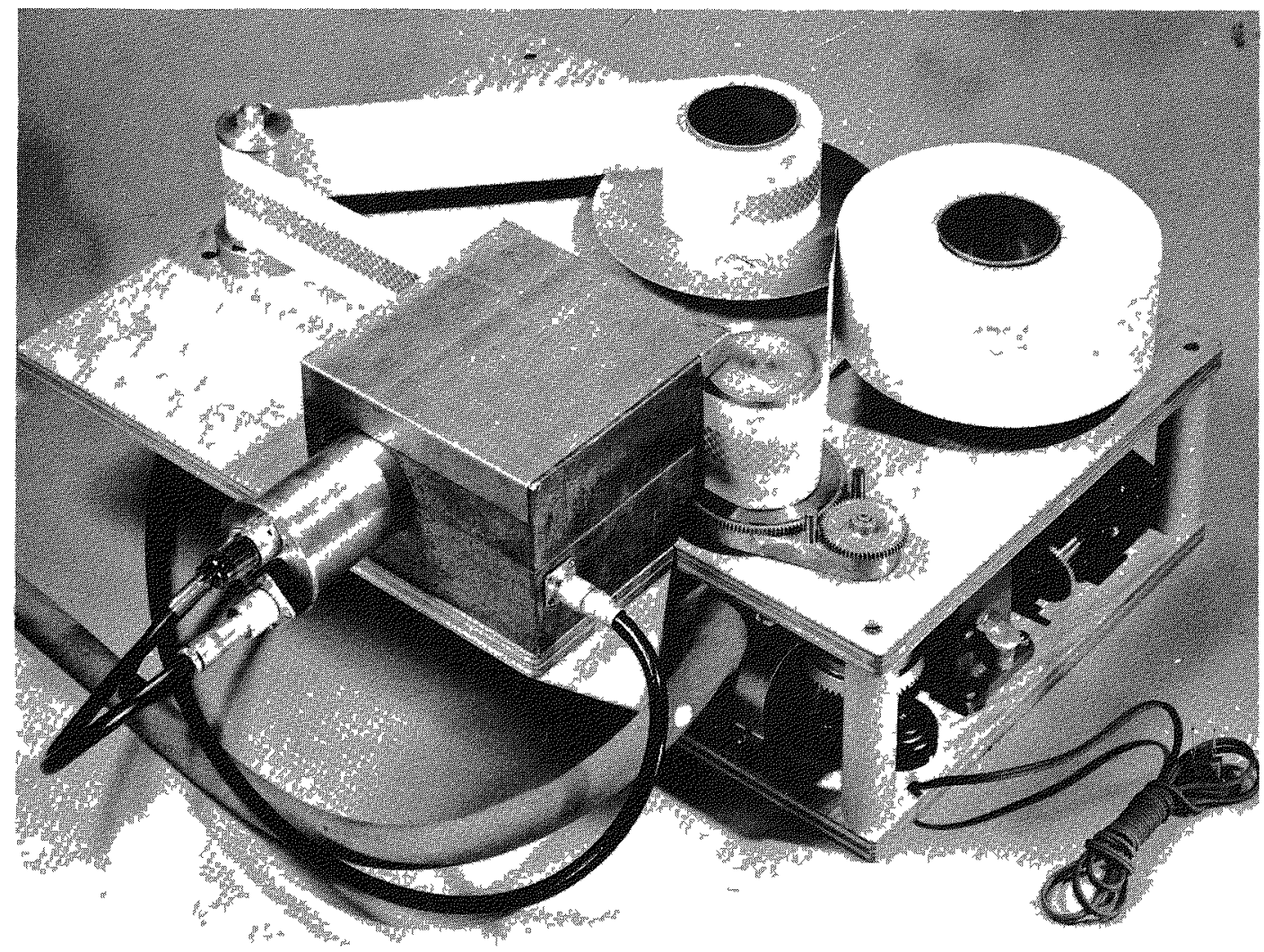

Fig. 4.1-Continuous Monitor for Radioactive Dust - Mica window beta-gamma counter is in right hand side of lead shield. Pre-amplifier for alpha scintillation counter projects from shield at right. (Brookhaven National Laboratory) 


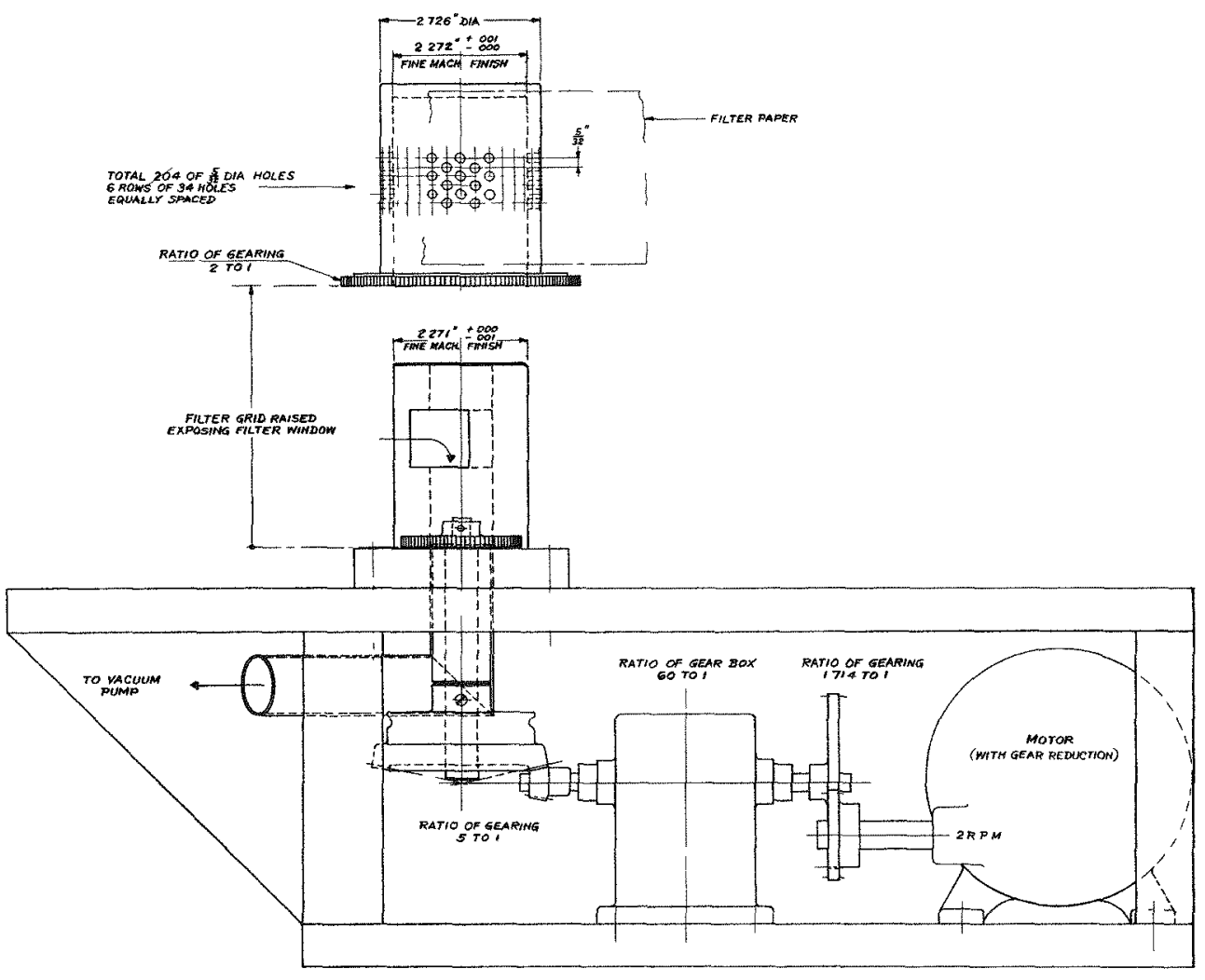

Fig. 4.2-Continuous Monitor - Details of filter paper drive and connection to air pump. (Brookhaven National Laboratory)

Oak Ridge, the activity of the filters at the pile exit is measured by an ion chamber spaced approximately 1 foot from the surface of the frames. The impulse from the instrument is amplified and recorded on a Brown electronic recorder.

\section{DECAY OF GASES TO RADIOACTIVE PARTICULATE MATTER}

Gases such as $\mathrm{Kr}^{89}, \mathrm{Kr}^{91}, \mathrm{Xe}^{140}, \mathrm{Xe}^{141}$, and, it is thought, all rare gases with a half-life of more than 3 seconds, decay to radioactive particulate matter. ${ }^{75}$ At Oak Ridge, for example, the particulate decay for 100,000 CFM of effluent cooling air is estimated as about one $\mathrm{mc} /$ day of long lived beta emitter or 5 to 10 mc/day of short lived particulate activity..$^{43}$ These particles are less than 0.2 micron when newly formed, but it is possible that they later agglomerate. Because of their formation after the filter house, the actual cleaning efficiency for the pile cooling air is less than the $99+\%$ which would be expected from the glass wool, CC-6 arrangement. Tests indicate that the efficiency is only about $91 \%$ of the potential of gross beta contamination.

The limiting rate of discharge of fission gases has not been investigated but a maximum probably exists. ${ }^{75}$ At present, the problem is not thought serious; this is fortunate since it would seem difficult to apply conventional air cleaning techniques for its solution. 


\section{NOMENCLATURE}

$A=$ cross sectional area of diffusion $\mathbf{a}, \mathbf{a}^{\prime}, \mathbf{a}^{\prime \prime}=$ constants

$A_{p}=$ projected area of particle

$B=$ width of chamber

$\mathrm{b}=$ cyclone entry width - feet

$\mathrm{C}=$ drag coefficient

$\mathrm{C}^{\prime}=$ constant

$c=$ concentration - particles unit volume

$c_{e}=$ effluent concentration

$c_{\mathfrak{i}}=$ inlet concentration

$\mathrm{D}=$ diffusivity

$D_{b}=$ diameter of target body

$\mathrm{D}_{\mathrm{c}}=$ cyclone cylinder diameter - feet

$\mathrm{D}_{\mathrm{p}}=$ diameter of particle

$\mathrm{E}=$ strength of electric field

$\mathrm{e}=$ charge on particle

$e_{\mathrm{x}}=$ cyclone exit duct diameter - feet

$\mathbf{F}=$ total energy loss - inches of water

$\mathbf{F}_{\mathrm{d}}=$ drag or resistance to motion of body in fluid

$\mathbf{F}_{\mathrm{n}}=$ total energy loss - no. inlet velocity heads

$\mathrm{H}=$ height

$\mathrm{h}=$ cyclone entry height - feet

$\mathrm{H}_{\mathrm{c}}=$ cyclone cone height - feet

$\mathrm{K}=$ constant

$k=$ cyclone entry vane factor

$\mathrm{K}_{\mathrm{me}}=$ correction factor in the StokesCunningham Law (1.72 for air)

$L=$ length or depth of bed

$L_{c}=$ cyclone cylinder height - feet

$\mathbf{M g}_{\mathrm{g}}=$ count median

$\mathrm{Mg}^{\prime}=$ mass median

$\mathrm{N}=$ Avogadro's number $=6.02 \times 10^{23}$ atoms $/ \mathrm{mol}$ $\mathrm{n}=$ inlet velocity head - inches of water

$\mathrm{N}_{\mathrm{S}}$ = number shelves in settling chamber

$\Delta \mathrm{P}=$ resistance

$Q=$ volumetric flow rate

$R=$ gas constant

$\mathbf{R}_{\mathrm{C}}=$ radius of curvature of gas stream

$\mathbf{T}=$ absolute temperature

$u=$ velocity of particle relative to that of gas

$u_{t}=$ terminal settling velocity of particle

$\mathrm{V}=$ relative velocity between gas and target body

$\mathrm{v}=$ gas velocity

$\mathrm{V}_{\mathrm{i}}=$ inlet gas velocity - feet/sec.

$V_{L}=$ tangential velocity of gas stream

$\mathrm{X}=$ length of path swept by a target body

$\mathrm{x}, \mathrm{y}, \mathrm{z}=$ constants

$\mathrm{dc} / \mathrm{dt}=$ coagulation rate - particles per unit volume per unit time

$\mathrm{dc} / \mathrm{dx}=$ concentration gradient - particles per unit volume per unit length of path

$\mathrm{dn} / \mathrm{dt}=$ diffusion rate - particles per unit time

$\sigma_{\mathrm{g}}=$ standard geometric deviation

$\lambda_{\mathrm{m}}=$ mean free path of gas molecules $(\sim 0.1$ micron for air)

$\rho=$ density of gas $(0.075 \mathrm{lbs} \mathrm{CF}$ for air at $70^{\circ} \mathrm{F}$ and $1 \mathrm{~atm}$.)

$\rho_{\mathrm{p}}=$ packing density

$\rho_{\mathrm{S}}=$ density of particle

$\mu=$ gas viscosity $(0.018 \mathrm{c} . \mathrm{p}$. for air at $70^{\circ} \mathrm{F}$ and $\left.1 \mathrm{~atm}.\right)$ 


\author{
$\eta=$ efficiency \\ $\eta_{+}=$target efficiency \\ $\mathrm{CF}=$ cubic feet \\ $\mathrm{CFM}=$ cubic feet per minute \\ $\mathrm{cm}=$ centimeters \\ FPM $=$ feet per minute \\ HP $=$ horse power
}

$$
\begin{aligned}
\mathrm{kc} & =\text { kilocycles } \\
\mathrm{kwhr} & =\text { kilowatt hour } \\
\mathrm{lpm} & =\text { liters per minute } \\
\mathrm{mc} & =\text { millicuries } \\
\mathrm{mg} & =\text { milligrams } \\
\mathrm{MMD} & =\text { mass median diameter } \\
\mathrm{m}^{3} & =\text { cubic meters } \\
\mathrm{psi} & =\text { pounds per square inch }
\end{aligned}
$$

\section{REFERENCES}

1. Gibbs, W. E., "Clouds and Smokes," Blakiston's, Philadelphia, 1924.

2. Whytlaw-Gray, R. and Patterson, H. S., "Smoke," Edward Amold, London, 1932.

3. Drinker, P. and Hatch, T., "Industrial Dust," 1st Ed., McGraw-Hill, N. Y., 1936.

4. Dalla Valle, J. M., "Micromeritics," 2nd Ed., Pitman, N. Y., 1948.

5. Lapple, C. E., "Separation of Dusts and Mists," Chemical Engineers' Handbook (Edited by Perry, J. A.), 3rd Ed., p. 1013, McGraw-Hill, N. Y., 1950.

6. "Handbook on Aerosols," A.E.C., Wash., D. C., 1950.

7. Houghton, H. G., "Spray Nozzles," Chemical Engineers' Handbook (Edited by Perry, J. H.), 3rd Ed., p. 1174, McGraw-Hîl1, N. Y., 1950.

8. Green, H. L., "Size-Frequency of Particles in Mineral Dusts," Trans. Far. Soc., 32, 1091, 1936.

9. White, H. J., Roberts, L. M., Hedberg, C. W., "Electrostatic Collection of Fly Ash," Mech. Eng., 72, 874, 1950.

10. Houghton, H. G. and Radford, W. H., "On the Measurement of Drop Size and Liquid Water Content in Fogs and Clouds," M.I.T. and Woods Hole Ocean. Inst., v. 6, No. 4, 1938.

11. Whitby, K. T., "Determination of Particle Size Distribution-Apparatus and Techniques for Flour Mill Dust," Bull., 32, Univ. of Minnesota Inst. of Tech., p. 14, 1950.

12. Vorwald, A. J. (Editor), "Pneumconiosis," p. 378, Paul B. Hoeber, Inc., N. Y., 1950.

13. Ives, J. E. et al., "Atmospheric Pollution of American Cities for the Years 1931 to 1933," Pub. Health Bull., 224, U. S. Treas. Dept., Public
Health Service, Wash., D. C., 1936.

14. Green, H., "The Effect of Non-Uniformity and Particle Shape on Average Particle Size," J. Franklin Inst., 192, 637, 1921.

15. Watson, J. H. L., "Particle Size Determinations with the Electron Microscope," Anal. Chem., 20, 576, June 1948.

16. Bell, J. R., Thomas, F. K., and Means, J. H., "Studies of Red Cell Diameter," Jour. Clin. Invest., 3, 229, 1926-7.

17. St. Clair, H. W. "Agglomeration of Smoke, Fog, or Dust Particles by Sonic Waves," Ind. Eng. Chem., 41, 2434, 1949.

18. St. Clair, H. W., Spendlove, M. J., and Potter, E. V., "Flocculation of Aerosols by Intense High Frequency Sound," U. S. Bur. Mines, R. I. 4218 , 1948.

19. Stokes, C. A., "Sonic Agglomeration of Carbon Black Aerosols," Chem. Eng. Prog., 46, 423, 1950.

20. Danser, H. W. and Neumann, E. P., "Industrial Sonic Agglomeration and Collection Systems," Ind. Eng. Chem., 41, 2439, 1949.

21. Johnstone, H. F. and Roberts, M. H., "Deposition of Aerosol Particles from Moving Gas Streams," Ind. Eng. Chem., 41, 2417, 1949.

22. Kunkel, W. F., "The Static Electrification of Dust Particles on Dispersion into a Cloud," J. App. Phys., 21, 820, 1950.

23. Brown, $\bar{C}$. E., "Studies in Dust Retention: III. Factors Involved in the Retention of Inhaled Dusts and Fumes by Man," Jour. Ind. Hyg., 13, 304, 1931.

24. Waddel, H., "The Coefficient of Resistance as a Function of Reynolds Number for Solids of Various Shapes," J. Franklin Inst., 217, 459, 1934. 
25. Rosenblatt, P. and La Mer, V. K., "Motion of a Particle in a Temperature Gradient; Thermal Repulsion as a Radiometer Phenomenon," Phys. Rev., $70,385,1946$.

26. Am. Soc. Heat. and Vent. Engrs., "Heating, Ventilating, Air Conditioning Guide 1948," p. 170, N. Y., 1948.

27. Anderson, E., "Some Factors and Principles Involved in the Separation and Collection of Dust, Mist, and Fume from Gases," Trans. Am. Inst. Chem. Engrs., 16, Part I, 77, 1924.

28. First, M. W., "Stack Gas Cleaning," Am. Ind. Hyg. Quar., 11, 209, 1950.

29. Roberts, R. T., "28 Answers to Your Dust Collection Problems," Power, 83, 346, 1939.

30. Brandt, A. D., "Washers for Particulate Matter Collection," Ind. Hyg. Quarterly, 11, 73, 1950.

31. First, M. W., Moschella, R., Silverman, L., and Berly, E., "Performance of Wet Cell Washers for Various Aerosols," Ind. Ing. Chem., 43, 1363, 1951.

32. Jones, W. P.,"Development of the Venturi Scrubber," Ind. Eng. Chem., 41, 2424, 1949.

33. Blasewitz, A. G., Carlisle, R. V., Judson, B. F., Katzer, M. F., Kurtz, E. F., Schmidt, W. C., and Weidenbaum, B., "Filtration of Radioactive aerosols by Glass Fibers," parts I and II, Hanford Works, HW-20847, Chemistry, 1951 (Unclassified).

34. Carrier, W. H., Cherne, R. E., Grant, W. A., "Modern Air Conditioning, Heating, and Ventilating," 2nd Ed., p. 220, Pitman, N. Y., 1950." "

35. Silverman, L., "Performance of Industrial Aerosol Filters," Chem. Eng. Prog., 47, No. 9, 462, Sept. 1951.

36. A. D. Little, Inc., "Investigation of Stack Gas Filtering Requirements and Development of Suitable Filters," ALI-23, Report No. 8 to Div. of Eng., U.S.A.E.C., Feb. 28, 1950.

37. Davies, C. N., "Fibrous Filters for Dust and Smoke," Proc. 9th Int. Cong. on Ind. Med., p. 14, John Wright \& Sons, Bristol, England, 1948.

38. Walton, W. H., "The Electrical Characteristics of Resin Impregnated Filters," Porton Report No. 2465, 1942.

39. Tench, F. M., "Operating Experience for Pile Filter House," Compilation of Papers Presented at the Meeting of the Stack Gas Problem Working Group, June 21 and 22, 1949, Wash. 7, Tech. Inf. Div., ORE, Oak Ridge, Tenn.
40. Rossano, A. T., Jr., Silverman, L., and First, M. W., "A Preliminary Survey of Air Cleaning Activities at Atomic Energy Commission Facilities," p. 19, Harvard University, NYO-1580, Waste Disposal, 1951.

41. Billington, N. W., Saunders, D. W., "Air Filtration," J. Inst. Heat. and Vent. Engrs., 15, 46, 1947.

42. Fielding, G. H. and Jones, E. L., "Performance of NRL-Modified Electrostatic Precipitators," Naval Research Lab., C-3240-129A/50, Wash., D. C., Nov. 20, 1950.

43. $\mathrm{Y}-12$ Plant $\mathrm{C}$ arbide and Carbon Chemicals Div., "Protective Equipment Evaluation Program Quarterly Progress Report, Oct. 1, 1949, to Dec. 31, 1949," Y-532.

44. Ibid., January 1, 1950 to March $31,1950, Y-605$. 45. Dill, R. S., "A Test Method for Air Filters," Trans, ASHVE, 44, 379, 1935.

46. American Society of Heating and Ventilating Engineers, "Standard Code for Testing and Rating Air Cleaning Devices Used in General Ventilation Work," Trans. ASHVE, 39, 229, 1933.

47. Silverman, L., First, M. W., Reichenbach, G. S., Jr., and Drinker, P., "Final Progress Report," AEC Contract No. AT-30-1-GEN-238, Feb. 1, 1950.

48. Hatch, T. F., "Measurement and Control of Radioactive Particulate Matter in AEC Operations," Compilation of Papers Presented at the Meeting of the Stack Gas Problem Working Group, June 21 and 22, 1949, Wash. 7, Tech. Inf. Div., ORE, Oak Ridge, Tenn.

49. Wilson, R., Laskin, S., and Meier, D., Design of an Oscillating Thermal Precipitator,"Univ. of Rochester Atomic Energy Project Quarterly Report, Dec. 1949.

50. Leary, J. A., "Particle Size Determination in Radioactive Aerosols by Radioautograph," Anal. Chem., 23, 850, 1951.

51. Voegtlin, C. and Hodge, H. C. (Editors), "The Pharmacology and Toxicology of Uranium Compounds," Nat. Nuc. Energy Series VI-I, p. 484, McGraw-Hill, N. Y., 1949.

52. Stokinger, H. E. and Laskin, S., "Air Pollution and the Particle-Size Toxicity Problem - II," Nucleonics, 6, No. 3, 15, 1950.

53. Green, H. L. and Watson, H. H., Medical Research Council Special Report Series, No. 199, His Majesty's Stat. Off., London, 1935. 
54. Silverman, L., "Sampling of Industrial Stacks and Effluents for Atmospheric Pollution Control," Proc. First Nat. Air Pol. Sym., Sponsored by Stanford Res. Inst., Nov. 1949.

55. Lapple, C. E., "Mist and Dust Collection in Industry and Buildings," Heating, Piping, and Air Conditioning, July, Aug., Oct., Nov., 1944; Dec. 1945; Feb. 1946.

56. American Society Mechanical Engineers, "Test Code for Dust Separating Apparatus," ASME Power Test Codes, New York, 1941.

57. Silverman, L. and Viles, F. J., Jr., "A High Volume Air Sampling and Filter Weighing Method for Certain Aerosols," Jour. Ind. Hyg. and Toxic., $30,124,1948$.

58. Gucker, F. T., Jr., Pickard, H. B., and O'Kouski, C. T., "Methods of Testing Smoke Filters," Handbook on Aerosols, p. 122, U.S.A.E.C., Wash., D. C., 1950.

59. Silverman, L. and Ege, J. F., Jr.s "A Filter Paper Method for Lead Fume Collection," Jour. Ind. Hyg. and Toxic., 25, 185, 1943.

60. Harvard University Air Cleaning Laboratory (Unpublished Data).

61. Hama, G., "Results of Tests Made on the Linderoth Aerodyne Dust Collector, Type CC," $1 / 12 / 49$, Private Communication from AEC, NYOO.

62. Harvard University Air Cleaning Laboratory, Survey of Manufacturers' Data on Air Cleaning Equipment.

63. Ekman, F. O. and Johnstone, H. F., "Collection of Aerosols in a Venturi Scrubber," Ind. Eng. Chem., 43, 1358, 1951.

64. Harris, W. B. and Breslin, A. J., "Aeroturn Study at Clifton Products," Aug. 16, 1950, Private Communication from AEC, NYOO.

65. Callinan, T. D., Lucas, R. T., and Anderson, W.
L., "Manufacture of Filter Papers from Glass Fibers," Naval Research Lab., C-3240-109750, Wash., D. C.. Oct. 24, 1950.

66. Wynn, C. S., "Preliminary Testing of Electrostatic Precipitator at Hanford Engineer Works," ARSC-11 Special, Air Reduction Sales Co., Chemical Rese arch Lab., Stamford, Conn., July 30 , 1948.

67. McCabe, L. C., "Atmospheric Pollution," Ind. Eng. Chem., 43, 89A, 1951.

68. Whitney, R. P.and Vivian, J. E. "Chemical Stack Losses and Their Recovery in the Soda Process," Paper Trade Jour. v. 109, July 6, 1939.

69. Fielding, G. H. and Jones, E. L., "Performance of NRL-Modified Electrostatic Precipitators," Naval Research Lab., C-3240-129A/50, Wash., D. C., Nov. 20, 1950.

70. Furlong, T. F., Harrison, H. C., O'Donnell, J. F.s Webb, R. P., "Removal of Radioactive Particles from Gases by the Trion Electrostatic Precipitator," K-615, EPS-X80, MIT Practice School.

71. Culler, F. L., "Plans for Attacking the Residual Atmospheric Contamination Problem at Oak Ridge National Laboratory," Compilation of Papers Presented at the Meeting of the Stack Gas Problem Working Group, June 21 and 22, 1949, Wash. 7. Tech. Inf. Div., ORE, Oak Ridge, Tenn.

72. Knolls Atomic Power Lab. Staff, "Waste Disposal Progress Report," Dec. 1950 to Feb. 1951, p.9.

73. Wolman, A. and Gorman, A. E., "Waste Materials in the United States Atomic Energy Program," Presented at N.Y.U., Jan. 12, 1950.

74. Kuper, J. B. H., Foster, E. H., and Bernstein, W., "Monitor for Radioactive Dust," Nucleonics, 6 , No. 4, 44, 1950.

75. Spiewak, K., ORNL, Personal Communication, 1951. 